\title{
Hydrogeology and Ground-Water Flow of the Drift and Platteville Aquifer System, St. Louis Park, Minnesota
}

By R.J. Lindgren

U.S. Geological Survey

Water-Resources Investigations Report 94-4204

Prepared in cooperation with the

U.S. Environmental Protection Agency

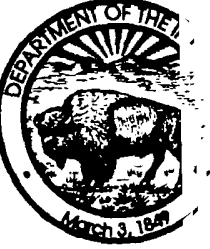

Mounds View, Minnesota 


\section{Contents}

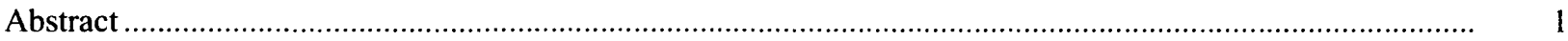

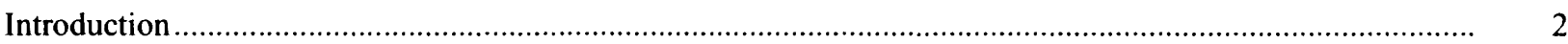

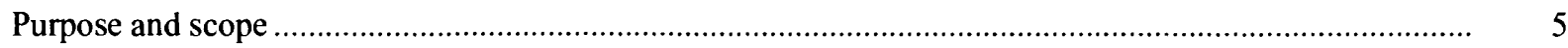

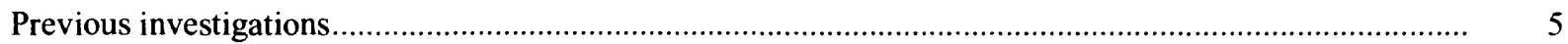

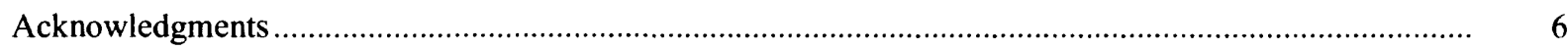

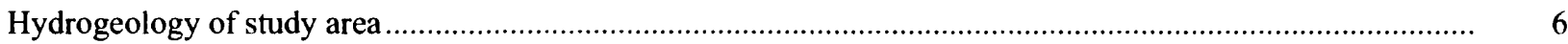

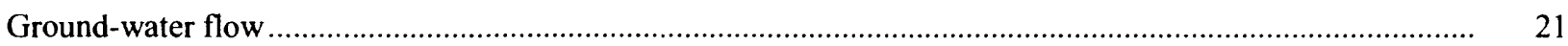

Characterization of recharge, discharge, and flow between hydrogeologic units....................................... 21

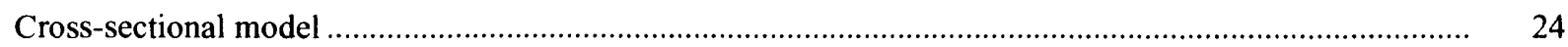

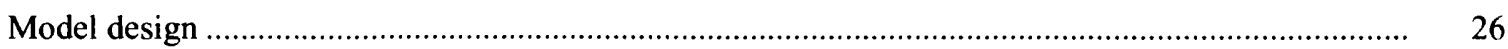

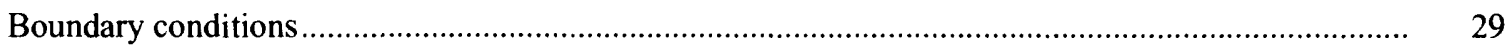

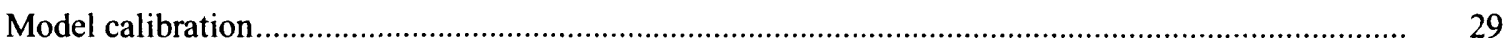

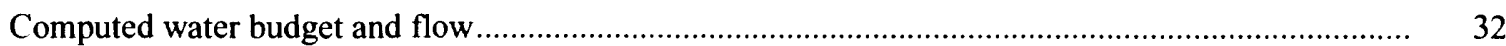

Model response to changes in representation of hydraulic properties and

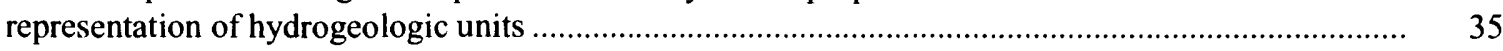

Changes in representation of hydraulic properties and recharge......................................................

Changes in representation of boundary conditions ................................................................. 43

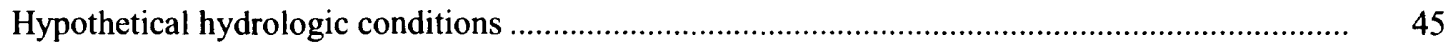

Summary of cross-sectional model simulation results ................................................................ 50

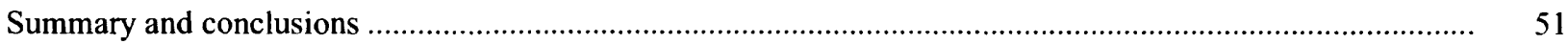

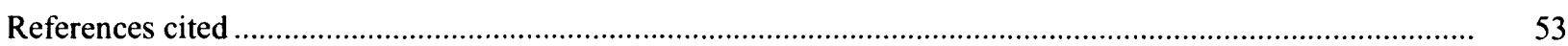

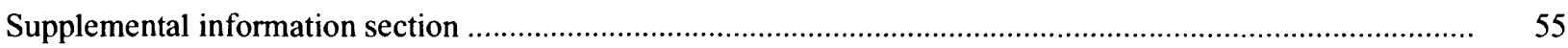

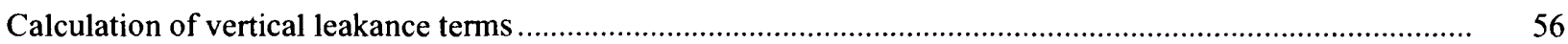

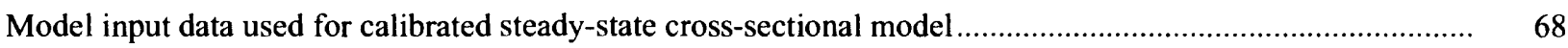

Listing 1. Input values for the BASIC package of the MODULAR program................................. 69

Listing 2. Input values for the BCF package of the MODULAR program.................................... 71

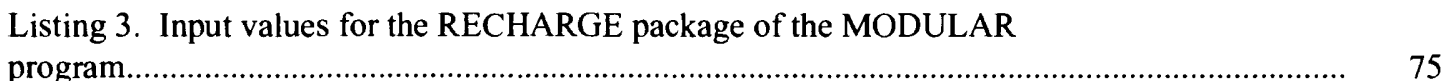

Listing 4. Input values for the SSOR package of the MODULAR program ............................... 75

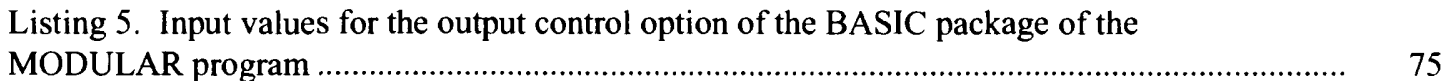

Listing 6. Input values for the main data file of the particle-tracking post-

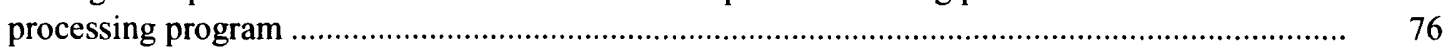

\section{Illustrations}

Figure 1-3. Maps showing:

1. Location of study area, St. Louis Park, and plant site in the Minneapolis-St. Paul Metropolitan Area, Minnesota

2. Delineated area of contamination in drift and Platteville aquifer system, St. Louis Park area, Minnesota, reported by the Minnesota Pollution Control Agency

3. Trace of hydrogeologic sections and location of plant site, bedrock valleys, and peat area, St. Louis Park area, Minnesota 


\section{Illustrations - Continued}

4. Hydrogeologic section A-A' showing hydrogeologic units, St. Louis

Park area, Minnesota

5. Hydrogeologic section B-B' showing hydrogeologic units, St. Louis Park area,

Minnesota

6-13. Maps showing:

6. Saturated thickness of upper drift aquifer, St. Louis Park area, Minnesota

7. Thickness of upper drift confining unit, St. Louis Park area, Minnesota

8. Saturated thickness of middle drift aquifer, St. Louis Park area, Minnesota

9. Thickness of lower drift confining unit. St. Louis Park area, Minnesota

10. Thickness of lower drift aquifer, St. Louis Park area, Minnesota.

11. Thickness of Platteville aquifer, St. Louis Park area, Minnesota

12. Composite potentiometric surface of the upper and middle drift aquifers,

December 1987, St. Louis Park area, Minnesota

13. Potentiometric surface of the Platteville aquifer, December 1987, St. Louis Park area, Minnesota

14. Hydrogeologic section showing hydraulic heads in December 1987 , equipotential lines, and direction of ground-water flow, St. Louis Park area, Minnesota

15-18. Diagrams showing:

15. Hydrogeologic units and cross-sectional model layers, St. Louis Park area, Minnesota

16. Path-line plot representing movement through the drift and Platteville aquifer system of recharge water derived from the infiltration of precipitation, St. Louis Park area, Minnesota

17. Path-line plot representing movement through the drift and Platteville aquifer system of water derived from boundary inflow, St. Louis Park area, Minnesota

18. Path-line plot representing movement through the drift and Platteville aquifer system of recharge water derived from the infiltration of precipitation with the vertical hydraulic conductivity of model layer 4 , representing the upper part of the lower drift confining unit, increased by a factor of 100 in the western part of the modeled cross section,

St. Louis Park area, Minnesota 


\section{Tables}

Table 1. Chart showing geologic and water-bearing characteristics of hydrogeologic

units in the St. Louis Park area, Minnesota

2. Initial and calibrated values of hydraulic properties and fluxes used in cross-sectional model of aquifer system in St. Louis Park area, Minnesota

3. Computed water budget from cross-sectional model of aquifer system in

St. Louis Park area, Minnesota.

4. Computed leakage between model layers from cross-sectional model of aquifer system in St. Louis Park area, Minnesota

5. Sensitivity of calculated hydraulic heads and fluxes to changes in values of simulated hydraulic properties and recharge for cross-sectional model of aquifer system in St. Louis Park area, Minnesota....

6. Sensitivity of calculated hydraulic heads and fluxes to changes in values of simulated vertical hydraulic conductivities for cross-sectional model of aquifer system in St. Louis Park area, Minnesota.

7. Sensitivity of calculated hydraulic heads to changes in cross-sectional model boundary conditions for aquifer system in St. Louis Park area, Minnesota

8. Changes in calculated hydraulic heads because of changes in confining unit properties represented in the cross-sectional model for aquifer system in St. Louis Park area. Minnesota.

9. Changes in calculated fluxes because of changes in confining unit properties represented in the cross-sectional model for aquifer system in St. Louis Park area, Minnesota 


\section{Conversion Factors, Vertical Datum, and Abbreviated Water Quality Units}

Multiply

foot $(\mathrm{ft})$

foot per day ( $\mathrm{ft} /$ day)

cubic foot per second $(\mathrm{ft} / \mathrm{s})$

foot squared per day $(\mathrm{ft} / \mathrm{d})$

gallon per minute (gal/min)

million gallons per day $(\mathrm{Mgal} / \mathrm{d})$

inch per year (in./yr)

foot per second $(\mathrm{ft} / \mathrm{s})$

foot per mile $(\mathrm{ft} / \mathrm{mi})$

mile (mi)

square mile (mi )
By

0.3048

.3048

.28317

.09290

.06309

.04381

25.40

30.48

.1894

1.609

2.590
To obtain

meter

meter per day

cubic meter per second

meter squared per day

liter per second

cubic meter per second

millimeter per year

centimeter per second

meter per kilom ater

kilometer

square kilometer

Chemical concentrations are given in metric units. Chemical concentrations of substances in water are given in milligrams per liter $(\mathrm{mg} / \mathrm{L})$ or micrograms per liter $(\mu \mathrm{g} / \mathrm{L})$. Milligrams per liter is a unit expressing the conc $n$ ntration of chemical constituents in solution as weight (milligrams) of solute per unit volume (liter) of water. One th susand micrograms per liter is equivalent to one milligram per liter. For concentrations less than $7,000 \mathrm{mg} / \mathrm{L}$, the n' $ı$ merical value is equivalent to concentrations in parts per million.

Sea level: In this report "sea level" refers to the National Geodetic Vertical Datum of 1929 (NGVD of 1929)—a geodetic datum derived from a general adjustment of the first-order level nets of both the United States and Canada, formerly called Sea Level Datum of 1929. 


\title{
Hydrogeology and Ground-Water Flow of the Drift and Platteville Aquifer System, St. Louis Park, Minnesota
}

\section{By R.J. Lindgren}

\begin{abstract}
Three aquifers and two confining units have been delineated within the drift underlying the area near the site of a former coal-tar distillation and wood-preserving plant in St. Louis Park, Minnesota. The hydrogeologic units of the drift, in descending order, are the upper drift aquifer, the upper drift confining unit, the middle drift aquifer, the lower drift confining unit, and the lower drift aquifer. A contamination plume consisting of coal-tar derivatives exists in the drift aquifers and in the Platteville aquifer underlying the southern part of the plant site and areas to the south and east of the plant site.

The upper drift aquifer has a maximum saturated thickness of about 25 feet. Horizontal hydraulic conductivities of the upper drift aquifer range from less than 1 to about 25 feet per day in peat areas and from about 50 to 400 feet per day in sand and gravel areas. The upper drift confining unit generally is less than 20 feet thick, with a maximum thickness of 62 feet. The saturated thickness of the middle drift aquifer generally is 20 to 30 feet in areas where the aquifer is both overlain and underlain by a confining unit. The horizontal hydraulic conductivity of the middle drift aquifer ranges from about 50 to 500 feet per day. The lower drift confining unit is as much as 50 feet thick. Modelcomputed vertical hydraulic conductivities for the upper and lower drift confining units ranged from 0.0002 to 5 feet per day. The lower drift aquifer consists of discontinuous sand and gravel deposits overlying Platteville Formation bedrock and has a maximum thickness of 20 feet where it is overlain by the lower drift confining unit.
\end{abstract}

Water in the drift aquifers and in the Platteville aquifer generally flows from the northwest to the southeast under a hydraulic gradient of about 10 feet per mile. The drift confining units and the Glenwood confining unit, when present, control the vertical movement of water through the aquifers. Discontinuities in these confining units greatly influence patterns of ground-water flow.

A numerical cross-sectional ground-water-flow model was used to test concepts of flow of ground water through the drift aquifers and the Platteville aquifer, particularly the effects of confining units and bedrock valleys on verical flow. The model has eight layers representing, in descending order: (1) the upper drift aquifer, (2) the upper drift confining unit, (3) the middle drift aquifer, (4) the upper part of the lower drift confining unit, (5) the lower part of the lower drift confining unit and lower drift aquifer, (6) the Platteville aquifer and bedrock valley deposits, (7) the St. Peter aquifer, and (8) the Prairie du Chien-Jordan aquifer. A sensitivity analysis indicated that model-calculated hydraulic heads in the drift aquifers and in the Platteville aquifer were most sensitive to variations in: (1) the horizontal hydraulic conductivities of the middle drift aquifer, (2) the transmissivities of the Platteville and St. Peter aquifers, (3) the vertical hydraulic conductivities of the lower drift confining unit and the drift material filling the bedrock valley, and (4) the vertical hydraulic conductivity of the basal St. Peter confining unit.

The model-calculated water budget indicated that recharge from infiltration of precipitation to the upper and middle drift aquifers and the upper drift confining unit accounts for about 41 percent of the total sources of water. The remaining 59 percent is from subsurface inflow from the west (through specified-head cells). About 70 percent of the outflow from the eastern model boundary was simulated as discharge from the model layers representing the Platteville aquifer and bedrock valley deposits and the St. Peter aquifer. The calibrated simulation indicated that about 99 percent of the total leakage of water from the drift aquifers and from the Platteville aquifer to the underlying St. Peter aquifer occurs through areas where the Glenwood confining unit is absent or discontinuous.

Hypothetical changes of the hydraulic properties and the extent of confining units were simulated using the calibrated steady-state model. Increasing the vertical hydraulic conductivity of model layer 4, representing the upper part of the lower drift confining unit, by a factor of 100 in the western part of the cross section resulted in decreased model-calculated leakage to the St. Peter aquifer through the bedrock valley represented in the eastern part of the cross-sectional model. A hypothetical extension of vertical hydraulic conductivities representing the Glenwood 
confining unit along the entire cross-sectional model resulted in a 98 percent reduction in the model-calculated amount of water leaking from the Platteville aquifer and bedrock valley deposits to the underlying St. Peter aquifer.

Model simulations indicate that vertical ground-water flow from the drift aquifers and from the Platteville aquifer to underlying bedrock aquifers is greatest through bedrock valleys. The convergence of flow paths near bedrock valleys and the greater volume of water moving through the valleys would likely result in both increased concentrations and greater vertical movement of contaminants in areas underlain by bedrock valleys as conpared to areas not underlain by bedrock valleys. Model results also indicate that field measurements of hydraulic head might not help locate discontinuities in confining units and additional test drilling to locate discontinuities might be necessary.

\section{Introduction}

Coal-tar derivatives from a coal-tar distillation and wood-preserving plant (hereinafter referred to as the plant site) that operated from 1918-72 have contaminated the water in several aquifers in the vicinity of St. Louis Park. Hennepin County, Minnesota (Hult and Schoenberg, 1984) (fig. 1). Water in aquifers in the drift and in the Platteville Formation has been contaminated by a complex mixture of more than 1,000 compounds. The contaminants percolated down to the water table from ponds and wetlands that received runoff and process-water from the plant. The hydrocarbonfluid phase, which is an undissolved liquid mixture of many individual coal-tar compounds, has moved vertically downward because it is denser than water. Contaminants dissolved in the ground water also have moved laterally within the drift to the southeast and downward into the underlying bedrock aquifer (Platteville aquifer). Locally, contaminants have reached another bedrock aquifer (St. Peter aquifer) through bedrock valleys where the overlying confining unit (Glenwood confining unit) has been removed by erosion.

On the basis of historical data gathered prior to 1989. the Minnesota Pollution Control Agency (MPCA) delineated an area of contamination in the drift and Platteville aquifer system (Justin Blum, Minnesota Pollution Control Agency, written commun., 1989), including the southern portion of the plant site and areas to the south and east (fig. 2). The axis of the contaminant plume is coincident with the direction of ground-water flow (east and southeast) in the drift and Platteville aquifer system near the plant site. Dissolved contaminants are carried with the ground water, but generally at a much lower velocity (Freeze and Cherry, 1979). Within the drift and Platteville aquifer system, the velocity of contaminants (polynuclear aromatic hydrocarbons (PAH) and phenolics) is estimated to be at least 20 to 25 times slower than the velocity of the ground water (Environmental Research and Technology, 1983).

Inorganic constituents in ground water in the drift and Platteville aquifer system were selected as tra^ers by Hult (1984) to evaluate transport processes because concentrations of organic contaminants in the aquifer system were very small. Data presented by Hult (1984) showed that the concentrations of several inorganic constituents near a bedrock valley southeast of the plant site were greater than those in ambient ground water. The distribution and concentration of inorganic constituents, including sodium, nitrogen species (ammonia, nitrite, and nitrate), sulfur (sulfide and sulfate), dissolved oxygen, manganese, and iron, indicate that the main body of the organic-contaminant plume is affected by downward movement of water into the St. Peter aquifer in the vicinity of bedrock valleys. The concentrations of several inorganic const tuents from the plant site decreased downgradient in the drift aquifers.

Decreased concentrations of contaminants downgradient, however, does not necessarily reflect retardation or sorption of solute. Contaminants can undergo chemical reactions, physical transformations. or be diluted by mixing (dispersion). Dispersion occurs because of mechanical mixing during fluid advection and because of molecular diffusion due to the thermalkinetic energy of the solute particles (Freeze and Cherry, 1979).

An undissolved liquid mixture of many individual coal-tar compounds, referred to as a hydrocarbon fluid phase, is in the drift beneath and near the plart site. In the saturated zone, this hydrocarbon fluid phase has moved vertically downward relative to the direction of ground-water flow because it is denser than water (Hult and Schoenberg, 1984). The vertical movement of water and of contaminants, both in hydrocarb on fluid and dissolved phases, through the drift and Platteville aquifer system is influenced by the hydraulic properties, 

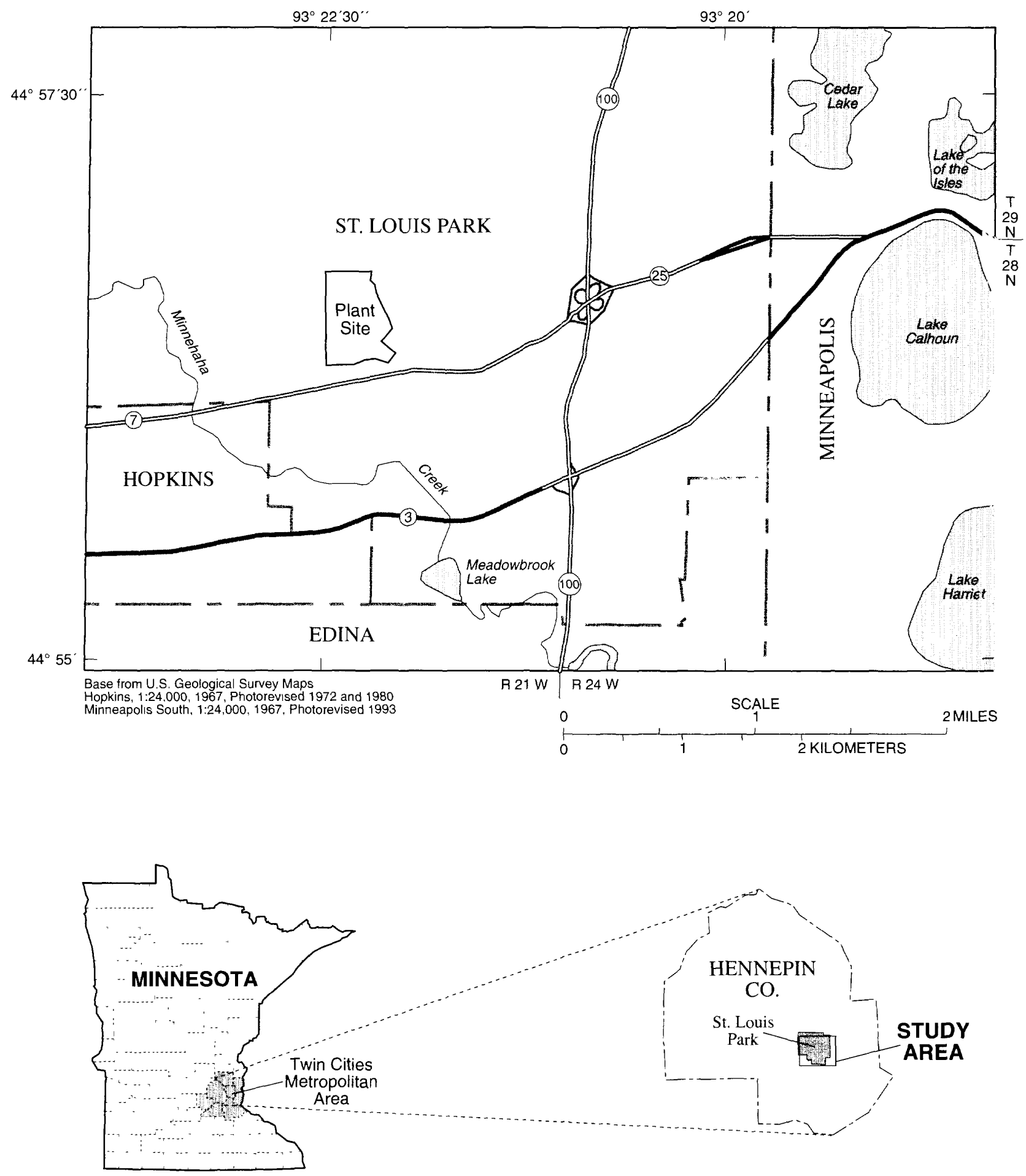

Figure 1. Location of study area, St. Louis Park, and plant site in the Minneapolis-St. Paul Metropolitan Area, Minnesota. 


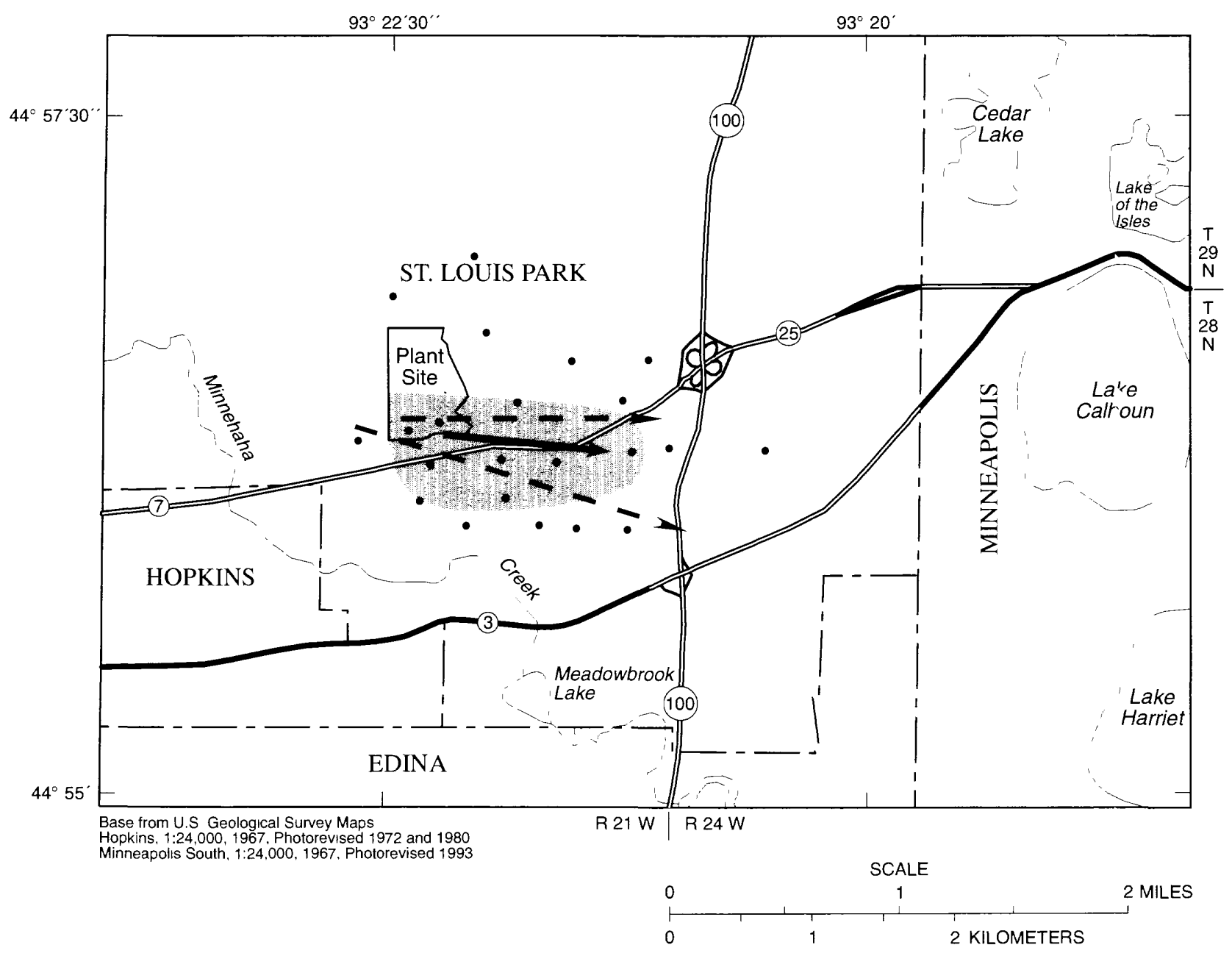

\section{EXPLANATION}

Delineated area of contamination (of at least one hydrogeologic unit) in drift and Platteville aquifer system

Axis of contaminant plume

- - Direction of ground-water flow

- Monitoring Well

Figure 2. Delineated area of contamination in drift and Platteville aquifer system, St. Louis Park area, Minnesota, reported by the Minnesota Pollution Control Agency (Justin Blum, Minnesota Pollution Control Agency, written comm. 1989). 
sorption characteristics, and presence or absence of confining units.

In 1978, the U.S. Geological Survey (USGS), in cooperation with the Minnesota Department of Health (MDH), began a study to develop a detailed understanding of the transport of coal-tar derivatives through the ground-water system in the St. Louis Park area (Hult and Schoenberg, 1984). In 1983, the USGS, in cooperation with the MPCA, began to construct. calibrate, test, and apply a numerical model to simulate ground-water flow in the St. Peter and Prairie du ChienJordan aquifers in the St. Louis Park area as part of a study of the movement of coal-tar derivatives in these aquifers (Stark and Hult, 1985). The USGS, in cooperation with the U.S. Environmental Protection Agency, began a study in 1987 to: (1) evaluate the direction and rate of movement of ground water in the St. Peter aquifer under past and current (1987-90) pumping conditions and under alternative gradientcontrol conditions and (2) develop a better understanding of hydrogeology and ground-water flow in the drift aquifers and in the Platteville aquifer. Lorenz and Stark (1990) addressed the first objective by describing ground-water flow in the St. Peter aquifer and the effects of proposed pumping scenarios. The second objective will be addressed in this report.

Previous studies completed by the U.S. Geological Survey have dealt primarily with ground-water flow and contaminant transport in the St. Peter and Prairie du Chien-Jordan aquifers and in an evaluation of possible options for remediation of contamination in those aquifers. Recent activities by local, State, and Federal regulators include the evaluation of monitoring and remedial actions in the drift aquifers and in the Platteville aquifer. The aquifer system, which consists of the drift aquifers (upper, middle, and lower), the confining units (upper and lower). and the Platteville aquifer, is hereinafter referred to as the drift and Platteville aquifer system. Because the stratigraphy and ground-water flow in the drift and Platteville aquifer system are complex, a better understanding of groundwater flow is essential to evaluate plans for additional monitoring and for implementation of gradient-control measures in the aquifers.

\section{Purpose and Scope}

This report describes the hydrogeology and groundwater flow in the drift and Platteville aquifer system near the plant site in St. Louis Park, Hennepin County. Minnesota (fig. 1). Hydrogeologic units underlying the drift aquifers and the Platteville aquifer are discussed only to the extent necessary to describe ground-water flow in the drift and Platteville aquifer system. A numerical ground-water-flow model was constructed and calibrated for steady-state conditions to represent a cross section through the study area. The model was used to test concepts of flow of ground water through the drift and Platteville aquifer system and to invest gate the effects of hydraulic properties and fluxes on hydraulic heads and ground-water flow.

\section{Previous Investigations}

Numerous studies have been made of the drift and Platteville aquifer system hydrogeology and the contamination problems in St. Louis Park. In 1933. McCarthy Well Company concluded that contamination was coming from the plant site through "several old wells being used to drain creosote away into the gro'und" (Stark and Hult. 1985, p. 6). The MDH (1938) identified nine wells in the area containing water with either a phenolic or tar-like taste. In 1946, the concentration of phenolic compounds in water from St. Louis Park well 4, located southeast of the plant site and completed in the Prairie du Chien-Jordan aquifer, was $0.1 \mathrm{mg} / \mathrm{L}$ (Hickok and Associates, 1969). Hickok and Associates (1969) reported that measurements made in 1969 indicated possible contamination of other wells and suggested additional studies be made to better evaluate the contamination problem.

A study by Sunde (1974) concluded that contamination of the St. Peter and Prairie du ChienJordan aquifers resulted from flow of contaminated water through wells connecting more than one aquifer. The MDH (1974) reported on the quality of water from private and municipal wells in the St. Louis Park area. A compilation of geological information on the St. Louis Park area was completed by Olson and others (1974). National Biocentric (1976a; 1976b) analyzed drift deposits underlying the northern part of the plant site for organic contaminants.

Barr Engineering Co. (1976 and 1977) conductet a study to assess the extent and magnitude of contamination of the ground water underlying the plant site and surrounding area. Water samples in the drift were analyzed for phenolic compounds, oil and grease, and selected inorganic constituents. Water in the $d$-ift was found to be contaminated at least 1.000 feet from the plant site. Specific remedial actions were recommended by Barr Engineering Co. to control ground-water contamination in the drift. Barr Engineering Co. (1977) concluded that the source of the low, but detectable, levels of phenolic compounds in the municipal wells completed in the Prairie du ChienJordan aquifer could not be determined from the 
available data. The MDH (1977 and 1978) measured the concentrations of polynuclear aromatic hydrocarbons (PAH) in municipal water supplies. assessed the health-risk implications, and outlined additional data needs.

Hult and Schoenberg (1984) conducted a preliminary evaluation of ground-water contamination by coal-tar derivatives in the St. Louis Park area. At least 25 ungrouted or partly cased wells in the area were considered by Hult and Schoenberg to possibly permit contaminated water from near-surface aquifers to flow into deeper bedrock aquifers along or through the well bores. Flow rates of 20 to $150 \mathrm{gal} / \mathrm{min}$ from the Platteville and St. Peter aquifers to the Prairie du ChienJordan aquifer were measured in five wells. The water was contaminated in four of the five wells. Dissolved coal-tar constituents in the drift and Platteville aquifer system had moved at least 4,000 feet downgradient to a drift-filled bedrock valley. Contaminated water with a concentration of approximately $2 \mathrm{mg} / \mathrm{L}$ dissolved organic carbon was entering the underlying St. Peter aquifer (Hult and Schoenberg, 1984, p. 1). Chemical analyses of water pumped from observation wells indicated soluble, low-molecular-weight compounds were moving preferentially through the drift and Platteville aquifer system.

Stark and Hult (1985) developed a numerical threedimensional ground-water-flow model of the Prairie du Chien-Jordan aquifer and overlying hydrogeologic units, including glacial deposits in bedrock valleys, the St. Peter aquifer, and the basal confining unit of the St. Peter Sandstone, in the St. Louis Park area. The model was used to evaluate the movement of coal-tar derivatives from the plant site. The model was also used to investigate the effects of cones of impression (locally persistent mounds in the potentiometric surface near wells) created by water introduced into the Prairie du Chien-Jordan aquifer through wells open to more than one aquifer. The simulations indicated that cones of impression could have a significant effect on the transport of contaminants in the Prairie du Chien-Jordan aquifer. The simulations also were used to investigate the response of hydraulic heads in the Prairie du ChienJordan aquifer to pumping from wells located upgradient from the plant site. Stark and Hult concluded that local hydraulic gradients would be altered to the extent that contaminants would move from the area of the plant site to these wells (Stark and Hult, 1985 , p. 45). Simulations of a gradient-control plan using five discharge wells indicated that the actions would be effective in limiting the extent of the contaminated plume in the Prairie du Chien-Jordan aquifer. The model-calculated hydraulic heads, however. were sensitive to changes in withdrawal rates at wells not intended to be under the control of the plan. Management of discharge from these wells also would be important to the overall effectiveness of the remedialaction plan.

Lorenz and Stark (1990) used a numerical model of ground-water flow to: (1) simulate ground-water flow in the Prairie du Chien-Jordan and St. Peter aq'ifers in St. Louis Park. Minnesota, (2) test hypotheses about the movement of ground water contaminated with coal-tar derivatives, and (3) simulate alternatives for reducing the downgradient movement of contamination in the St. Peter aquifer. The model also was used to simulate the effects of multiaquifer wells open to both the 5 . Peter and Prairie du Chien-Jordan aquifers. The sim ulations indicated that sustained pumping from these multiaquifer wells would cause cones of depression in both aquifers and could limit the downgradien ${ }^{+}$ migration of contaminants in the St. Peter aquifer and in the Prairie du Chien-Jordan aquifer. Model simulations also indicated that areal differences in vertical leakage to the St. Peter aquifer, which may exist in bedrock valleys, are not likely to significantly affect the general patterns of ground-water flow.

\section{Acknowledgments}

Appreciation is expressed to the staff of the Minnesota Pollution Control Agency, in partic 'lar to Justin Blum. for guidance and assistance with data compilation and water-level measurements and for valuable discussions of site history.

\section{Hydrogeology of Study Area}

During the Pleistocene Epoch four continental glaciers covered the bedrock surface in east-central Minnesota with drift. The thickness of the drift in the study area ranges from about 70 feet, under the plant site, to about 125 feet, in bedrock valleys. The vertical and horizontal distribution of aquifers and confining units within the drift is highly variable and complex. Hydrogeologic units in the drift defined for this study are shown in table 1 .

The study area is underlain by a thick sequence of sedimentary rocks (as much as $1,000 \mathrm{ft}$ ), ranging in geologic age from the Precambrian Period to the Ordovician Period. The sedimentary rocks were deposited in a north-south trending trough in the Precambrian rock surface. The deepest part of the trough, commonly referred to as the Twin Citios Artesian Basin, lies directly beneath the Minneapolis-St. Paul Metropolitan Area. The sedimentary roc's $s$ in the 


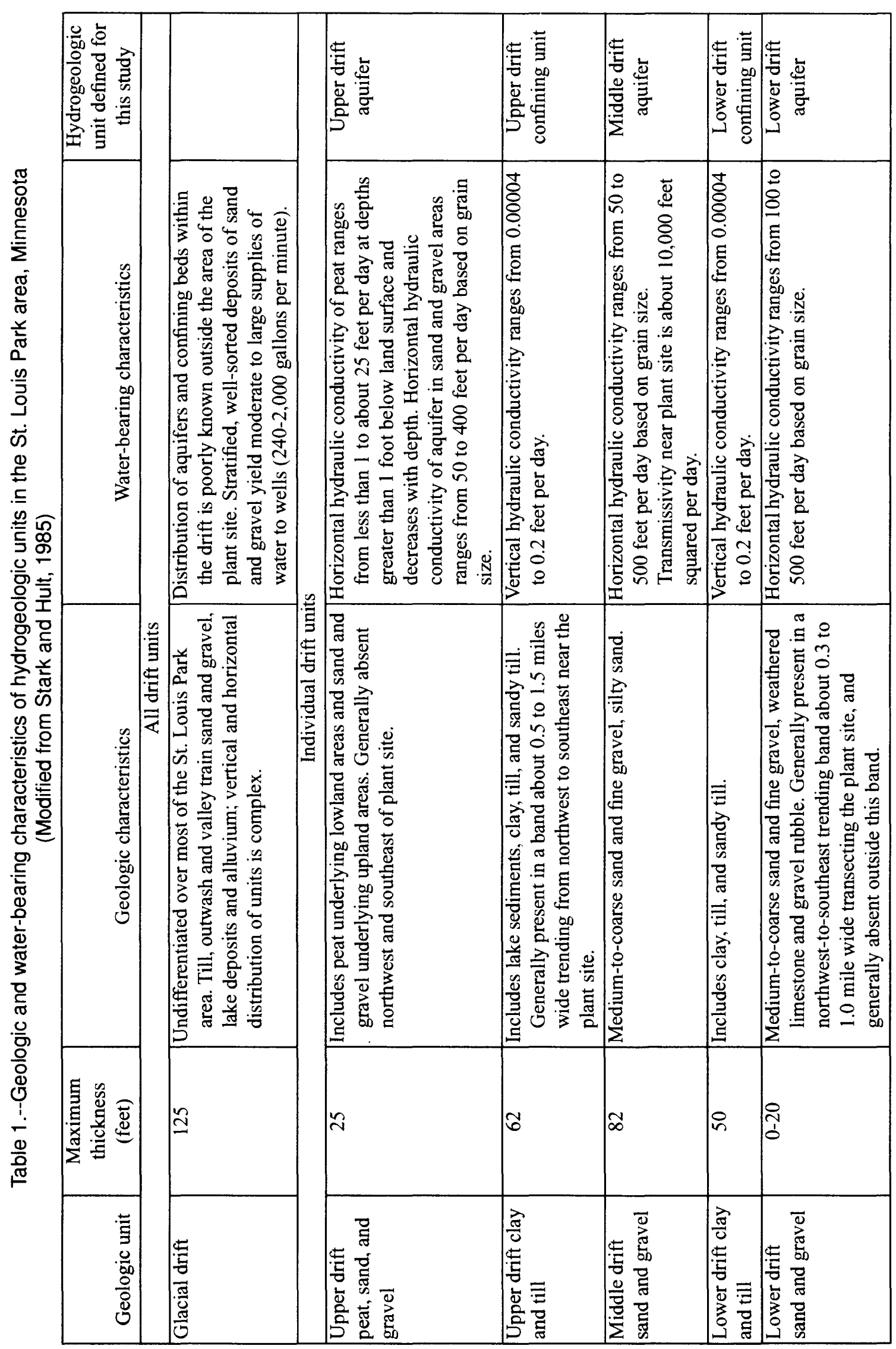




\begin{tabular}{|c|c|c|c|c|c|c|c|}
\hline 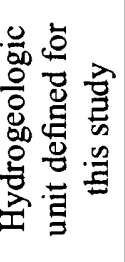 & 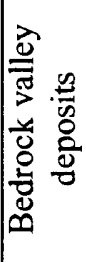 & & 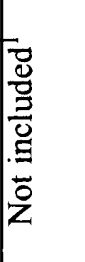 & 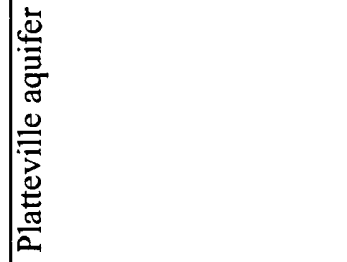 & 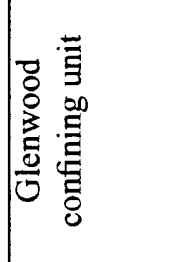 & 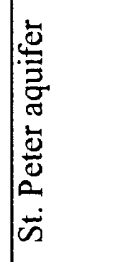 & 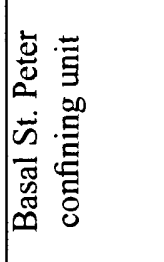 \\
\hline 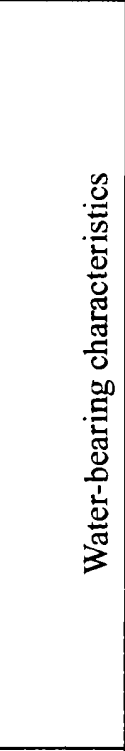 & 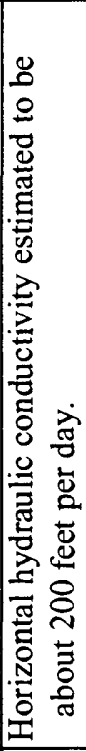 & & 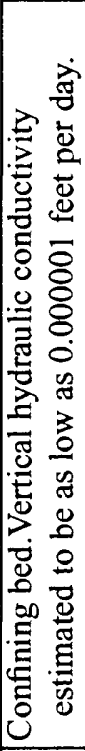 & 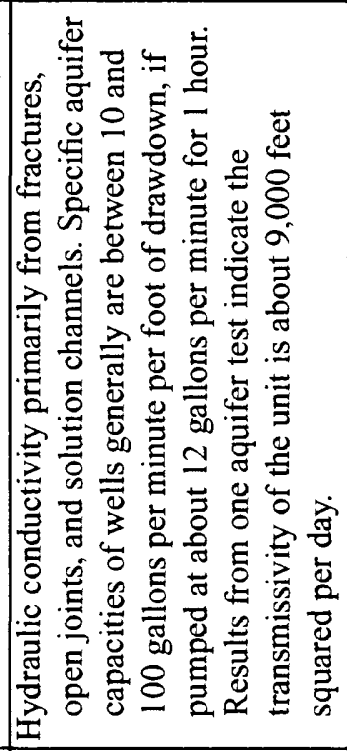 & 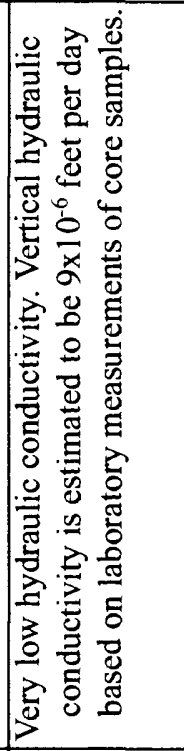 & 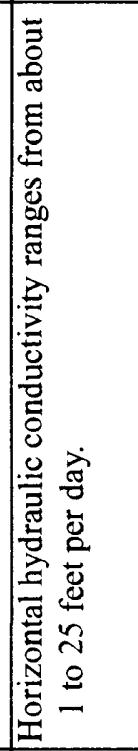 & 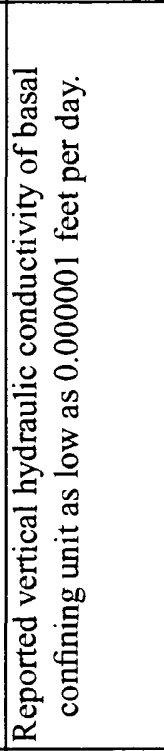 \\
\hline 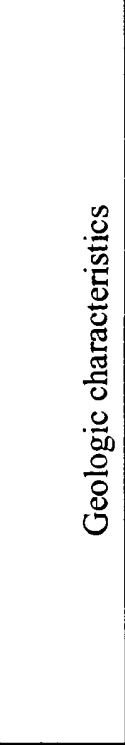 & 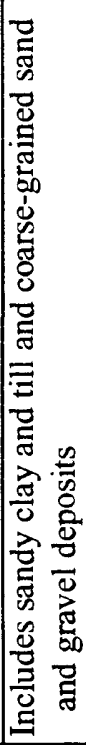 & 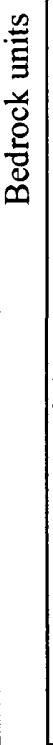 & 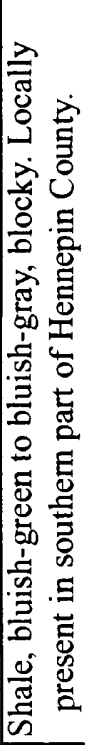 & 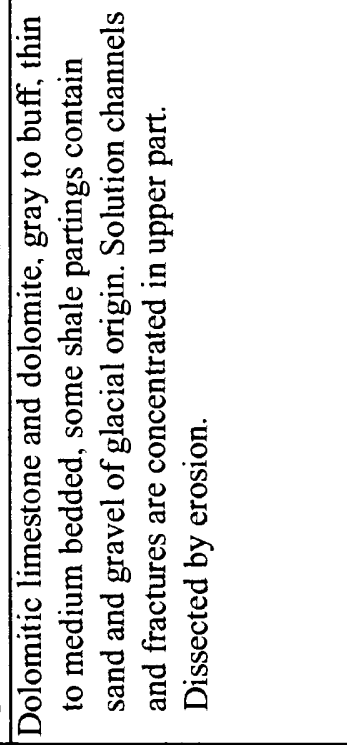 & 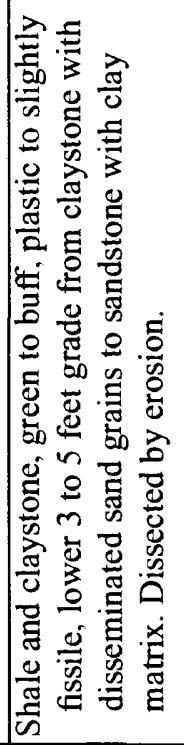 & 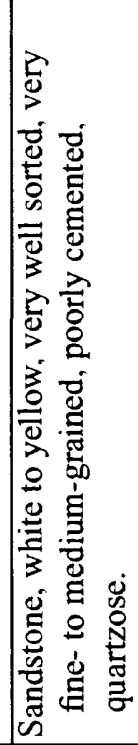 & 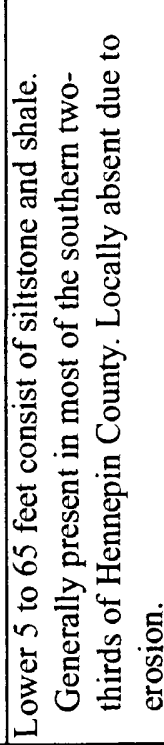 \\
\hline 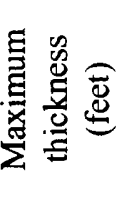 & m & & $a$ & I & $\simeq$ & $\stackrel{m}{m}$ & 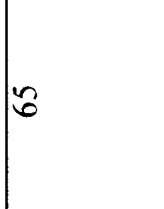 \\
\hline 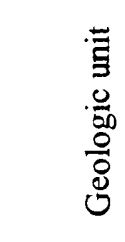 & 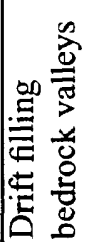 & & 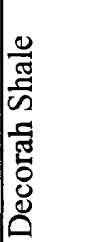 & 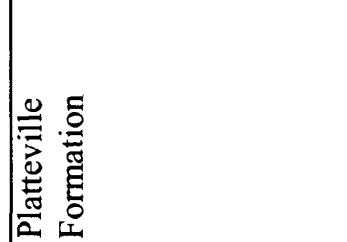 & 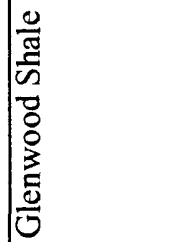 & 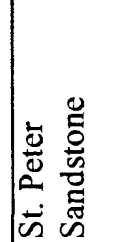 & \\
\hline
\end{tabular}




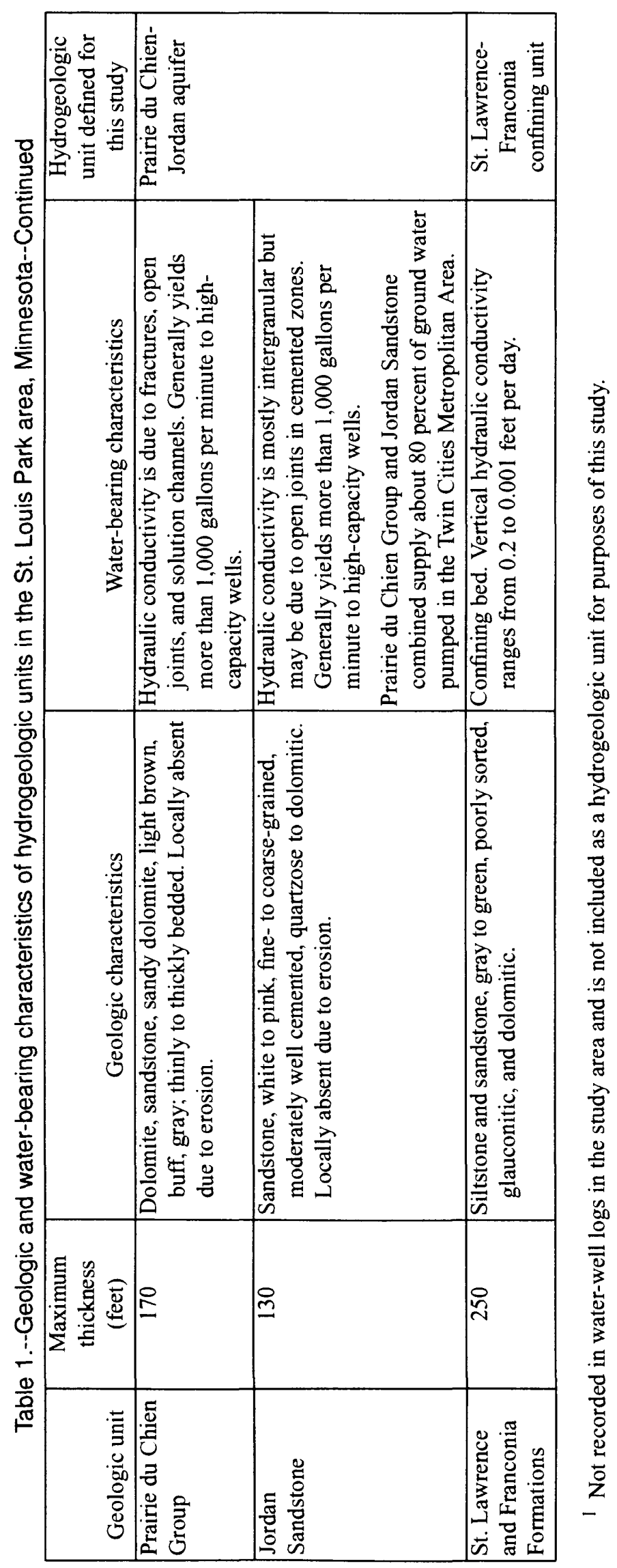


basin, with the exception of the Hinckley Sandstone (Precambrian), were deposited in Cambrian and Ordovician seas. Sedimentary rocks from Middle Ordovician Period to Quaternary Period are absent. The bedrock surface in the study area is dissected by valleys that were formed either from the Middle Ordovician Period to the Quaternary Period or during the interglacial periods (Norvitch and others, 1974) (fig. 3). Descriptions of the bedrock and hydrogeologic units discussed in this report and their positions in the geologic column are shown in figure 4 .

The detailed stratigraphy of the drift is complex. Barr Engineering Co. $(1976,1977)$ and Hult and Schoenberg (1984) identified three areally persistent units of hydrogeologic significance: (1) the middle drift aquifer of glacial sand and gravel; (2) the upper drift confining unit, an overlying confining bed of lake deposits and till; and (3) an underlying basal drift complex of till, outwash, valley-fill deposits, and deeply weathered bedrock. Hult and Schoenberg (1984) described a fourth unit, the upper drift aquifer, as being poorly defined and discontinuous in the study area.

Three aquifers and two confining units were delineated in this study. The vertical distribution of aquifers and confining units is illustrated for two hydrogeologic sections (figs. 4 and 5). The drift aquifers defined in the study area are the upper drift, middle drift, and lower drift aquifers. The term combined drift aquifer refers to the areas where drift confining units are absent (figs. 4 and 5). The drift confining units defined in the study area are the upper drift confining unit and the lower drift confining unit. The upper drift aquifer, middle drift aquifer, and upper drift confining unit discussed in this report correspond to hydrogeologic units identified by Barr Engineering Co. (1976, 1977) and Hult and Schoenberg (1984). The lower drift confining unit and lower drift aquifer defined in this report comprise the basal drift complex identified in those two reports.

The upper drift aquifer ranges in composition from peat, underlying the plant site and the area to the south near Minnehaha Creek, to sand and gravel, underlying most of the study area (fig. 6). The aquifer generally is absent northwest of the plant site and in the southeast part of the study area where till is present at the land surface. The aquifer is under water-table (unconfined) conditions throughout the study area. At some locations the surficial sand and gravel is unsaturated (fig. 6). The saturated thickness of the upper drift aquifer is as much as $25 \mathrm{ft}$ (fig. 6). Based on the grain-size distribution, the horizontal hydraulic conductivity of the aquifer in areas of sand and gravel ranges from about 50 to $400 \mathrm{ft} / \mathrm{d}$.
Horizontal hydraulic conductivity values for feat decrease with increasing depth below the land surface. Reported values range from less than 1 to abo' $25 \mathrm{ft} / \mathrm{d}$ at depths greater than about $1 \mathrm{ft}$. Furthermore, the vertical hydraulic conductivity of peat generally is considered to be much less (by orders of magnitude) than the horizontal hydraulic conductivity (Tom Gullett, Minnesota Department of Natural Resources, written commun., 1990).

The upper drift aquifer is underlain by the upper drift confining unit, a discontinuous confining bed composed of lake deposits, silty to sandy clay, and till. The upper drift aquifer is continuous with the underlying middle drift aquifer where the upper drift confining unit is absent. The upper drift confining unit generally is present in a band about 0.5 - to 1.5 -miles wide trending from the northwest to the southeast in the study area and underlies all but the southeast corner of the plant site (fig. 7). The thickness of the confining unit generally is less than $20 \mathrm{ft}$. but is as much as $62 \mathrm{ft}$ where it is present at the land surface. Norvitch and others (1974) report values of vertical hydraulic conductivity for clays and till with varying amounts of sand ranging from 0.00004 to $0.2 \mathrm{ft} / \mathrm{d}$. Hult and Schoenberg (1984) repor that till has a vertical hydraulic conductivity as low as 0.0009 $\mathrm{ft} / \mathrm{d}$ near the plant site.

The saturated thickness of the middle drift aquifer ranges from 4 to $82 \mathrm{ft}$ (fig. 8). Sand and gravel extends from land surface to the base of the middle drift aquifer where the upper drift confining unit is absent (figs. 6 and 7). The greatest saturated thicknesses are south and east of the plant site where the middle drift aquifer is under unconfined conditions. The aquifer is under confined conditions in a northwest-to-southeast trending band where the upper drift confining unit is present. The aquifer is under unconfined conditions to the south and east where the overlying upper drift confining unit is absent. The saturated thickness generally is 20 to $30 \mathrm{ft}$ in areas where the aquifer is both overlain and underlain by a confining unit. The composition of the anuifer varies from silty sand to medium-to-coarse grained sand and fine gravel. Hult and Schoenberg (1984) report the middle drift aquifer has a transmissivity as high as about $10,000 \mathrm{ft}^{2} / \mathrm{d}$. Based on the grain-size distribut'on, the horizontal hydraulic conductivity of the aquifer ranges from about 50 to $500 \mathrm{ft} / \mathrm{d}$.

The middle drift aquifer is underlain by the lasal drift complex, which consists of till, outwash, valle:'-fill deposits, and deeply weathered bedrock. The tasal drift complex can be partitioned into: (1) an upper unit that is predominantly sandy to silty clay and till, hereinafter referred to as the upper part of the lower drift confining 


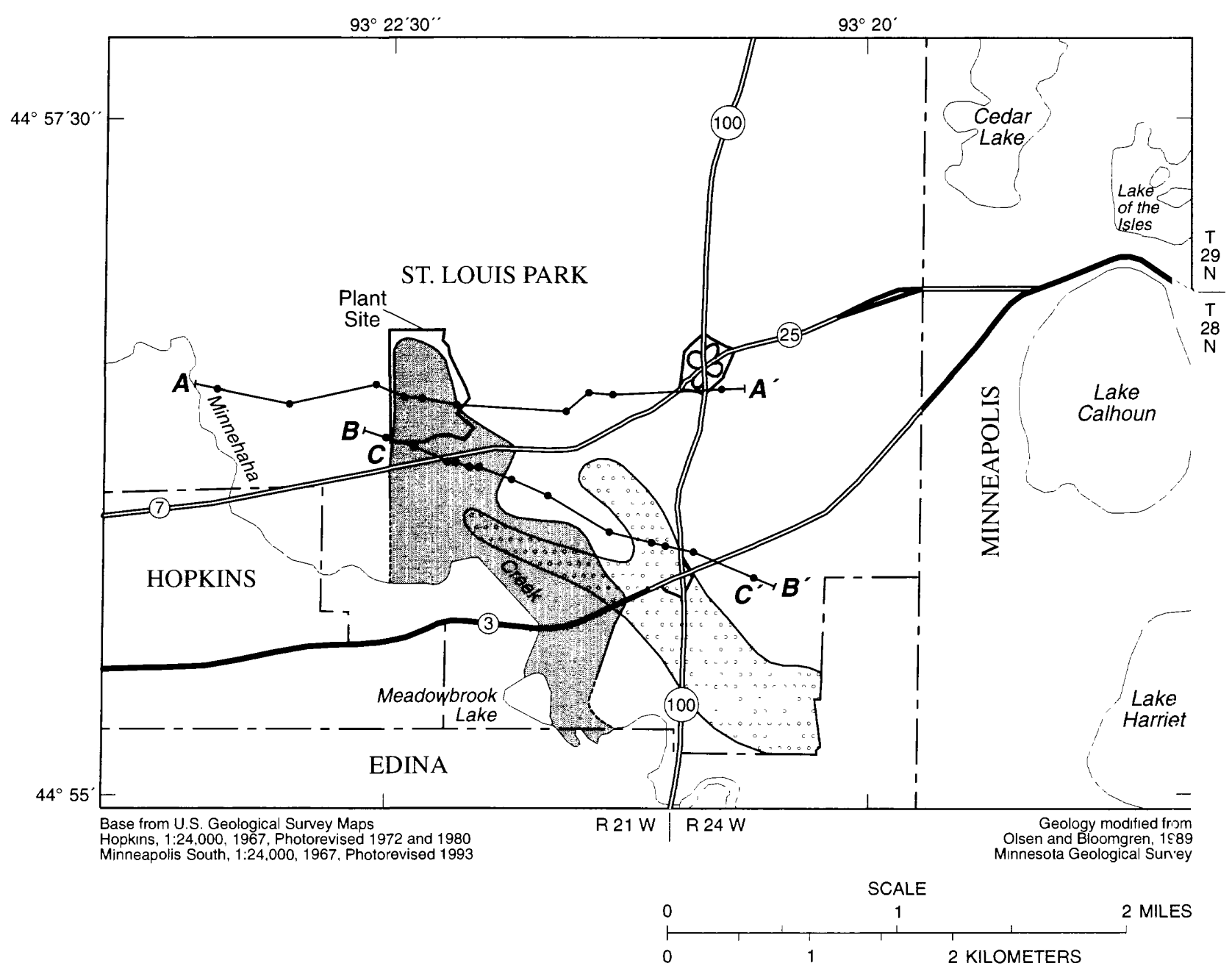

EXPLANATION

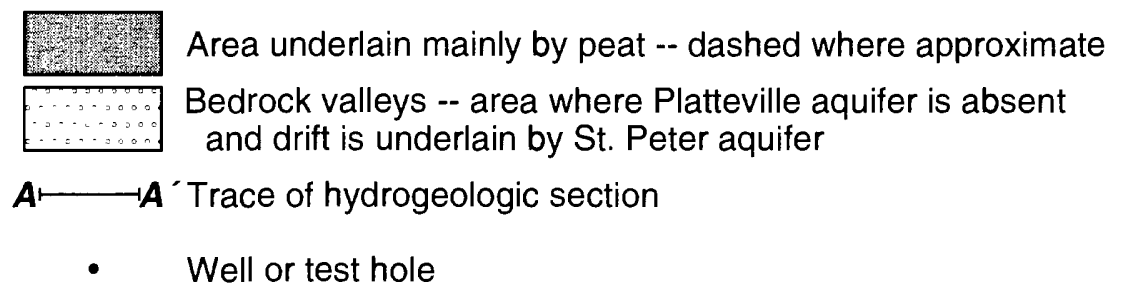

Figure 3. Trace of hydrogeologic sections and location of plant site, bedrock valleys, and peat area, St. Louis Park area, Minnesota. 


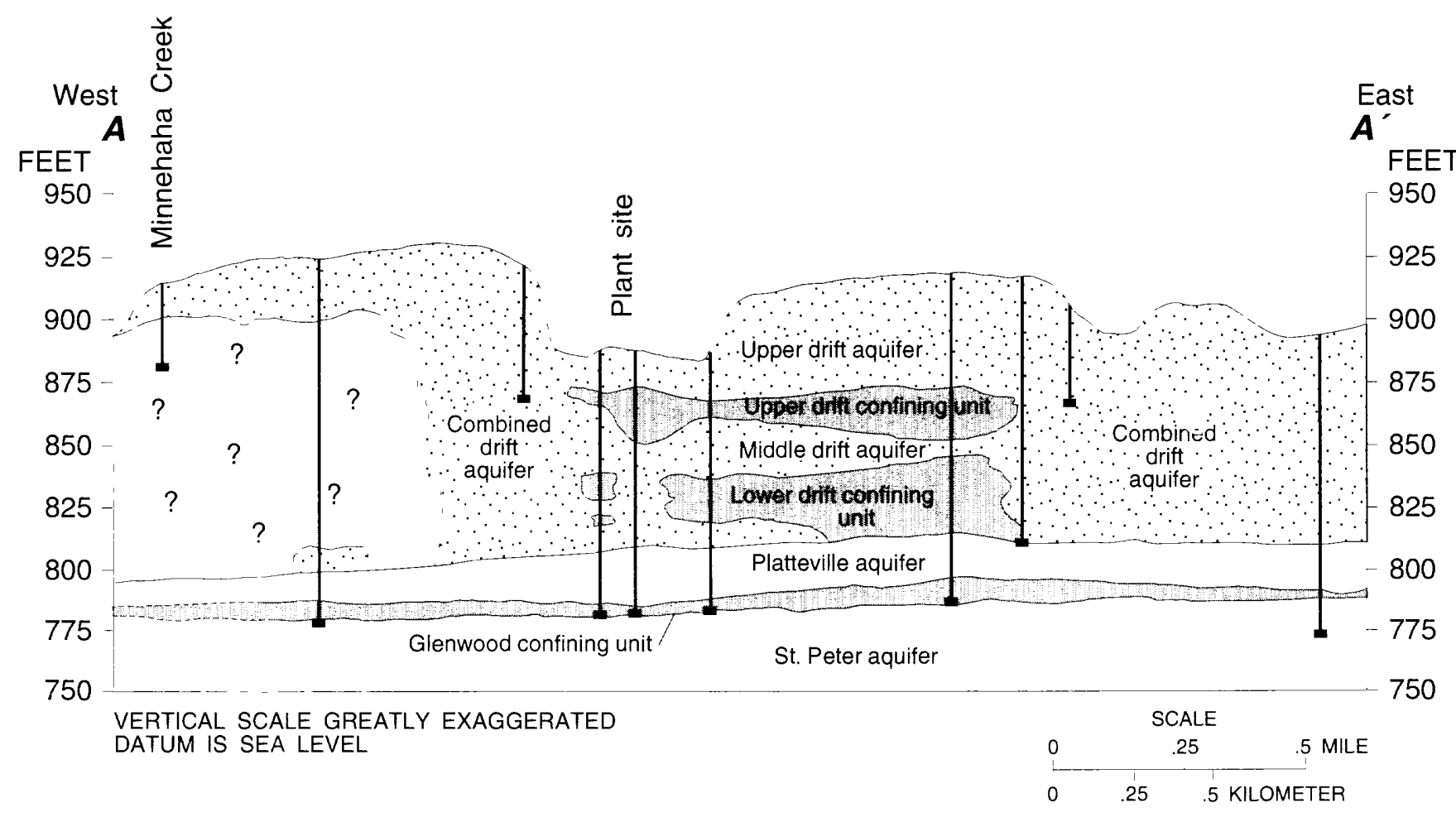

\section{EXPLANATION}

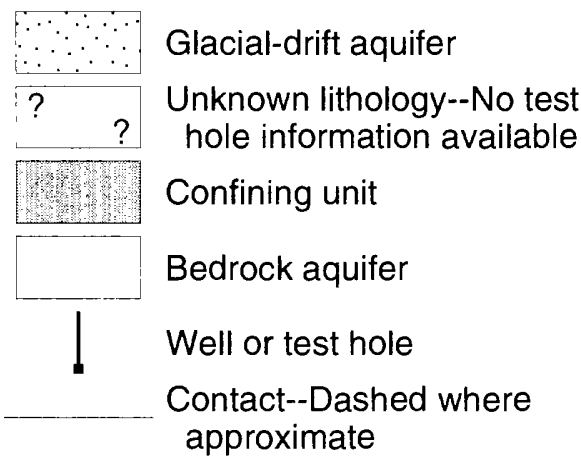

Figure 4. Hydrogeologic section A-A' showing hydrogeologic units, St. Louis Park area, Minnesota (trace of sections shown in figure 3 ). 
$\boldsymbol{B}$

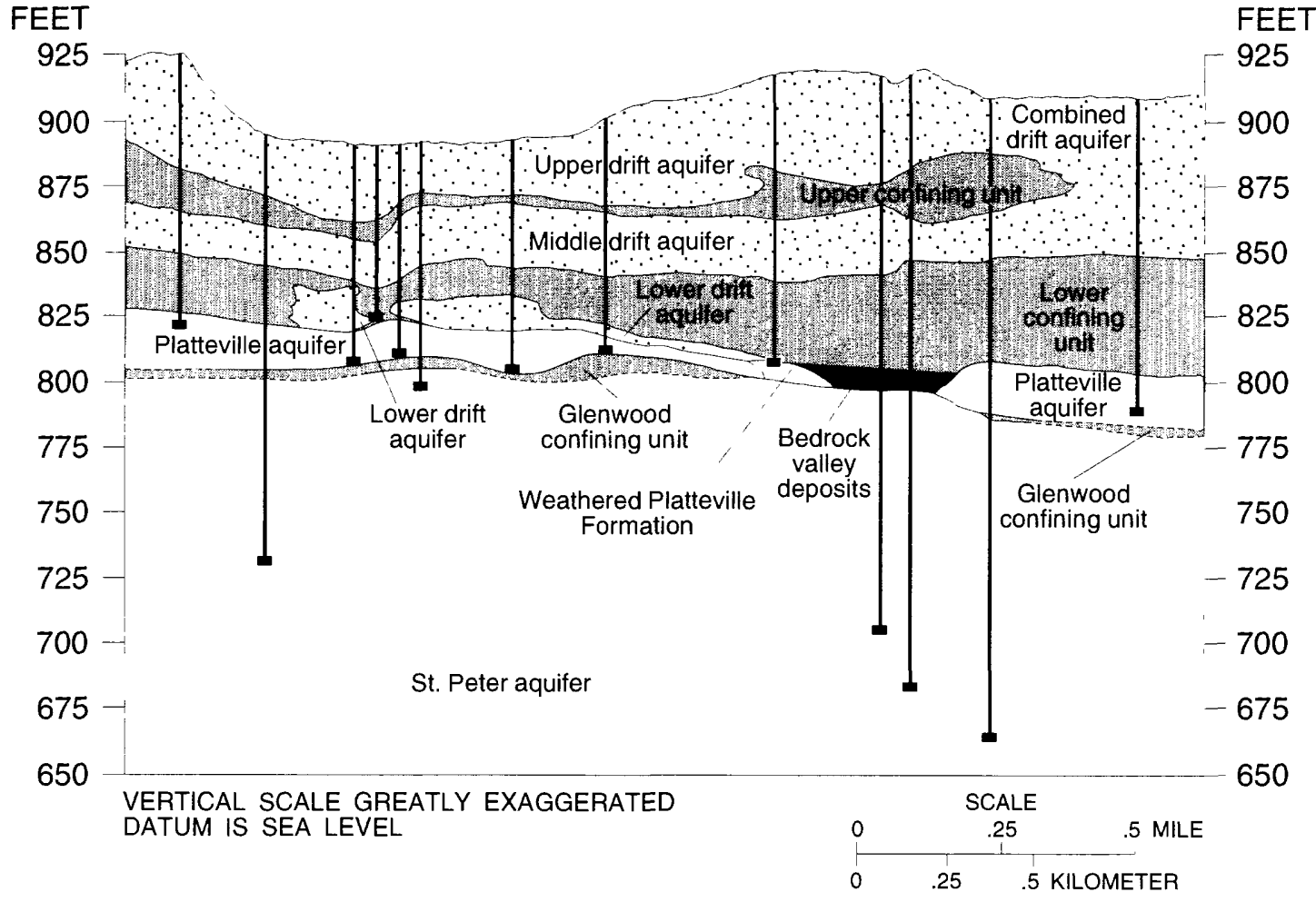

\section{EXPLANATION}

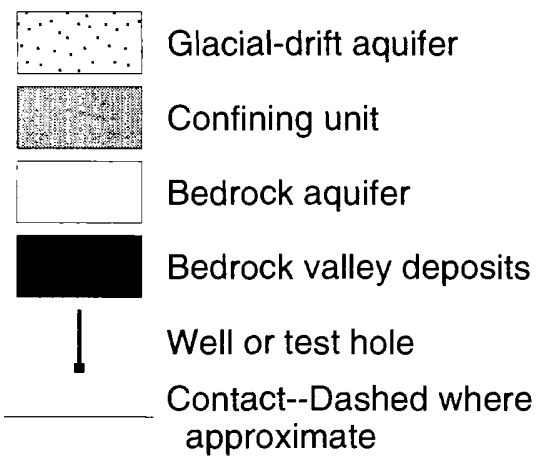

Figure 5. Hydrogeologic section B-B' showing hydrogeologic units, St. Louis Park are?, Minnesota (trace of sections shown in figure 3 ). 


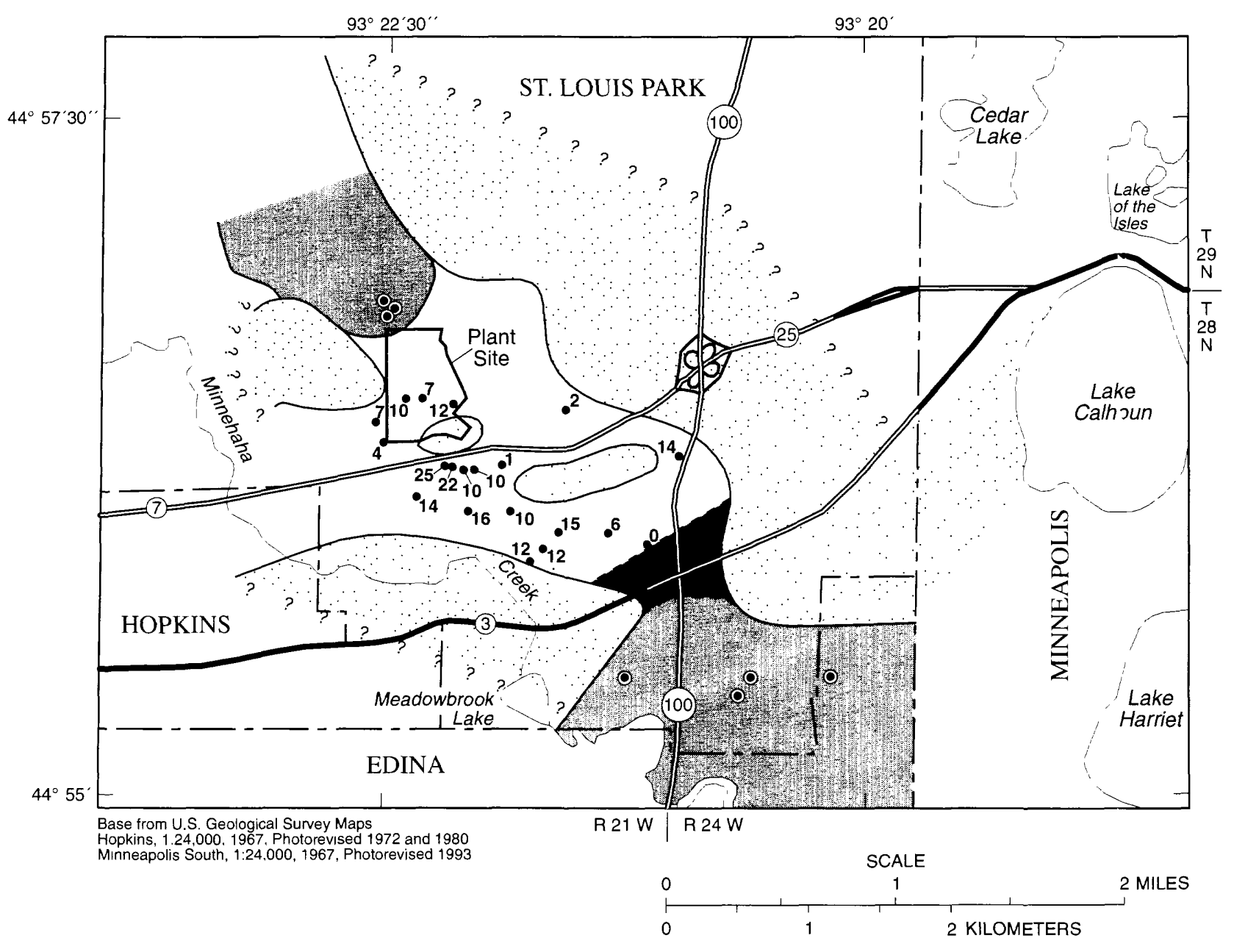

\section{EXPLANATION}

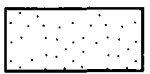

Upper drift confining unit absent. Upper and middle drift aquifers comprise a continuous unconfined aquifer--A "?" indicates sufficient data is not available beyond patterned area to determine extent of upper drift confining unit.

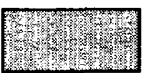

Upper drift aquifer absent. Upper drift confining unit at land surface.

Unsaturated sand and gravel at land surface. Water table is at or below top of upper drift confining unit.

Upper drift aquifer underlain by upper drift confining unit.

.7 Test hole--Number is saturated thickness of aquifer, in feet.

- Test hole--Aquifer absent, with till or clay present at land surface.

Figure 6. Saturated thickness of upper drift aquifer, St. Louis Park area, Minnesota. 


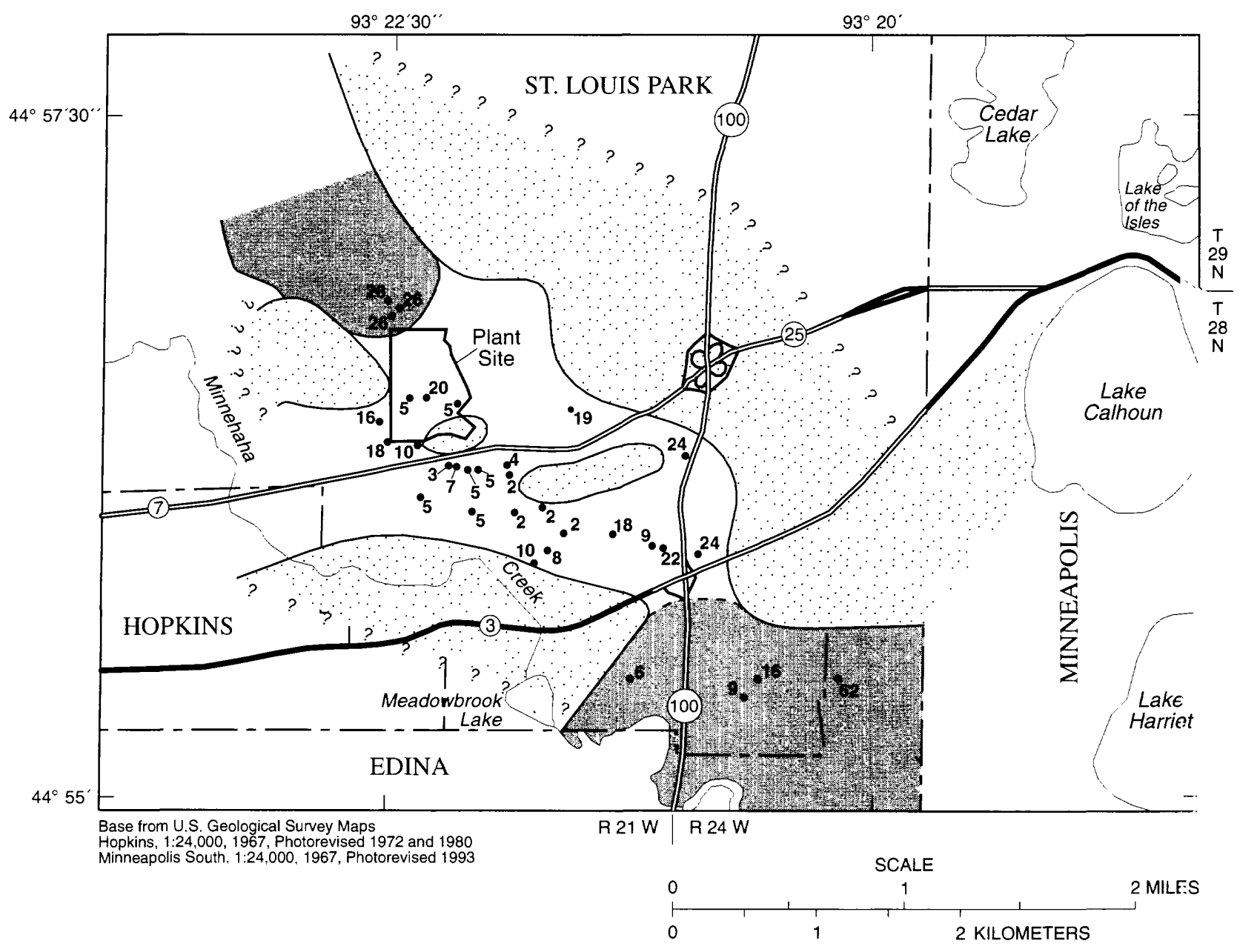

\section{EXPLANATION}

Upper drift confining unit absent. Upper and middle drift aquifers comprise a continuous unconfined aquifer--A "?" indicates sufficient data is not available beyond patterned area to determine extent of upper drift confining unit.

mener drift aquifer absent. Upper drift confining unit at

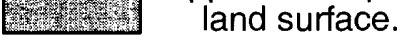

.7 Test hole--Number is thickness of upper drift confining unit, in feet.

Figure 7. Thickness of upper drift confining unit, St. Louis Park area, Minnesota. 


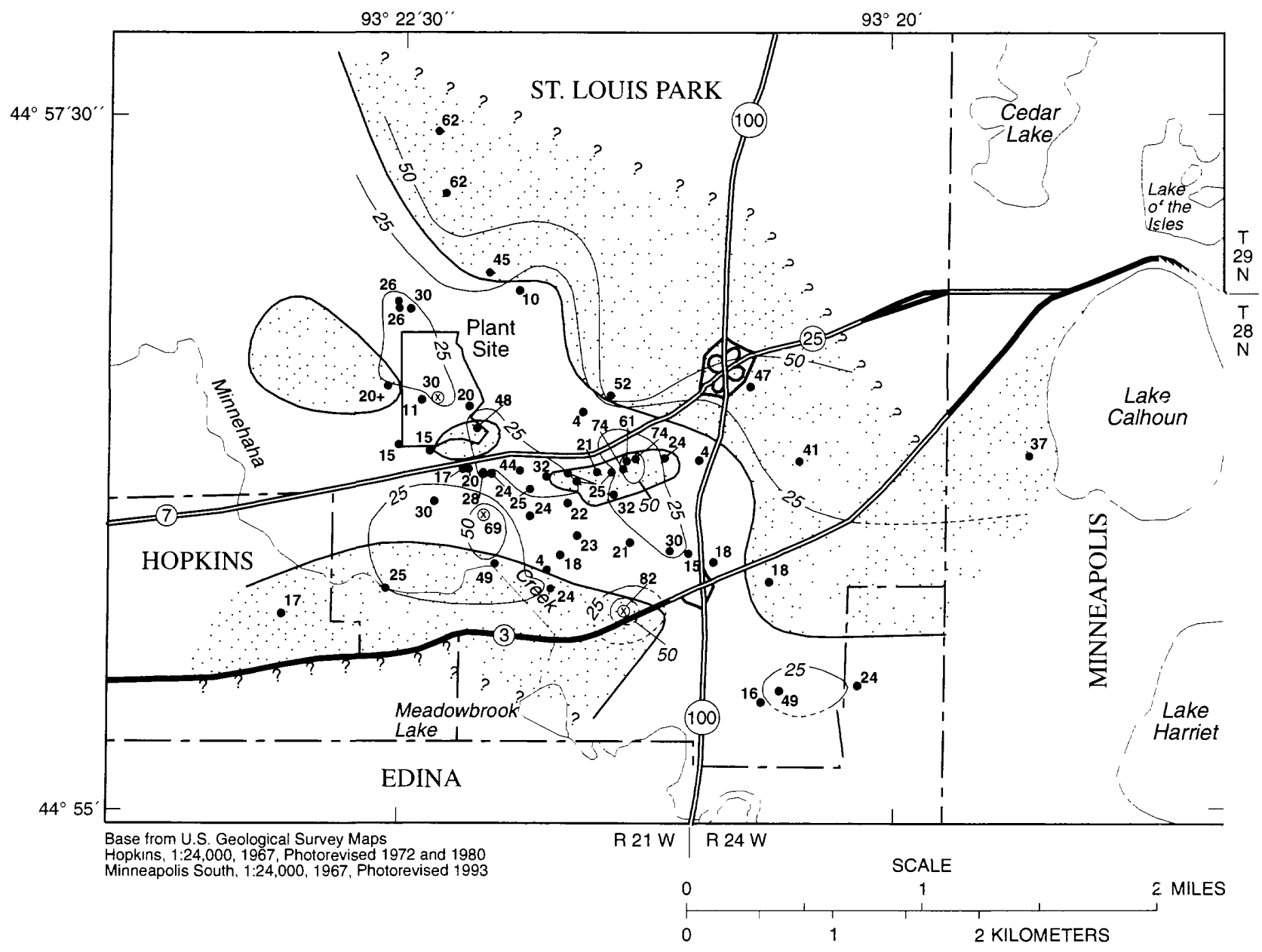

\section{EXPLANATION}

Upper drift confining unit absent. Upper and middle drift aquifers comprise a continuous unconfined aquifer--A "?" indicates sufficient data is not available beyond patterned area to determine extent of upper drift confining unit.

- 50 - Line of equal saturated thickness of middle drift aquifer--Dashed where approximate. Contour interval 25 feet.

.$^{20+} \quad$ Test hole--Number is saturated thickness of middle drift aquifer in feet. A plus (+) indicates that the hole did not penetrate to the bottom of the aquifer.

$\otimes^{30} \quad$ Test hole--No confining unit present between the middle drift and lower drift aquifers; sand and gravel unit extends downward to the bedrock surface.

Figure 8. Saturated thickness of middle drift aquifer, St. Louis Park area, Minnesote . 
unit; and (2) a lower unit that consists of the lower part of the lower drift confining unit and discontinuous sand and gravel deposits, hereinafter referred to as the lower drift aquifer, overlying the Platteville Formation. The discontinuous sand and gravel deposits comprising the lower drift aquifer are laterally separated by the sandy to silty clays and tills of the lower drift confining unit. The lower drift confining unit is as much as $50 \mathrm{ft}$ thick where the underlying lower drift aquifer is present (fig. 9). The lower drift confining unit generally is about 5 to $20 \mathrm{ft}$ thick in the central part of the study area near the plant site. At some locations (underlying the plant site on section A-A', fig. 4) sand and gravel extends from the base of the upper drift confining unit to the bedrock surface. At places where both the upper and lower drift confining units are absent, sand and gravel extends from the land surface to the bedrock surface. Continuous sequences of sand and gravel extending from land surface, or from the base of the upper drift confining unit to the bedrock, underlie relatively small, isolated areas.

The thickness of the lower drift aquifer is as much as $20 \mathrm{ft}$ where it is overlain by the lower drift confining unit (fig. 10). The lower drift aquifer generally is present in a northwest-to-southeast trending band (about 0.3 to 1.0 mile wide) transecting the plant site and generally absent outside this band (fig. 10). The lower drift aquifer generally is under confined conditions, except at those sites where both the upper and lower drift confining units are absent. The combination of the middle and lower drift aquifers is as much as $69 \mathrm{ft}$ thick at sites where the lower drift confining unit is absent and the middle and lower drift aquifers are continuous (fig. 10). The lower drift aquifer is composed of medium-tocoarse grained sand and fine gravel. Locally, the gravel includes weathered limestone rubble and coarse gravel. The horizontal hydraulic conductivity of the lower drift aquifer ranges from about 100 to $500 \mathrm{ft} / \mathrm{d}$, based on the grain-size distribution.

Previous studies conducted in the Minneapolis-St. Paul Metropolitan Area have combined the Decorah Shale, Platteville Formation, and Glenwood Shale into a single regional confining unit (Guswa and others, 1982; Stark and Hult, 1985; Schoenberg, 1990; Lindgren, 1990). The Decorah Shale is not recorded in water-well logs in the study area and is not included as a hydrogeologic unit for the purposes of this study. The Platteville Formation locally yields small to moderate supplies of water to wells: therefore, it is classified as an aquifer for the purposes of this study. The Platteville aquifer underlies the drift over most of the study area. The Platteville aquifer and underlying Glenwood confining unit are dissected by bedrock valleys in the central and southeastern parts of the study area (fig. 3), where the drift is underlain by the St. Peter aquifer (Olsen and Bloomgren, 1989). Olson and others (1974) suggested the bedrock valleys in the St. Louis Park area were formed during glacial periods by streams that formed in front of the glacial margin (proglacial streams). Valleys possibly eroded by preglacial or proglacial streams also may have been substantially modified by plucking and abrasion beneath the glaciers (Hult and Schoenberg, 1984).

The Platteville aquifer is a gray to buff, thin-tomedium bedded dolomitic limestone and dolomite with some shale partings, and is as much as $29 \mathrm{ft}$ thick in the study area (fig. 11). The aquifer is under confined conditions, except in areas where both the upper drift and lower drift confining units are absent (section A-A', fig. 4). Ground-water flow in the Platteville aquifeprimarily is through fractures, open joints, and solution channels. Fractures and solution channels are concentrated in the upper part of the aquifer. Specific capacities of wells completed in the aquifer generally are between 10 and $100 \mathrm{gal} / \mathrm{min}$ per foot of drawdc' $\mathrm{wn}$ (Stark and Hult, 1985). Results from one aquifer test indicate the transmissivity of the aquifer is about 9,000 $\mathrm{ft}^{2} / \mathrm{d}$ (Stark and Hult, 1985). Rocks with secondary solution cavity and fracture permeability, such as $\mathrm{tl}$ ? Platteville aquifer, often have heterogeneous hydra.lic properties that differ widely within the aquifer. Liesch (1973) has documented large local differences in the transmissivity and storage coefficient of the Platteville aquifer near Minnehaha Creek in Minneapolis. Hul' and Schoenberg (1984), however, state that short-term pumping tests indicate the hydraulic characteristics of the Platteville aquifer, particularly transmissivity, are reasonably uniform in the St. Louis Park area.

The Platteville aquifer is underlain by the Glenw'sod confining unit, a green to buff, plastic to slightly fissile shale and claystone. The Glenwood confining unit was dissected by erosion and is discontinuous in the stuty area. The confining unit has a maximum thickness of about $15 \mathrm{ft}$. Because commonly it is not recorded in water-well logs, detailed information about the unit's thickness and the location of possible discontinuities is lacking, particularly near the bedrock valleys. The confining unit, where present, impedes the flow of ground water between the Platteville aquifer and the underlying St. Peter aquifer. The vertical hydraulic conductivity of the confining unit is estimated to be about $10^{-10} \mathrm{ft} / \mathrm{s}\left(9 \times 10^{-6} \mathrm{ft} / \mathrm{d}\right)$, based on laboratory measurements of core samples (Hult and Schoenberg, 1984). 


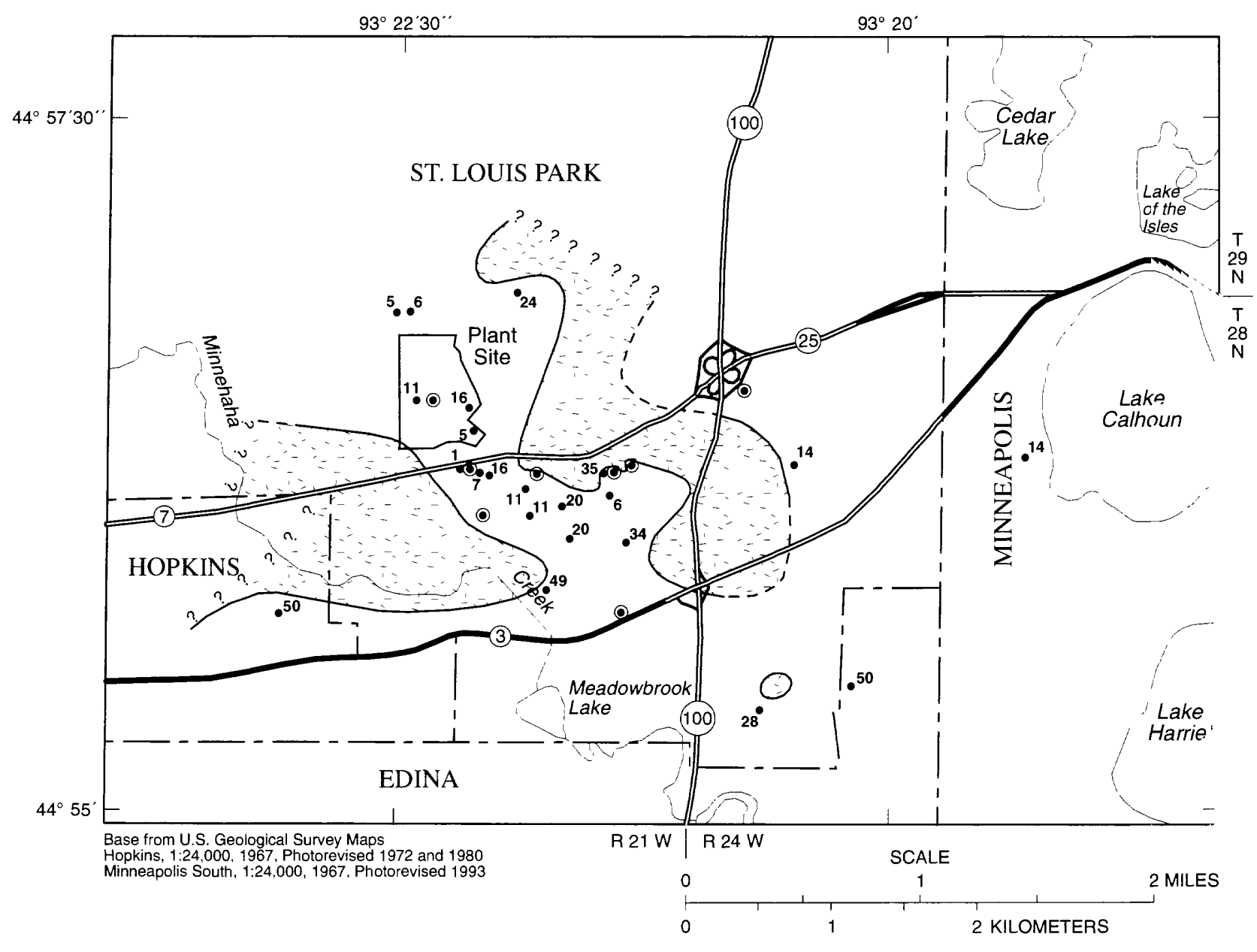

\section{EXPLANATION}

Lower drift aquifer absent--Dashed where approximate.

A "?" indicates sufficient data is not available beyond

patterned area to determine if lower drift aquifer is absent.

. ${ }^{16}$ Test hole--Number is thickness of lower drift confining unit, in feet.

- Test hole--Confining unit absent.

Figure 9. Thickness of lower drift confining unit, St Louis Park area, Minnesota. 


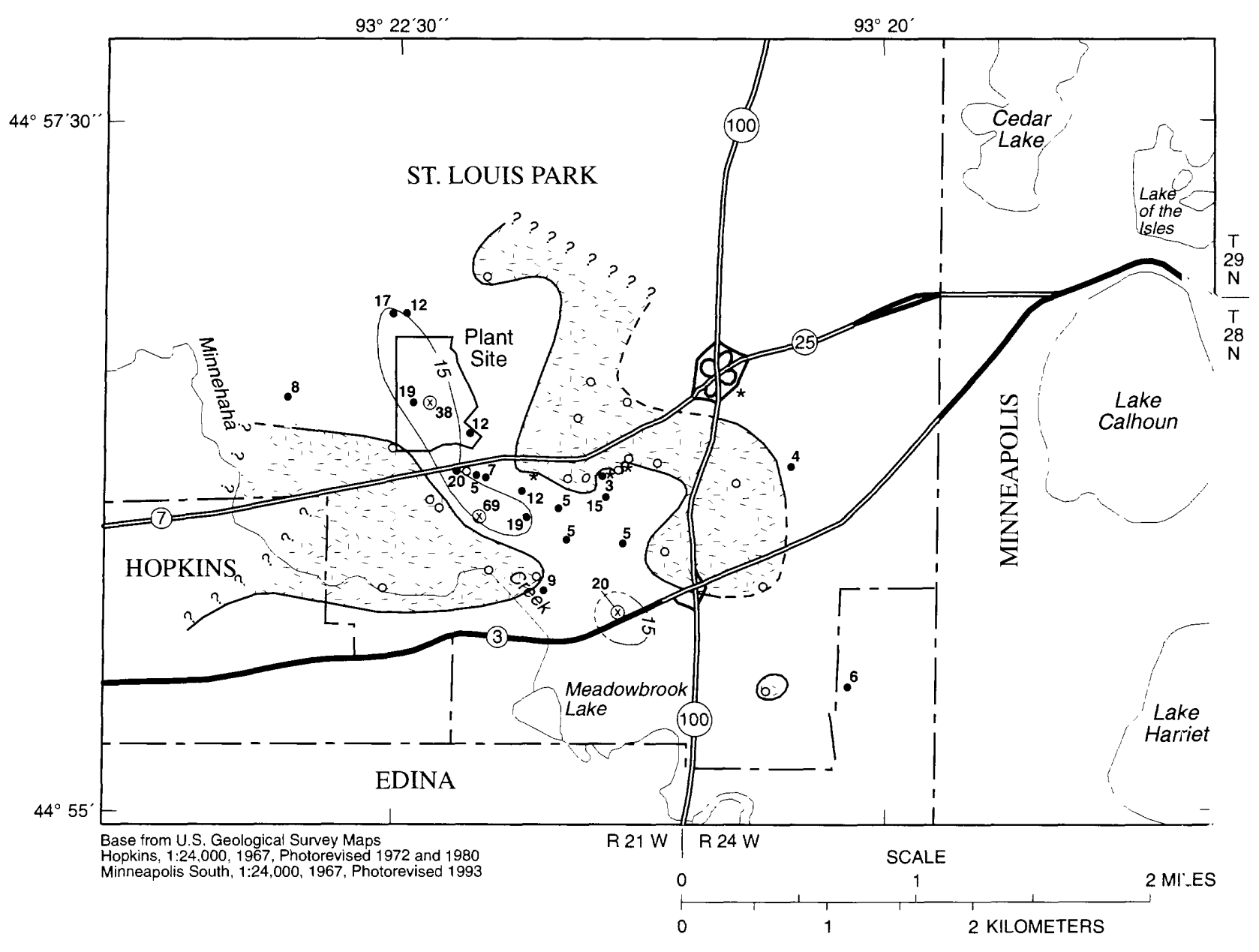

\section{EXPLANATION}

Lower drift aquifer absent--Dashed where approximate.

A "?" indicates sufficient data is not available beyond patterned area to determine if lower drift aquifer is absent.

-15-_ Line of equal thickness of lower drift aquifer--Dashed where approximate. Interval is variable.

.$^{15}$ Test hole--Number is thickness of lower drift aquifer, in feet.

$\otimes^{38} \quad$ Test hole--No confining unit present between the middle drift and lower drift aquifers; sand and gravel unit extends downward to the bedrock surface.

* Test hole--Sand and gravel extends from the land surface downward to the bedrock surface, with no intervening confining units.

- Test hole--Lower drift aquifer absent.

Figure 10. Thickness of lower drift aquifer, St. Louis Park area, Minnesota. 


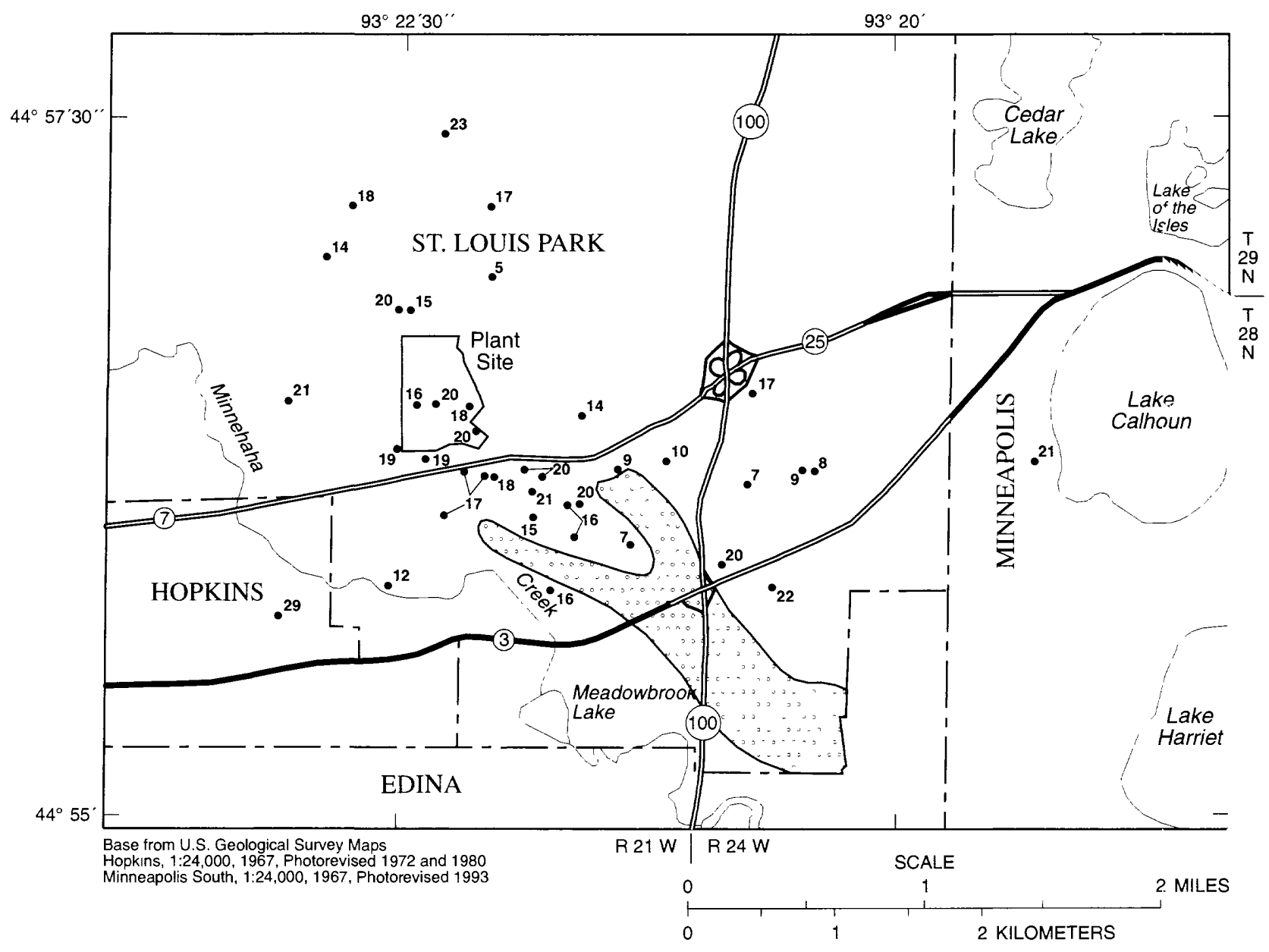

EXPLANATION

…… absent and drift is underlain by St. Peter aquifer.

.$\quad$ Test hole--Number is thickness of Platteville aquifer, in feet.

Figure 11. Thickness of Platteville aquifer, St. Louis Park area, Minnesota. 
The St. Peter aquifer is a white to yellow, fine-to medium-grained, well-sorted, friable sandstone. Near the plant site the St. Peter aquifer is about $125 \mathrm{ft}$ thick. The aquifer is under confined conditions. Norvitch and others (1974) report hydraulic conductivities for the St. Peter aquifer ranging from about 1 to $25 \mathrm{ft} / \mathrm{d}$. Stark and Hult (1985) report a hydraulic conductivity of $20 \mathrm{ft} / \mathrm{d}$ for the St. Peter aquifer in the St. Louis Park area.

The base of the St. Peter Sandstone generally consists of 5 to $65 \mathrm{ft}$ of siltstone and shale. This lowpermeability bed is referred to as the basal St. Peter confining unit. It acts as a confining unit within the ground-water-flow system. The basal St. Peter confining unit impedes the flow of ground water between the St. Peter aquifer and the underlying Prairie du Chien-Jordan aquifer. Stark and Hult (1985) report a vertical hydraulic conductivity of $0.0009 \mathrm{ft} / \mathrm{d}$ for the basal St. Peter confining unit in the St. Louis Park area. Norvitch and others (1974) report vertical hydraulic conductivities as low as $10^{-6} \mathrm{ft} / \mathrm{d}$ for the basal St. Peter confining unit in the Minneapolis-St. Paul Metropolitan Area.

\section{Ground-Water Flow}

\section{Characterization of Recharge, Discharge, and Flow Between Hydrogeologic Units}

Water in the drift aquifers and in the Platteville aquifer generally flows from west to east across the study area under a hydraulic gradient of about $10 \mathrm{ft} / \mathrm{mi}$ (figs. 12 and 13). Southeast of the plant site, water in the drift and Platteville aquifer system generally flows from the northwest to the southeast. Water in the underlying St. Peter and Prairie du Chien-Jordan aquifers also generally flows from west to east across the study area, with a northwest to southeast component of flow southeast of the plant site (Lorenz and Stark, 1990; Stark and Hult, 1985). The potentiometric surface of the upper and the middle drift aquifers (fig. 12) represents a composite of the hydraulic heads in both aquifers. Hydraulic heads in the two aquifers are similar at any location in the study area (generally within about $0.1 \mathrm{ft}$ ). Combining the available data gives a more complete representation of the potentiometric surface because available data in each aquifer unit are limited. The directions of ground-water flow and hydraulic gradients of the upper drift aquifer, the middle drift aquifer, and the Platteville aquifer are similar (Hult and Schoenberg. 1984). Available water-level measurements indicate that hydraulic heads in the lower drift aquifer are similar (within $0.1 \mathrm{ft}$ ) to those in the Platteville aquifer at the same location.
Sources of water (recharge) to the drift and Plat"eville aquifer system in the study area are infiltration fre $m$ precipitation and ground-water inflow to the drift and Platteville aquifers from the west. Norvitch and cthers $(1974$, p. 66) estimated that the mean recharge to the water table, calculated as precipitation minus evapotranspiration, is $6.4 \mathrm{in} . / \mathrm{yr}$ in the Minneapolis-St. Paul Metropolitan Area. Helgeson and Lindholm (1977, p. 16) estimated recharge to the unconfined drift aquifer underlying the Anoka Sand Plain in the northern part of the Minneapolis-St. Paul Metropolitan Area to be $11.1 \mathrm{in} . / \mathrm{yr}$, based on hydrograph analysis. The amount of ground-water inflow to the drift and Platteville aquifer system in the study area is not known beca'se of a lack of data beyond the immediate area of the plant site.

Discharge from the drift and Platteville aquifer system in the study area consists of (1) ground-water outflow from the drift and Platteville aquifers to ths east, (2) ground-water discharge to surface-water bodies, (3) ground-water evapotranspiration, (4) ground-water withdrawals by wells, and (5) downward leakage to the underlying St. Peter aquifer. The amount of groundwater outflow from the drift and Platteville aquifer system through the eastern study-area boundary is not known because of a lack of data beyond the immediate area of the plant site.

Ground water from the upper drift aquifer discharges to Minnehaha Creek, and ground water from both the upper drift and deeper aquifers discharges to the lakes near the eastern boundary of the study area. Low-flow discharge measurements in November 1978, at fo. Ir locations on Minnehaha Creek, indicated discharges of $10.9,11.7,14.1$, and $12.8 \mathrm{ft}^{3} / \mathrm{s}$ (Hult and Schoenberg, 1984 , p. 31). The observed differences in streamflow between measuring points represent net gains or losses of the stream from or to the ground-water system. A portion of each observed difference (as much as 5 percent of measured streamflows) may be due to measurement errors. The amount of ground-water discharge to the lakes is not known.

Discharge from the drift and Platteville aquifer system by ground-water evapotranspiration occurs by direct evaporation of water from the water table v'here the water table is at or near the land surface, and transpiration by plants where the water table is within the rooting depth of plants (usually less than about 10 $\mathrm{ft}$ ). The amount of ground-water evapotranspiration in the study area is not known, but may be significant in the bog areas where the water table is near the lard surface. 


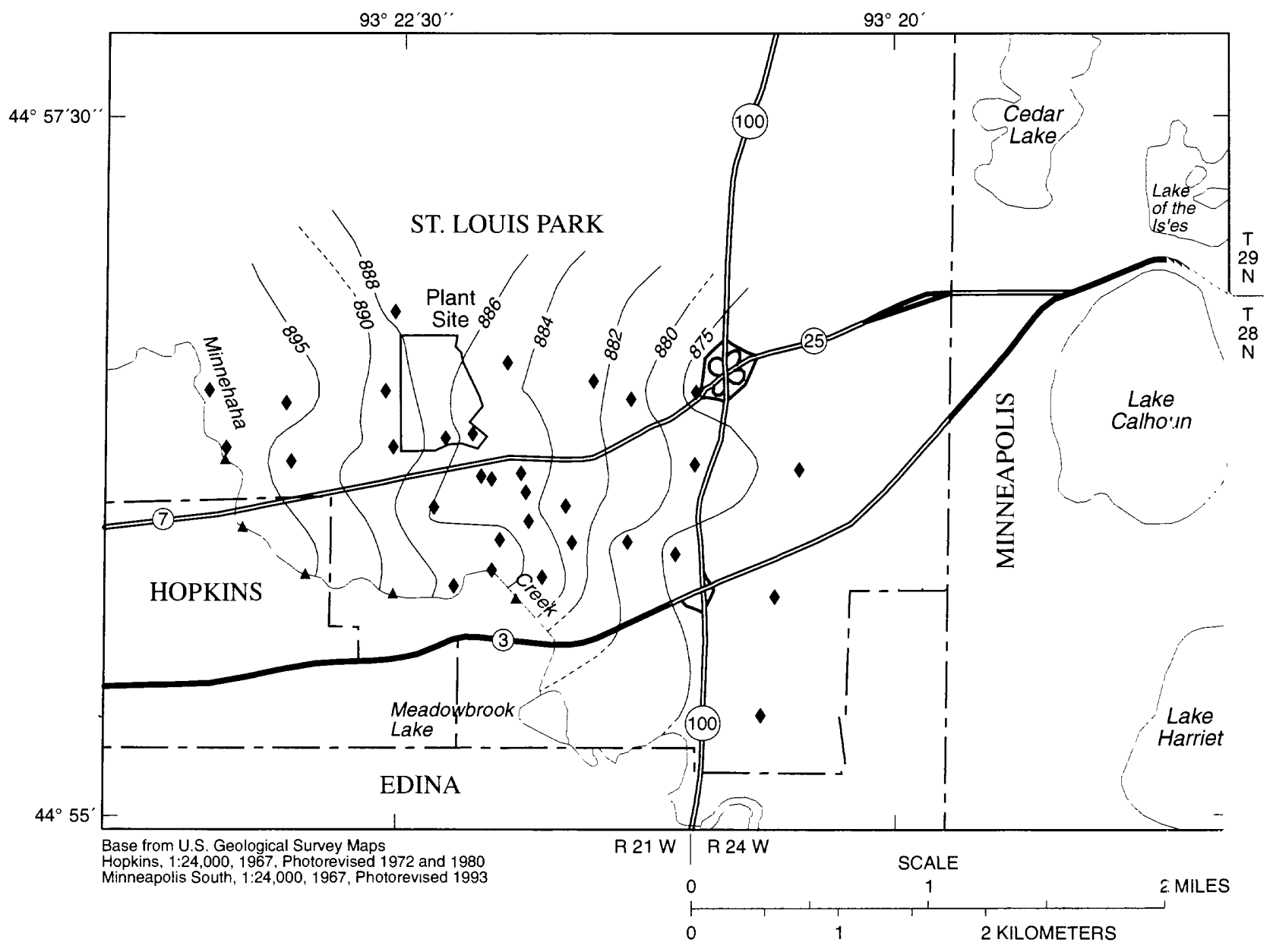

EXPLANATION

- 890 - Potentiometric contour--Shows altitude at which water levels would stand in tightly cased wells. Dashed where approximate. Contour interval is variable. Datum is sea level.

- Observation well

- Stream-stage measurement location

Figure 12. Composite potentiometric surface of the upper and middle drift aquifers, December 1987, St. Louis Park area, Minnesota. 


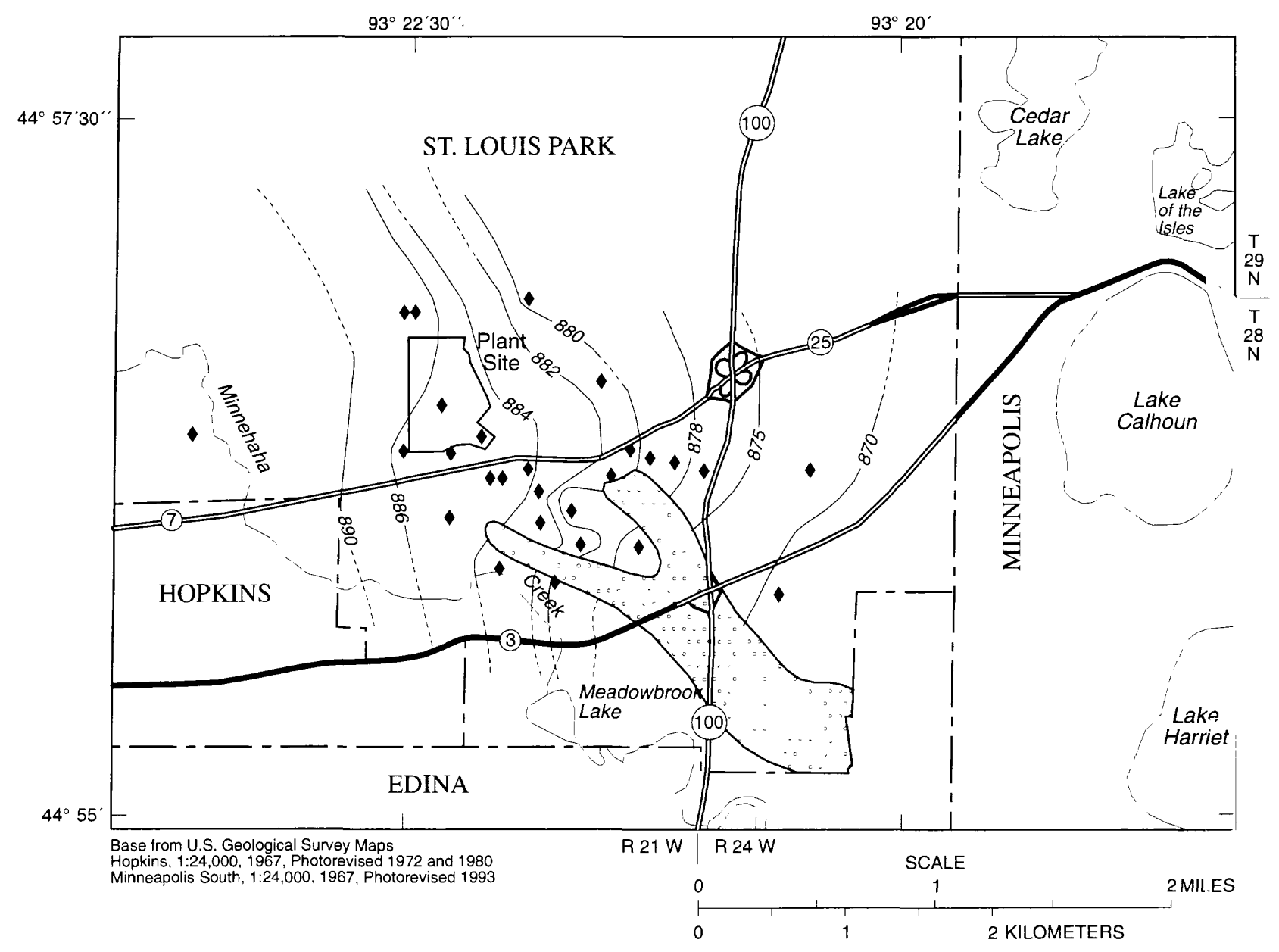

EXPLANATION

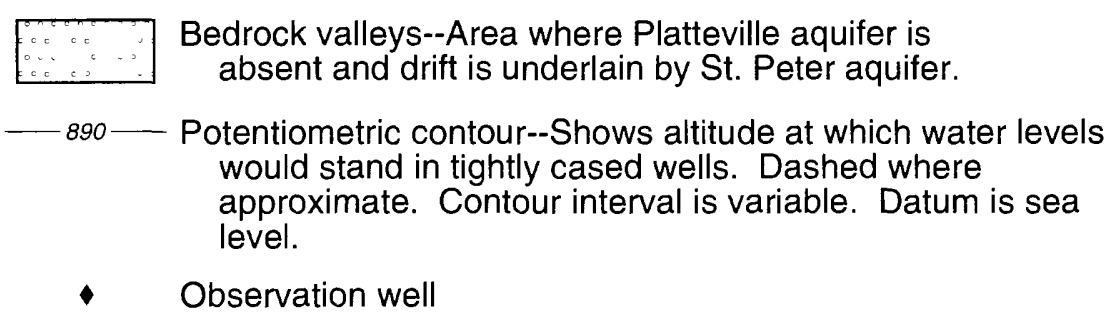

Figure 13. Potentimetric surface of the Platteville aquifer, December 1987, St. Louis Park area, Minnesota. 
Discharge of ground water by withdrawals from wells in the study area is considered negligible. Prior to 1988, no large-capacity wells withdrew water from the drift and Platteville aquifer system. Beginning in 1988 , remedial measures were begun to capture and control the spread of contaminated ground water in the drift and Platteville aquifer system, with gradient-control wells withdrawing ground water from the drift and Platteville aquifers. Otherwise, no high-capacity wells are known to obtain water supplies from the drift and Platteville aquifer system in the study area. The amount of water lost from the drift and Platteville aquifer system by the downward leakage of water to the underlying St. Peter aquifer is not known.

Horizontal and vertical directions of flow in the drift and Platteville aquifer system may be illustrated using hydrogeologic sections and equipotential lines (fig.

14). The directions of ground-water flow in the drift and Platteville aquifer system are perpendicular to the equipotential lines, as shown in figure 14. Groundwater flow is predominantly horizontal in aquifers, as indicated by small variations in hydraulic head vertically within aquifer units. Vertical differences in hydraulic head within the middle drift aquifer generally are less than $0.03 \mathrm{ft}$ and flow within the aquifer is primarily horizontal. Ground-water flow in confining units has a substantial vertical component. The difference in hydraulic heads between the top and bottom of the basal drift complex, composed of the lower drift confining unit and the lower drift aquifer, ranges from about $0.15 \mathrm{ft}$ to about $0.60 \mathrm{ft}$, with heads decreasing with increasing depth. The relatively large vertical gradients indicate the vertical leakage of water out of the middle drift aquifer downward through the basal drift complex. Hydraulic head differences within the Platteville aquifer are not well known because of limited data. but Hult and Schoenberg (1984) indicate that significant vertical gradients may exist within the aquifer.

The confining units control the vertical movement of water through the drift and Platteville aquifer system. Water leaks downward (1) from the upper drift aquifer to the middle drift aquifer through the upper drift confining unit, (2) from the middle drift aquifer to the lower drift aquifer or the Platteville aquifer through the lower drift confining unit, and (3) from the Platteville aquifer to the St. Peter aquifer through the Glenwood confining unit. The amount of leakage depends on the vertical hydraulic conductivity and thickness of the confining unit, and the difference in hydraulic heads between the aquifers. Discontinuities in the confining units affect vertical flow in the drift and Platteville aquifer system. The absence of low-permeability material separating aquifer units allows for relatively unimpeded downward leakage of water. Therefore, discontinuities in confining units may serve as preferential pathways for ground-water flow.

Winter and Pfannkuch (1976) discussed the hydrogeologic significance of drift-filled bedro $k$ valleys in the Minneapolis-St. Paul Metropoliten Area. They suggested that many of these bedrock valleys may be filled with coarse-grained deposits and coulc provide preferential pathways for ground-water flow and for the movement of contaminants. The Plateville aquifer and Glenwood confining unit have been removed b:" erosion, leaving bedrock valleys in the central and southeastern parts of the study area; the valleys are filled with drift. Variations in vertical leakage of water between hydrogeologic units depend on both hydraulic conductivities and hydraulic gradients. The vetical hydraulic head difference between the middle drift aquifer and the Platteville aquifer ranges from less than $0.1 \mathrm{ft}$ at observation wells farthest from the bedrock valleys to as much as about $10 \mathrm{ft}$ near the bedrock valleys. These vertical hydraulic head differen res indicate that the vertical leakage of water out of the middle drift aquifer through the lower drift confining unit may be greater in the vicinity of the bedroc valleys than away from them, depending on variations in hydraulic conductivities. Also, the hydraulic hoad difference between the Platteville and St. Peter aquifers ranges from about $20 \mathrm{ft}$ in areas where the Plat ${ }^{\circ}$ ville aquifer is underlain by the Glenwood confining unit to nearly zero near the bedrock valleys. The similarity in hydraulic heads and lack of a significant vertical gradient (between the Platteville and St. Peter aquifers) may indicate lateral movement of water out of the Platteville aquifer and into the drift filling the $r$ odrock valleys.

\section{Cross-Sectional Model}

A numerical cross-sectional ground-water-flow model was constructed and calibrated for steady-state conditions. The cross-sectional model was used to test concepts of flow of ground water through the drift and Platteville aquifer system, particularly the efferts of confining units and bedrock valleys on vertical flow. The numerical model used for this study was the U.S. Geological Survey modular three-dimensional finitedifference ground-water-flow model developed by McDonald and Harbaugh (1988). The model uses finite-difference methods to obtain approximate solutions to partial-differential equations of groundwater flow. The model incorporates horizontal and vertical flow equations, aquifer hydraulic properties, and 


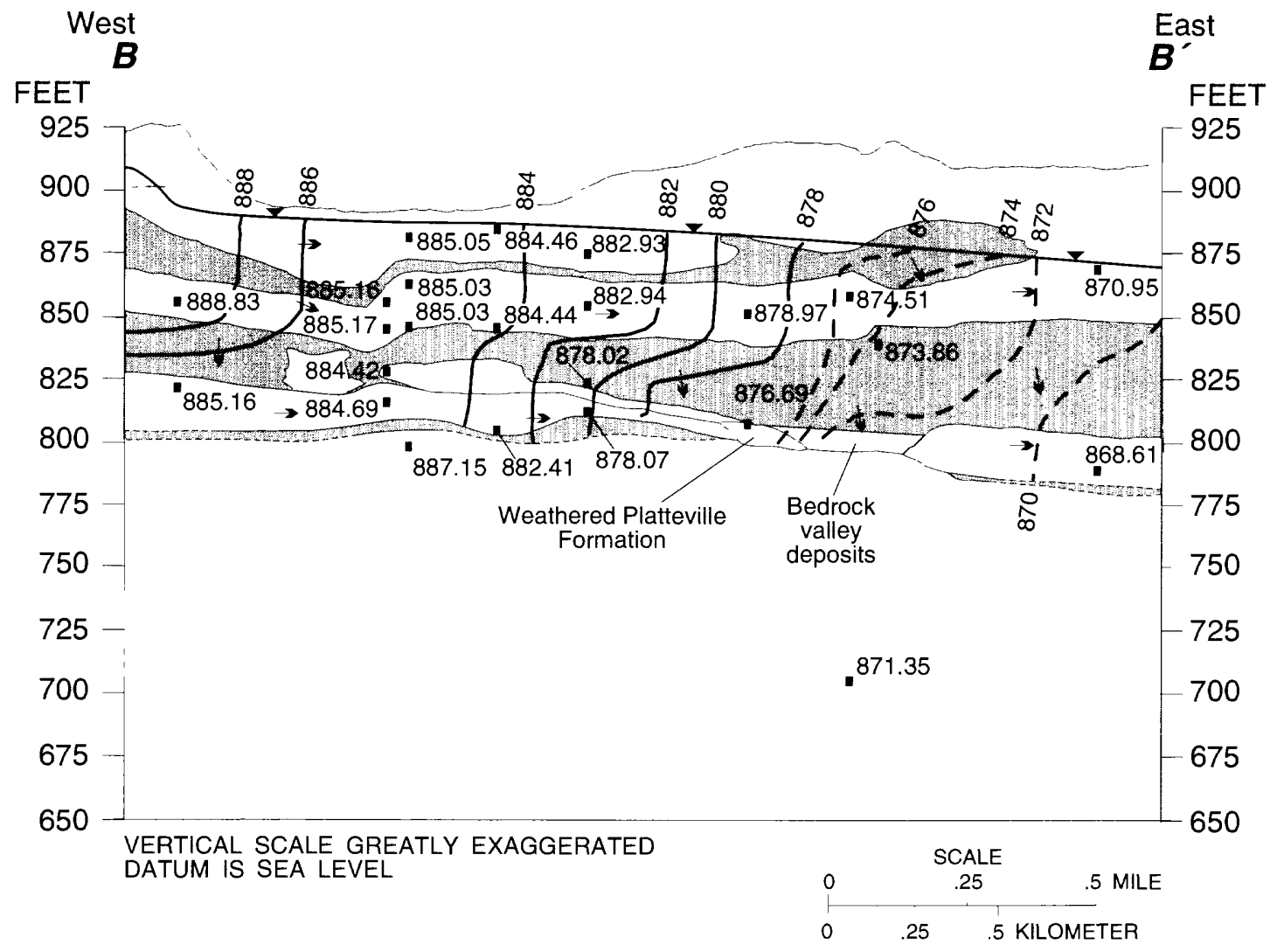

\section{EXPLANATION}

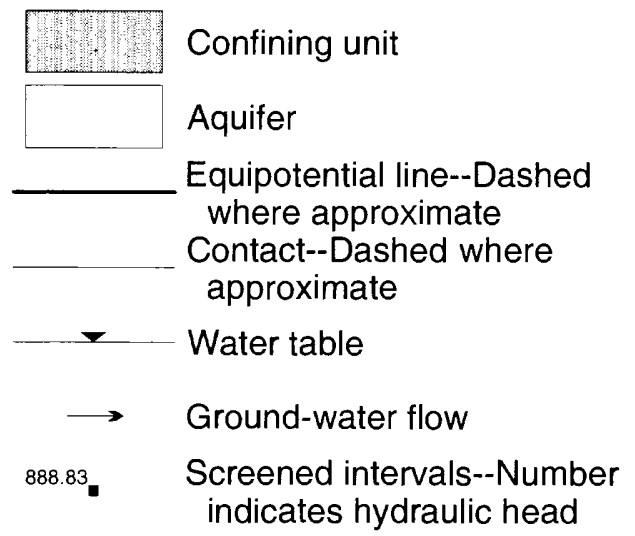

Figure 14. Hydrogeologic section showing hydraulic heads in December 1987, equipotential lines, and direction of ground-water flow, St. Louis Park area, Minnesota (trace of section shown in figure 3). 
recharge to and discharge from the aquifers to calculate hydraulic heads in the aquifers.

The use of particle-tracking techniques to generate path lines and time-of-travel information from the results of numerical models can be helpful in analyzing ground-water-flow systems. A particle-tracking postprocessing package developed by Pollock (1989) was used to compute ground-water-flow path lines based on output from steady-state simulations obtained with the U.S. Geological Survey modular model. The particletracking package graphically presents the results of the path-line calculations. Path lines are calculated using a semi-analytical particle-tracking scheme. Given the initial position of a particle anywhere in a model cell, the coordinates of any other point along the path line within the cell, and the time of travel between them, can be computed directly.

A conceptual model was formulated on the basis of the hydrogeologic setting, aquifer characteristics, aquifer recharge and discharge, and aquifer and confining unit boundary conditions. The conceptual model is a qualitative description of the known hydraulic characteristics and functioning of the hydrogeologic system. Simplifying assumptions are necessary to mathematically represent the hydrogeologic system. The major concepts of flow, the associated assumptions, and the boundary conditions necessary for the model are:

1. The upper drift aquifer, the upper drift confining unit, and the middle drift aquifer are recharged by infiltration of precipitation where they are not overlain by other hydrogeologic units.

2. The upper drift aquifer is unconfined. The middle drift aquifer is unconfined or confined, depending on the absence or presence of an overlying confining unit. The lower drift, Platteville, St. Peter, and Prairie du Chien-Jordan aquifers are confined.

3. Some natural hydrologic boundaries lie beyond the modeled cross-section transect, and ground water flows laterally across arbitrarily imposed model boundaries.

4. The trace of the cross-section is aligned with the major horizontal flow paths in the aquifers and no significant horizontal flow, not aligned with the trace, occurs in the drift and Platteville aquifer system.

5. The volume of water that moves vertically through the base of the Prairie du Chien-Jordan aquifer is small relative to the lateral flow and the base can be treated as a no-flow boundary.
6. Ground-water withdrawals from the drift and Platteville aquifer system are negligible and withdrawals from the underlying aquifers have a negligible effect on hydraulic heads in the drift and Platteville aquifer system.

\section{Model design}

The $\mathrm{C}-\mathrm{C}^{\prime}$ cross-section (fig. 3) was chosen to represent the drift and Platteville aquifer system and to investigate concepts of flow of ground water using the numerical model. The trace of the section is aligned with the major horizontal flow path. There are no significant horizontal flows normal to the simulcted flow path. Hydraulic heads and ground-water flow along the cross section were simulated by the numerical model using 1 row and 91 columns (fig. 15). The numerical model along the cross section requires only one row because a vertical slice through the system, ratrer than the entire three-dimensional system, is simulated. The dimensions of each grid cell are $100 \mathrm{ft}$ by $100 \mathrm{ft}^{t}$. The model was subdivided vertically into 8 layers, each corresponding to a horizontal hydrogeologic unit.

The thickness of a cell representing an aquifer unit is incorporated in the transmissivity term for the cell. Transmissivity is the product of the hydraulic conductivity and the saturated thickness. Hydraulic conductivity and transmissivity are measures of the ability of an aquifer to transmit water. Transmissivity of an unconfined aquifer can vary with changes in the saturated thickness of the aquifer, whereas the transmissivity of a confined aquifer is constant with time because the saturated thickness of the aquifer does not change.

The center of a grid cell, referred to as a nod?, represents the location for which the hydraulic head is computed by the cross-sectional model. Aquifer properties and stresses are assigned to the cells and are assumed to represent mean conditions within grid cells. Specific nodes and cells are referenced by citing row (i), column ( $j)$, and layer $(k)$. The row number (i) is always one for the cross-sectional model because there is only one row in the model grid.

The cross-sectional model contains eight layers that represent, in descending order (1) the upper drift aquifer, (2) the upper drift confining unit, (3) the middle drift aquifer, (4) the upper part of the lower drift confining unit, (5) the lower drift aquifer and la terally adjacent lower part of the lower drift confining unit, (6) the Platteville aquifer and bedrock valley deposits, (7) the St. Peter aquifer, and (8) the Prairie du Chien-Jordan aquifer (fig. 15). The model layer representing the Prairie du Chien-Jordan aquifer was included to extend 
C

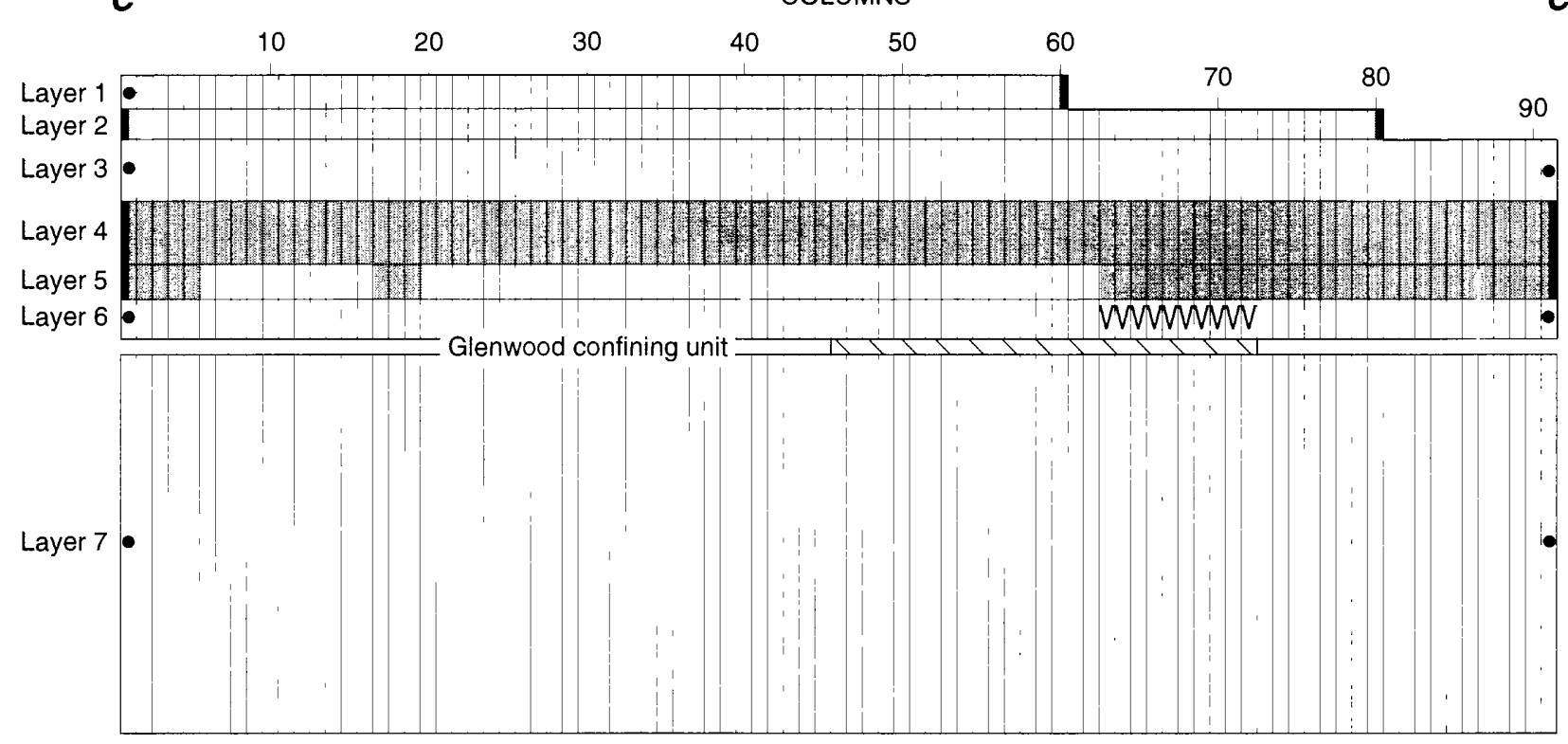

Basal St. Peter confining unit

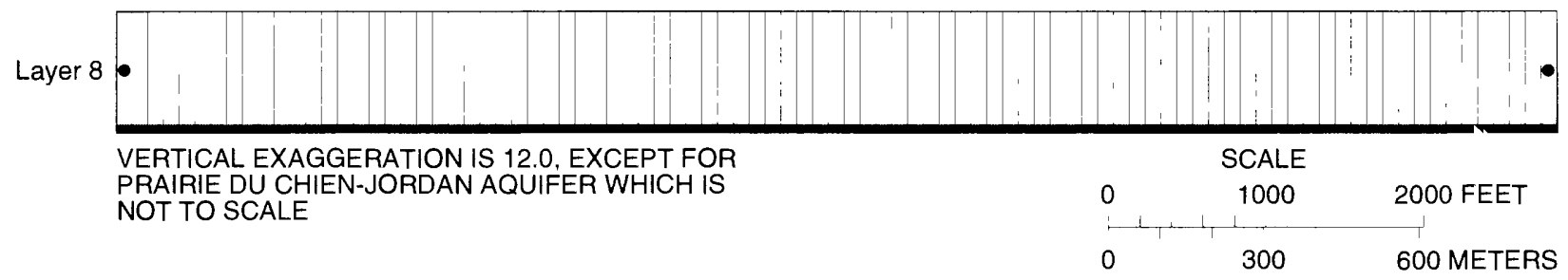

EXPLANATION

Layers represent hydrogeologic units:

Layer 1 -- Upper drift aquifer

Layer 2 -- Upper drift confining unit

Layer 3 -- Middle drift aquifer

Layer 4 -- Upper part of the lower drift confining unit

Layer 5 -- Lower drift aquifer and lower part of the lower drift confining unit

Layer 6 -- Platteville aquifer and bedrock valley deposits

Layer 7 -- St. Peter aquifer

Layer 8 -- Prairie du Chien-Jordan aquifer

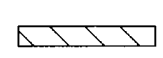

Cell representing lower drift confining unit

V Cell representing Bedrock valley deposits

- Specified-head boundary cell

$-$

No-flow boundary

Figure 15. Hydrogeologic units and cross-sectional model layers, St. Louis Park area, Minnesota (trace of section shown on figure 3). 
the model down vertically to an impermeable (no-flow) boundary. Model layer 5 represents both the lower drift aquifer and the laterally adjacent till and sandy till (low permeability material) of the lower part of the lower drift confining unit, where these materials directly overlie the Platteville aquifer and sand and gravel deposits are absent. Model layer 6 represents both the Platteville aquifer and sandy till in the bedrock valley (bedrock valley deposits, columns 63 to 72) where the Platteville aquifer is absent. The Glenwood and basal St. Peter confining units are represented in the model by leakage terms that incorporate the thickness and vertical hydraulic conductivity of the unit in each model cell.

The transmissivities of cells representing the upper drift aquifer vary as the model-calculated saturated thickness of the unit varies. The transmissivities of cells representing the lower drift confining unit, the lower drift aquifer, the Platteville aquifer, the St. Peter aquifer, and the Prairie du Chien-Jordan aquifer are constant in time for any individual model cell. The units are under confined conditions so their model-calculated saturated thicknesses do not vary. The upper drift confining unit and middle drift aquifer are confined along most of the cross section, but are unconfined near the eastern boundary where the overlying hydrogeologic units are absent. The transmissivities of cells representing these units vary where the units are under unconfined conditions and are constant in time where the units are under confined conditions.

Model-calculated leakage of water between model layers is dependent on the thicknesses and vertical hydraulic conductivities of cells representing adjacent layers and the hydraulic head difference between adjacent layers. The Glenwood confining unit. underlying the Platteville aquifer, and the basal St. Peter confining unit, underlying the St. Peter aquifer, are not represented as layers in the cross-sectional model. Ground-water flow in these confining units is assumed to be predominantly vertical, with no significant horizontal component of flow. The assumption is made that these confining units make no measurable contribution to the horizontal conductance of the overlying and underlying layers. In each case, the confining unit is represented in the cross-sectional model by vertical leakance terms that restrict vertical flow between the overlying and underlying aquifers. This formulation for the treatment of confining units is frequently referred to as the quasi-three-dimensional approach (McDonald and Harbaugh, 1988). A more detailed discussion of leakage of water between model layers is given in the Supplemental Information Section at the end of this report. The volume of water that moves vertically through the base of the Prairie du
Chien-Jordan aquifer is considered small, relative to lateral flow in that aquifer, and its base is treated as a noflow boundary.

Recharge to the upper drift aquifer occurs by percolation of precipitation to the water table and is represented in the cross-sectional model by a spacifiedflux boundary. For columns 61-80 the sand and gravel deposits overlying the upper drift confining unit are not represented in the model (and are not shown in fig. 15) because they are unsaturated. The simulated recharge in these columns (61-80) is applied dire :tly to model layer 2 (the upper drift confining unit). Simulated recharge is applied to model layer 3 (the middle drift aquifer) in areas where model layer 1 (the upper drift aquifer) and layer 2 (the upper drift confining unit) are absert and model layer 3 (the middle drift aquifer) is under watertable conditions (columns 81-91). The simulated recharge represents the net difference between precipitation and evapotranspiration losses.

Evapotranspiration losses include those occurrirg above the water table in the unsaturated zone and groundwater evapotranspiration losses.

The lower (horizontal) boundary in the crosssectional model represents the base of the Prairio du Chien-Jordan aquifer. The base of the Prairie du ChienJordan aquifer is underlain by the St. LawrenceFranconia confining unit and is represented as a no-flow boundary. The hydrogeologic units lying stratigraphically below the St. Lawrence-Franconia confining unit are thought to be in poor hydraulic connection with overlying units (Stark and Hult. 1985). The St. Lawrence-Franconia unit is a regional confining bed with a vertical hydraulic conductivity as little as $0.00007 \mathrm{ft} / \mathrm{d}$ (Schoenberg, 1990). Some vertical leakage of water from the base of the Prairie du Chien-Jordan aquifer through the St. Lawrence-Franconia corfining unit undoubtedly does occur. In the model, losses due to downward leakage of water through the bottom of the Prairie du Chien-Jordan aquifer are not simulated. These potential losses, though not considered significant, could result in recharge to the drift and Platteville aquifer system being underestimated in the model. Model sensitivity analysis, however, indicated that variations in the hydraulic properties and boundary conditions of cells representing the Prairie du ChienJordan aquifer (model layer 8) had no significant effect on model-calculated hydraulic heads and groun-water flow in cells representing the drift and Platteville aquifer system.

The particle-tracking post-processing progra $\eta$ used to calculate path lines requires that hydraulic properties and hydrologic conditions be specified, in addition to 
those needed for the U.S. Geological Survey modular model (Pollock. 1989). The porosity, defined as the ratio of the volume of interstices (voids) to the total volume of a rock or soil, must be specified for each cell. Recharge may be assigned to the top face of all cells or treated as an internal source for all cells. An internal source (or sink) is treated as if it was uniformly distributed throughout the volume of a cell. Simulated recharge was assigned to the top face of all cells for the particle-tracking results discussed in this report. In the numerical cross-sectional model, when a particle of water enters the simulated ground-water-flow system, it moves through the system until it reaches a boundary where flow is out of the system, or until it enters a cell containing an internal sink, such as a stream. No internal sinks are present along the cross-sectional model.

The cross-sectional model results are limited in terms of describing the hydrogeology at the plant site. The model represents a two-dimensional section of the drift and Platteville aquifer system along the principal direction of flow in the aquifers. The model cannot represent converging or diverging flow that would be expected near a bedrock valley, or any flow normal to the alignment of the flow tube. However, the modeling approach used is a valid method of conceptualizing vertical flow through the drift and Platteville aquifer system. The cross-sectional model integrates many interrelated factors of hydrogeology and the relative effects of discontinuities in confining units on groundwater flow and, presumably, contaminant migration.

\section{Boundary conditions}

Ideally, all model boundaries should represent the physical limits of the aquifer system or other hydrogeologic boundaries, such as a river. Practical considerations, such as limitations affecting the size of the area modeled, however, often necessitate the use of arbitrarily imposed model boundaries that are within the natural hydrologic boundaries. The natural hydrologic boundaries of the upper drift (western boundary), middle drift, Platteville, St. Peter, and Prairie du ChienJordan aquifers lic beyond the modeled transect. A specified-head boundary, incorporating measured hydraulic heads in the aquifers, was used for these model layers (fig. 15). The measured hydraulic heads allow a reasonable representation of hydraulic conditions at the model boundaries, assuming the model-computed fluxes through the boundaries are reasonable. The use of specified-head boundaries is appropriate for this model because ground-water withdrawals have a negligible effect on the drift and
Platteville aquifer system and the cross-sectional model is intended to be used for steady-state conditions.

No-flow boundaries (fig. 15) were used to represent the eastern boundary of the upper drift aquifer (model layer 1 ) and for both the eastern and western bountaries of the upper drift confining unit (model layer 2), the upper part of the lower drift confining unit (mode layer 4 ), and the lower drift aquifer and lower part of the lower drift confining unit (model layer 5). The eastern boundary of the upper drift aquifer is where the aquifer becomes unsaturated (fig. 14) and, therefore, the flux across this boundary is zero. Because flow in the upper and lower drift confining units predominantly is vertically downward (fig. 14), flux across the model boundaries is negligible. The geologic material near the eastern and western boundaries of model layer 5 , representing the lower drift aquifer and lower part of the lower drift confining unit, is till and sandy till. Flow near both the eastern and western boundaries is predominantly vertical; therefore, flux across the model boundaries is negligible.

Alternative boundary conditions that could have been used for model layers having a specified-head boundary include a specified-flux or a general-head boundary condition (McDonald and Harbaugh, 1988). A generalhead boundary was not used because of uncertainty regarding the physical extent and continuity of the drift aquifer units beyond the boundaries of the cross sertion. Because the cross-sectional model was intended to be used for steady-state conditions hydraulic heads and flux at the boundaries are constant. A specified-haad boundary was used because hydraulic heads in the aquifer units are known with more accuracy than the flux across the boundary.

\section{Model calibration}

Model calibration is the process in which initial estimates of aquifer properties and boundary conditions are adjusted until calculated hydraulic heads and simulated ground-water flows adequately match measured water levels and flows. Because independent or field-determined estimates of ground-water flow along the cross section are not available, the crosssectional model was calibrated by matching simulated and measured hydraulic heads only. Model-comfruted flows, however, were compared with estimates of flow based on known ranges of hydraulic properties for the hydrogeologic units. Calibration and evaluation of the model was conducted for steady-state (equilibrium) conditions for a winter period, when ground-water withdrawals in the Minneapolis-St. Paul Metropolitan Area are smallest (on a seasonal basis). No storage 
terms or ground-water withdrawals are included in the steady-state simulation. Under steady-state conditions, the amount of water entering the aquifer system equals the amount of water leaving the aquifer system, and the long-term change in storage is zero.

Measured hydraulic heads in the drift and Platteville aquifer system during December 1987 were used to define boundary conditions and calibrate the crosssectional model. Water-level measurements were available from 24 wells located along the selected cross section. The wells were completed in the upper drift $(3$ wells), middle drift ( 10 wells), lower drift ( 3 wells), Platteville ( 6 wells), and St. Peter ( 2 wells) aquifers (fig. 14).

During the winter season, the effect of ground-water withdrawals from the underlying St. Peter and Prairie du Chien-Jordan aquifers on hydraulic heads in the drift and Platteville aquifer system is considered minimal. Hydraulic heads in the St. Peter and Prairie du ChienJordan aquifers rebound and quickly approach steadystate conditions following the lessening of ground-water withdrawals in the late summer and fall. Schoenberg (1984) reported that hydraulic heads in the Prairie du Chien-Jordan aquifer changed less than $5 \mathrm{ft}$ in most of the Minneapolis-St. Paul Metropolitan Area from 197180 and that, despite large ground-water withdrawals, no large cones of depression developed in the potentiometric surface. The winter steady-state potentiometric surfaces in all aquifers represented in the cross-sectional model have a northwest-to-southeast gradient along the cross section, with no significant components of flow normal to the trace of the crosssection.

The initial values of hydraulic properties and fluxes used in the cross-sectional model are listed in table 1. The initial values for horizontal and vertical hydraulic conductivities of the hydrogeologic units in the crosssectional model were based on: (1) reported values from within the study area, (2) Minneapolis-St. Paul Metropolitan Area values reported by Norvitch and others (1974), and (3) grain-size and lithologic descriptions from test holes and well logs in the study area based on the relation between grain size class and hydraulic conductivity as reported by Koch (1980, p. 15). The initial value of recharge to the drift and Platteville aquifer system from infiltration of precipitation, 5.5 in./yr, was based on simulated leakage to the St. Peter aquifer in the St. Louis Park area during the 1970's reported by Stark and Hult (1985). Recharge to the drift and Platteville aquifer system initially was assumed to be similar to leakage to the St. Peter aquifer from overlying deposits. The initial values for porosity of the hydrogeologic units, used in the particle-tracking path line calculation (Pollock, 1989), were derived from mean values reported by Morris and Johnson (1067) and Freeze and Cherry (1979).

The cross-sectional model was calibrated by systematically adjusting the values of horizontal and vertical hydraulic conductivities of the hydroge slogic units and the amount of recharge until calculated hydraulic heads acceptably matched measured vater levels in wells along the cross section. A differ 3 nce of $0.2 \mathrm{ft}$ or less between calculated and n'rasured hydraulic heads was considered an acceptable match. The match between calculated hydraulic heads and measured water levels was improved by (1) adjusting the vertical hydraulic conductivities of the drift confining units within reported ranges, (2) decreasing the vertical hydraulic conductivity of the basal St. Peter confining unit to $0.00002 \mathrm{ft} / \mathrm{d}$, (3) increasing the horizontal hydraulic conductivity of the St. Peter aquifer tc $25 \mathrm{ft} / \mathrm{d}$, and (4) increasing recharge to $6.0 \mathrm{in} . / \mathrm{yr}$. Modelcomputed vertical hydraulic conductivities for the upper and lower drift confining units ranged from 0.01 to 0.04 $\mathrm{ft} / \mathrm{d}$ and from 0.0002 to $5 \mathrm{ft} / \mathrm{d}$, respectively. The values of hydrologic properties resulting in the best fit between calculated hydraulic heads and measured water levels are listed in table 1 as calibrated value. A complete listing of the input data used in the cross-sectional model for the calibrated best-fit simulation is given in the Supplemental Information Section.

The best-fit calculated hydraulic heads generally were within $0.2 \mathrm{ft}$ of measured water levels in vells along the cross section. The differences greater than 0.2 $\mathrm{ft}$ were $+0.3 \mathrm{ft}$ for one well completed in the middle drift aquifer (column 70 of model layer 3 ), $+0.4 \mathrm{ft}$ fcr one well completed in the lower drift aquifer (column 46 of model layer 5 ), and $+0.7 \mathrm{ft}$ for one well completed in the Platteville aquifer (column 46 of model layer 6) (plus $(+)$ indicates that the calculated hydraulic head was higher than the measured water level). The mean difference between calculated hydraulic heads and measured water levels, computed as the algebri ic sum of the differences divided by the number of we'ls, was $+0.06 \mathrm{ft}$, indicating the positive differences were approximately balanced by the negative differences. The mean difference between calculated hydraulic heads and measured water levels, computed as the sum of the absolute values of the differences divided by the number of wells, was $0.18 \mathrm{ft}$.

A number of factors contribute to the differences between calculated hydraulic heads and measured water levels. The calculated hydraulic heads, which represent mean, long-term steady-state conditions, were compared 


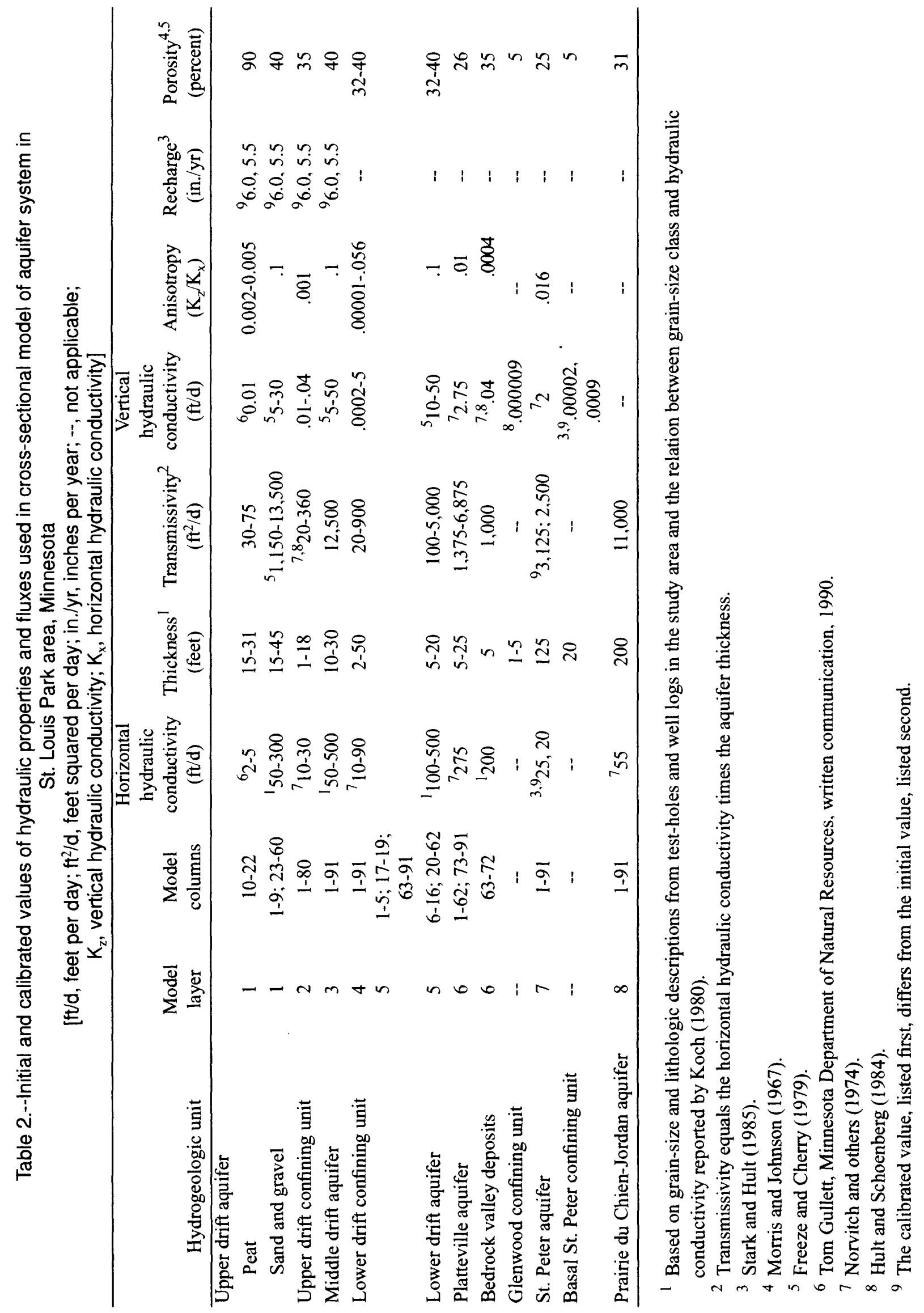


to hydraulic heads measured at a single point in time (December 1987). Although the measured hydraulic heads were assumed to approximate steady-state conditions, annual fluctuations in hydraulic heads do occur. Hydraulic heads measured at a single point in time probably do not precisely represent mean, longterm steady-state conditions. Other factors contributing to differences between calculated hydraulic heads and measured water levels include small-scale spatial variations in the hydraulic properties of the hydrogeologic units and observation wells not being located at the center of cross-sectional model cells.

A steady-state simulation has many solutions that would result in the same distribution of hydraulic heads unless either recharge, discharge, or the hydraulic properties of one of the aquifers is known. The same or similar distribution of hydraulic heads in the aquifer system can be produced by proportionately adjusting hydraulic conductivities in all layers and recharge to the aquifer system.

\section{Computed water budget and flow}

The computed water budget from the cross-sectional model is shown in table 3 . Simulated recharge by precipitation to the uppermost model layers from infiltration accounts for about 41 percent of the total sources of water in the computed water budget, and boundary inflow from the west accounts for about 59 percent. About 66 percent of the simulated recharge enters the upper drift aquifer (model layer 1), about 23 percent enters the upper drift confining unit (model layer 2), and about 11 percent enters the middle drift aquifer (model layer 3 ) at the eastern end of the cross section where the aquifer is unconfined. Boundary inflow to model layer 3, representing the middle drift aquifer, accounts for nearly 32 percent of the total sources of water in the computed water budget. Boundary inflow to the upper drift aquifer (model layer 1), accounts for about 13 percent of the total sources and boundary inflow to the bedrock aquifers (Platteville (model layer 6; columns 1-62 and 73-91), St. Peter (model layer 7), and Prairie du Chien-Jordan (model layer 8)) accounts for about 14 percent. Recharge from infiltration of precipitation accounts for about 45 percent, boundary inflow to the middle drift aquifer accounts for about 36 percent, and boundary inflow to the upper drift and Platteville aquifers accounts for about 19 percent of the total sources of water to the simulated drift and Platteville aquifer system. The drift and Platteville aquifer system consists of model layers 1 to 6 (upper, middle, and lower drift aquifers, upper and lower confining units, and Platteville aquifer).
The only discharges in the computed water tridget are boundary outflows from the eastern end of the crosssectional model. About 70 percent of the bountary outflow occurs through the Platteville (model layer 6; columns 1-62 and 73-91) and St. Peter (model layer 7) aquifers. About 21 percent occurs through the middle drift aquifer (model layer 3). and about 9 percent occurs through the Prairie du Chien-Jordan aquifer (model layer 8).

The general pattern of flow in the drift and Platteville aquifer system may be summarized as: (1) water entering the aquifer system by infiltration of precipitation and boundary inflow from the west. (2) water moving through the aquifer system horizontally to the east in the aquifers and vertically downward through the confining units, and (3) water discharging from the aquifer system by boundary outflow to the east through the middle drift and Platteville aquifers and by leakage downward to the St. Peter aquifer. Downward leakage of ground water through the lower boundary of the model layers in the drift and Platteville aquifer system is similar for each layer (table 4). However, leak $\varepsilon$ ?e is somewhat greater through the lower boundary of model layer 5, representing the lower drift aquifer and lower part of the lower drift confining unit, and somevhat less through the lower boundary of model layer 1 ,

representing the upper drift aquifer, than for the other aquifers. The lower drift aquifer and lower par of the lower drift confining unit are directly underlain by the Platteville aquifer along most of the cross section, with no intervening confining unit, while the upper crift aquifer is underlain by the upper drift confining unit and is of lesser areal extent than the other aquifers.

Discharge from the drift and Platteville aquifer system is by (1) leakage to the underlying St. Peter aquifer (model layer 7), about 40 percent, (2) boundary outflow from the Platteville aquifer (model layer 6; columns 1-62 and 73-91), about 36 percent, and (3) boundary outflow from the middle drift aquifer (model layer 3 ), about 24 percent. The presence or abs ence of the Glenwood confining unit strongly influences the amount of leakage from the drift and Platteville aquifer system to the underlying St. Peter aquifer. Abo it 31 percent of the total leakage of water (through the lower boundary of model layer 6, representing the Platteville aquifer and bedrock valley deposits) to the St. Feter aquifer occurs through the bedrock valley in the eastern part of the cross-sectional model (columns 63 tc 72, fig. 14) where the Platteville aquifer and Glenwood confining unit are absent. West of the bedrock valley in columns 46 to 62 , the Glenwood confining unit is absent or discontinuous. About 99 percent of the total simulated leakage to the St. Peter aquifer occurs through 


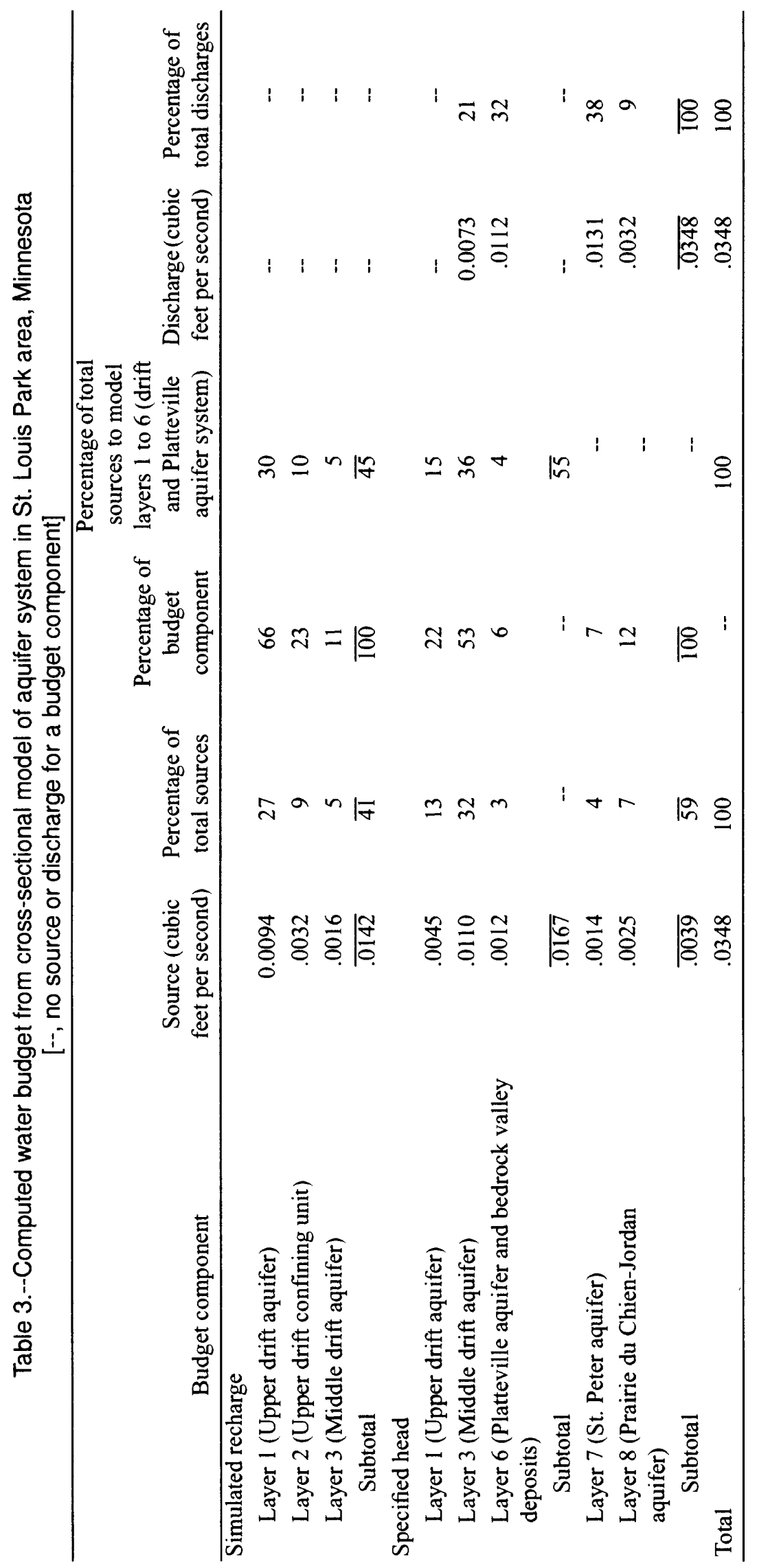


Table 4.--Computed leakage between model layers from cross-sectional model of aquifer system in St. Louis Park area, Minnesota

$[--$, movement of water through the boundary was only downward, with no upward component of flow]

\begin{tabular}{lcc}
\hline Leakage between model layers & $\begin{array}{c}\text { Source (cubic feet } \\
\text { per second) }\end{array}$ & $\begin{array}{c}\text { Discharge (cubic } \\
\text { feet per second) }\end{array}$ \\
\hline Layer I (Upper drift aquifer) & 0.0050 & 0.0189
\end{tabular}

Layer 2 (Upper drift confining unit)

Through upper boundary

$.0189 \quad .0050$

Through lower boundary

.0052

.0223

Layer 3 (Middle drift aquifer)

Through upper boundary

.0223

.0052

Through lower boundary

.0003

.0227

Layer 4 (Upper part of lower drift confining unit)

Through upper boundary

.0227

.0003

Through lower boundary

.0000

.0224

Layer 5 (Lower drift aquifer and lower part of lower drift confining unit)

Through upper boundary

.0224

.0000

Through lower boundary

.0077

.0301

Layer 6 (Platteville aquifer and bedrock valley deposits)

Through upper boundary

.0301

.0077

Through lower boundary

$\begin{array}{ll}-- & .0124\end{array}$

Layer 7 (St. Peter aquifer)

Through upper boundary

.0124

Through lower boundary

$-.0007$

Layer 8 (Prairie du Chien-Jordan aquifer)

.0007

.$\overline{.1477}$

$\overline{.1477}$

the areas where the Glenwood confining unit is absent or discontinuous (columns 46 to 72 ).

A particle-tracking post-processing program (Pollock, 1989) was used to compute ground-water-flow path lines based on output from the calibrated steadystate cross-sectional model. The results of the path-line calculations are graphically represented in figures 16 and 17. The path-line plot shown in figure 16 was generated with particles placed initially on the surface of the uppermost active model layer in every terth column, beginning with column 5 , to represent the movement through the drift and Platteville aquifer system of recharge water derived from the infiltration of precipitation. Most of the recharge to the drift and Platteville aquifer system moves horizontally in the western part of the cross section and discharges fom the aquifer system by boundary outflow and downward leakage to the St. Peter aquifer (model layer 7 ) in the 
eastern part. In column 41 of the cross-sectional model an upward component of flow from the middle drift aquifer to the upper drift aquifer can be seen in figure 16. The limited available hydraulic head data indicate a slight upward vertical gradient $(0.01 \mathrm{ft})$ from the middle drift aquifer to the upper drift aquifer (fig. 14) near the location of the upward component of flow seen in figure 16.

The path-line plot shown in figure 17 was generated with particles placed initially on the left (inflow boundary) face of each model layer representing an aquifer unit (model layer $1,3,6,7$, and 8 ) in column 1 to represent the movement through the drift and Platteville aquifer system of water derived from boundary inflow. The option of tracking particles forward in the direction of ground-water flow was used in both cases. Much of the water derived from boundary inflow discharges by downward leakage to the St. Peter aquifer (model layer 7) prior to reaching the bedrock valley. The predominant flow is initially horizontal within the aquifer units, but then becomes nearly vertical through the confining units. The vertical leakage of water through the upper part of the lower drift confining unit (model layer 4) occurs mainly west of column 22 where the unit is only about $2 \mathrm{ft}$ thick. The steep slope of the path lines in the St. Peter aquifer, beginning in column 46 , reflect the absence of the Glenwood confining unit in columns 46 to 72 . The greatly increased leakage to the St. Peter aquifer, because of the absence of the Glenwood confining unit, probably results in an increased vertical hydraulic head gradient in the aquifer. No measured hydraulic heads for the St. Peter aquifer are available to verify the head gradient, except near the western edge of the discontinuity in the confining unit.

The path-line plots illustrate the major directions of flow in the drift and Platteville aquifer system as (1) predominantly horizontal flow in the aquifers, (2) predominantly vertical flow in the confining units, and (3) significant leakage of ground water from the drift and Platteville aquifer system to the underlying St. Peter aquifer (model layer 7 ) in the eastern part of the cross section where the Glenwood confining unit is absent. About 48 percent of the downward leakage of water through the upper part of the lower drift confining unit (model layer 4) also occurs in the eastern part of the cross section because the till and clay comprising the unit is sandier than it is in the western part. The vertical hydraulic conductivity of the lower drift confining unit is therefore greater in the eastern part.

\section{Model response to changes in representetion of hydraulic properties and representation of hydrogeologic units}

Model response to changes in representation of hydraulic properties of hydrogeologic units, recharge, and boundary conditions and to variations in hypothetical hydrologic conditions was investigated. Model simulations were done by changing the simulated hydraulic properties of hydrogeologic units and recharge to identify the relative effect of changes in hydraulic properties and recharge on calculated hydraulic heads and simulated ground-water flow. Model simulations were also done by using diffe"ent boundary conditions than those used in the calibrated model. The type of boundary condition used mav' have significant effects on calculated hydraulic heads and simulated ground-water flow and these effects need to be considered. Model response to variations in hypothetical hydrologic conditions was investigated by varying the simulated hydraulic properties and physical extent of confining units. The simulations (1) provide a better understanding of the role of confining units in the ground-water-flow system, and (2) illustrate the effects of possible errors in representing the drift and Platteville aquifer system due to uncertainty regarding the er tent of the Glenwood confining unit.

\section{Changes in representation of hydraulic properties and recharge}

A model-sensitivity analysis was done, where:n the value of a single hydrologic property is varied while all other properties are held constant. The degree to which the hydrologic properties can be adjusted is related to the uncertainty as to the correct or true value associated with each property. For example, the range of val ies for horizontal hydraulic conductivity of each aquifer unit is, on the basis of grain-size and lithologic descriptions and published reports for the Minneapolis-St. Paul Metropolitan Area, relatively small (about 50 to 200 percent of the initial values used in the model); therefore, the uncertainty as to the correct or true value is relatively small. In contrast, the confining units have a wide range in values of vertical hydraulic conductivities, on the basis of values given in published reports and textbooks for confining unit materials, spanning 2 or 3 orders of magnitude; therefore, the uncertainty as to their correct value is large. Variations of hydrologic properties were kept within reported or plausible ranges of values (tables 5 and 6). Horizontal hydraulic conductivities and transmissivities of the model layers were varied by factors of 1.5 and 0.5 (table 5 ). The vertical leakance terms controlling leakage between layers were varied by factors of 10 and 0.1 (table 6). Variations in the vertical leakance terms 
C

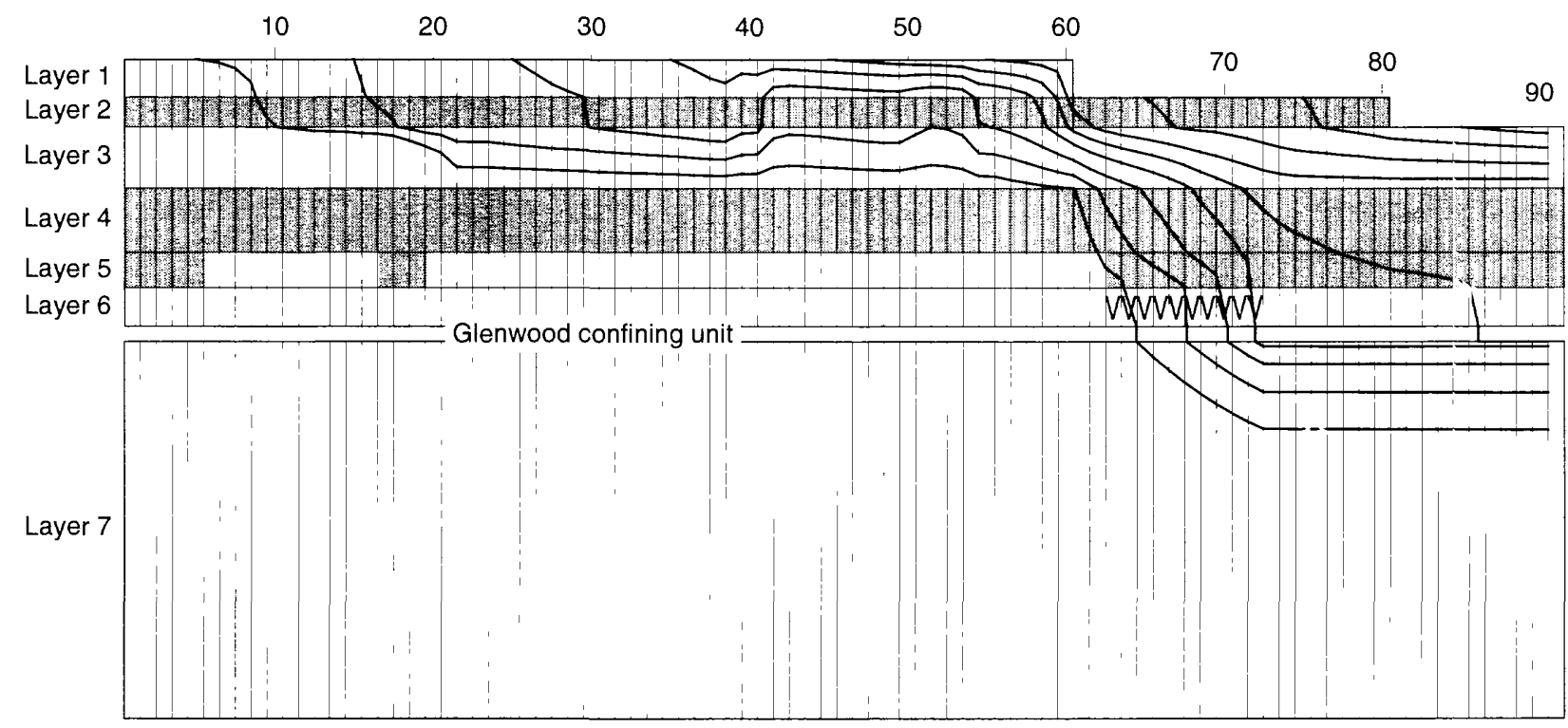

Basal St. Peter confining unit

Layer 8

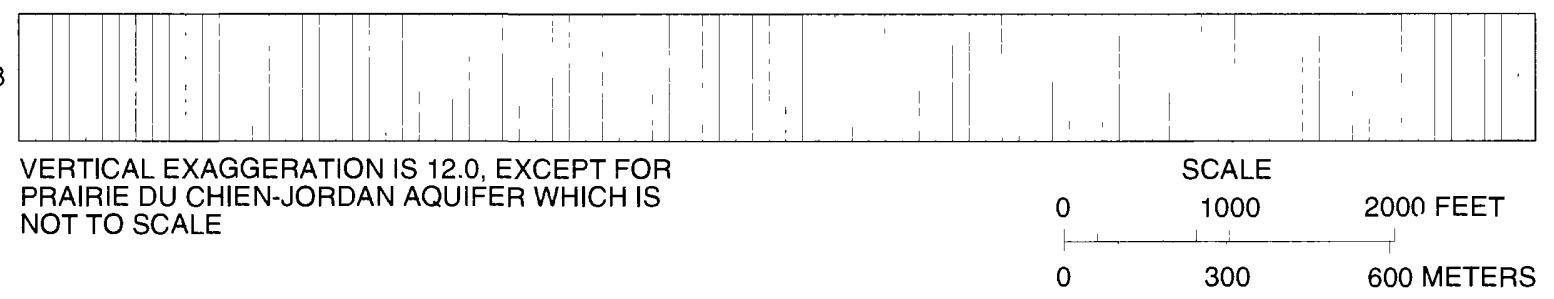

\section{EXPLANATION}

Layers represent hydrogeologic units:

Layer 1 -- Upper drift aquifer

Layer 2 -- Upper drift confining unit

Layer 3 -- Middle drift aquifer

Layer 4 -- Upper part of the lower drift confining unit

Layer 5 -- Lower drift aquifer and lower part of the lower drift confining unit

Layer 6 -- Platteville aquifer and bedrock valley deposits

Layer 7 -- St. Peter aquifer

Layer 8 -- Prairie du Chien-Jordan aquifer

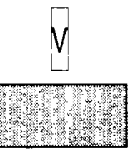

Cell representing Bedrock valley deposits

Confining unit

Particle path-lines -- Forward tracking from the recharge (land) surface.

Figure 16. Path-line plot representing movement through the drift and Platteville aquifesystem of recharge water derived from the infiltration of precipitation, St. Louis Park area, Minnesota (trace of section shown in figure 3). 
C

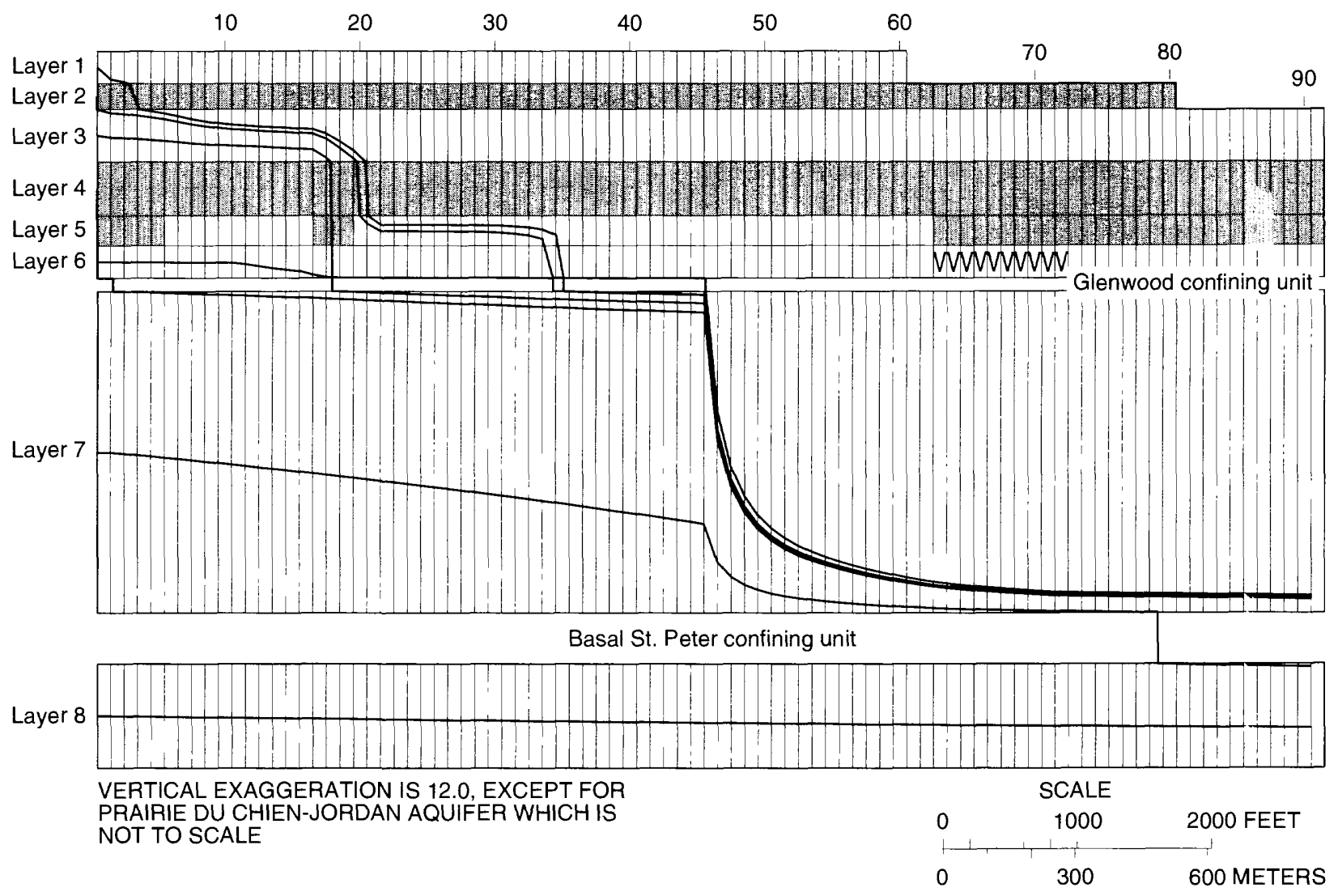

\section{EXPLANATION}

Layers represent hydrogeologic units:

Layer 1 -- Upper drift aquifer

Layer 2 -- Upper drift confining unit

Layer 3 -- Middle drift aquifer

Layer 4 -- Upper part of the lower drift confining unit

Layer 5 -- Lower drift aquifer and lower part of the lower drift confining unit

Layer 6 -- Platteville aquifer and bedrock valley deposits

Layer 7 -- St. Peter aquifer

Layer 8 -- Prairie du Chien-Jordan aquifer

V Cell representing Bedrock valley deposits

Confining unit

Particle path-lines -- Forward tracking from the boundary inflow surface.

Figure 17. Path-line plot representing movement through the drift and Platteville aquifer system of water derived from boundary inflow, St. Louis Park area, Minnesota (trace of section shown in figure 3 ). 
correspond to variations in the vertical hydraulic conductivity of the confining units because the vertical hydraulic conductivities of the confining units are much smaller than the vertical hydraulic conductivities of the aquifers. Recharge was varied by factors of 1.333 and 0.667 , which correspond to plus and minus $2.0 \mathrm{in} . / \mathrm{yr}$ (table 5).

The sensitivity analyses indicate that calculated hydraulic heads in the simulated drift and Platteville aquifer system were most sensitive to variations in (1) horizontal hydraulic conductivities of the middle drift aquifer, (2) transmissivities of the Platteville and St. Peter aquifers, (3) vertical hydraulic conductivities of the lower drift confining unit, (4) vertical hydraulic conductivity of drift material filling the bedrock valley where the Platteville aquifer and Glenwood confining unit are absent, (5) vertical hydraulic conductivity of the basal St. Peter confining unit, and (6) recharge. Varying the horizontal hydraulic conductivities of the middle drift aquifer (model layer 3 ) or the transmissivities of the Platteville aquifer and bedrock valley deposits (model layer 6) or the St. Peter aquifer (model layer 7) by factors of 1.5 and 0.5 resulted in mean differences in calculated hydraulic heads in the drift and Platteville aquifer system of 0.1 to $0.5 \mathrm{ft}$ (table 5), with a range in differences from 0 to $1.0 \mathrm{ft}$.

The general effect of increasing the horizontal hydraulic conductivities of the upper drift aquifer (model layer 1 ) or of the middle drift aquifer (model layer 3 ) was to increase the net horizontal boundary flow to these aquifers by about 16 and 53 percent (table 5 ), respectively, thereby resulting in higher calculated hydraulic heads in the model. The net horizontal boundary flow represents the difference between western boundary inflow and eastern boundary outflow for a model layer. Although the horizontal net boundary flow for a model layer does not equal zero, the total fluxes into and out of a model layer are equal (net flux equals zero), as required for a steady-state simulation. The general effect of increasing the transmissivities of the Platteville aquifer and bedrock valley deposits (model layer 6) or the St. Peter aquifer (model layer 7) was to decrease the net horizontal boundary flow to these aquifers (by increasing the eastern boundary outflow) by about 15 and 24 percent (table 5), respectively, thereby resulting in lower calculated hydraulic heads in the model. The general effect of decreasing the horizontal hydraulic conductivities or transmissivities of the aquifer units (varying only one hydrologic property for one model layer at a time) was to decrease the net horizontal boundary flow, with a net loss in horizontal flow of 28 and 81 percent to the aquifer, for the upper drift and middle drift aquifers, respectively. Net horizontal boundary flow was increased, with a net gain in horizontal flow of 25 and 37 percent to the aquifer, for the Platteville and $\Sigma t$. Peter aquifers, respectively.

Calculated hydraulic heads in the drift and Platteville aquifer system were significantly affected by varying the vertical hydraulic conductivities of the upper drift confining unit or the lower drift confining unit $0^{-}$the drift material filling the bedrock valley by factors of 10 and 0.1 . Increasing the vertical hydraulic condurtivity of the basal St. Peter confining unit b:' a factor of 10 also significantly affected calculated hydraulic heads Mean differences in calculated hydraulic heads for the aquifers varied from less than 0.05 to $1.0 \mathrm{ft}$, with a range in differences from 0.0 to $4.8 \mathrm{ft}$ (table 6). The largest calculated differences occurred in the upper drift aquifer (model layer 1) and in the eastern part of the cross section near the bedrock valley. Decreasing the vertical hydraulic conductivity by a factor of 0.1 generally resulted in much larger deviations from the calit rated best-fit hydraulic heads than did increasing the vertical hydraulic conductivity by a factor of 10 . The general effect of increasing the vertical hydraulic conductivity of a confining unit (that is, increasing the vertic $\boldsymbol{c}^{1}$ leakance term for adjacent layers) was to lower calculated hydraulic heads in the aquifers above the confining unit and to raise calculated hydraulic $l$ sads in the aquifers below the confining unit. The general effect of decreasing the vertical hydraulic conductivity of a confining unit was to raise calculated hydraulic l a ads in the aquifers above the confining unit and to lower calculated heads in the aquifers below the confining unit.

The percentage increase in net flux across the lower boundary of an aquifer from the calibrated best-fit simulation resulting from increasing the vertical hydraulic conductivity of an adjacent confining unit ranged from about 2 percent for the middle drift aquifer (model layer 3 ) to about 884 percent (nearly 9 times the calibrated best-fit value) for the St. Peter aquifer (model layer 7) (table 6). The percentage increase for the St. Peter aquifer is large because the net flux across the underlying basal St. Peter confining unit for the calibrated best fit simulation was small, only about 0.05 times the net flux across the lower boundary of the other aquifers, due to the low vertical hydraulic conductivity of the confining unit. The effect of the increased flow across the lower boundary of the St. Peter aquifer on hydraulic heads in the drift and Platteville aquifer system is small, resulting in changes in hydraulic heads of $0.3 \mathrm{ft}$ or less. The percentage decrease in net flux across the lower boundary of an aquifer that res alted from decreasing the vertical hydraulic conductivity of a 


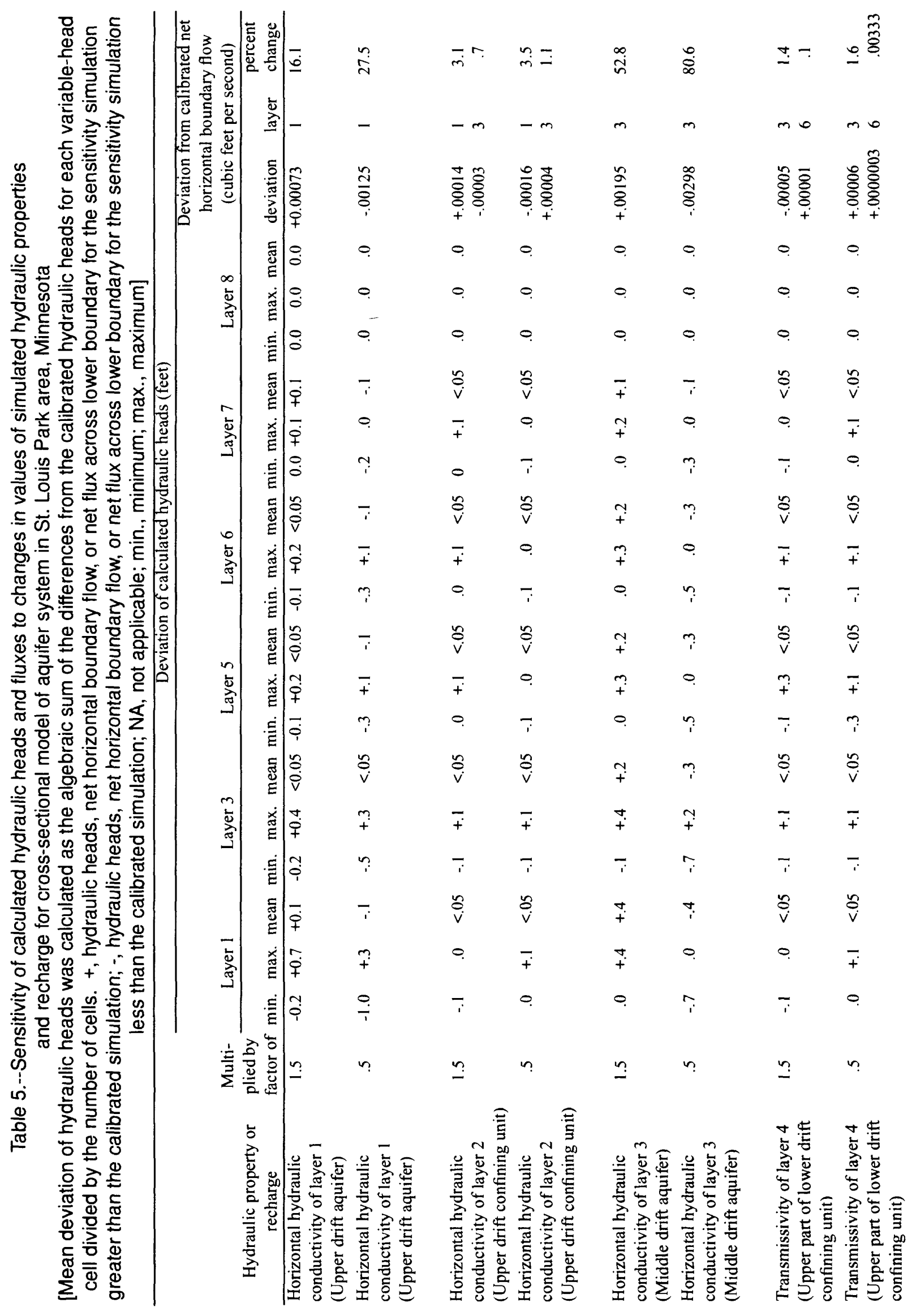




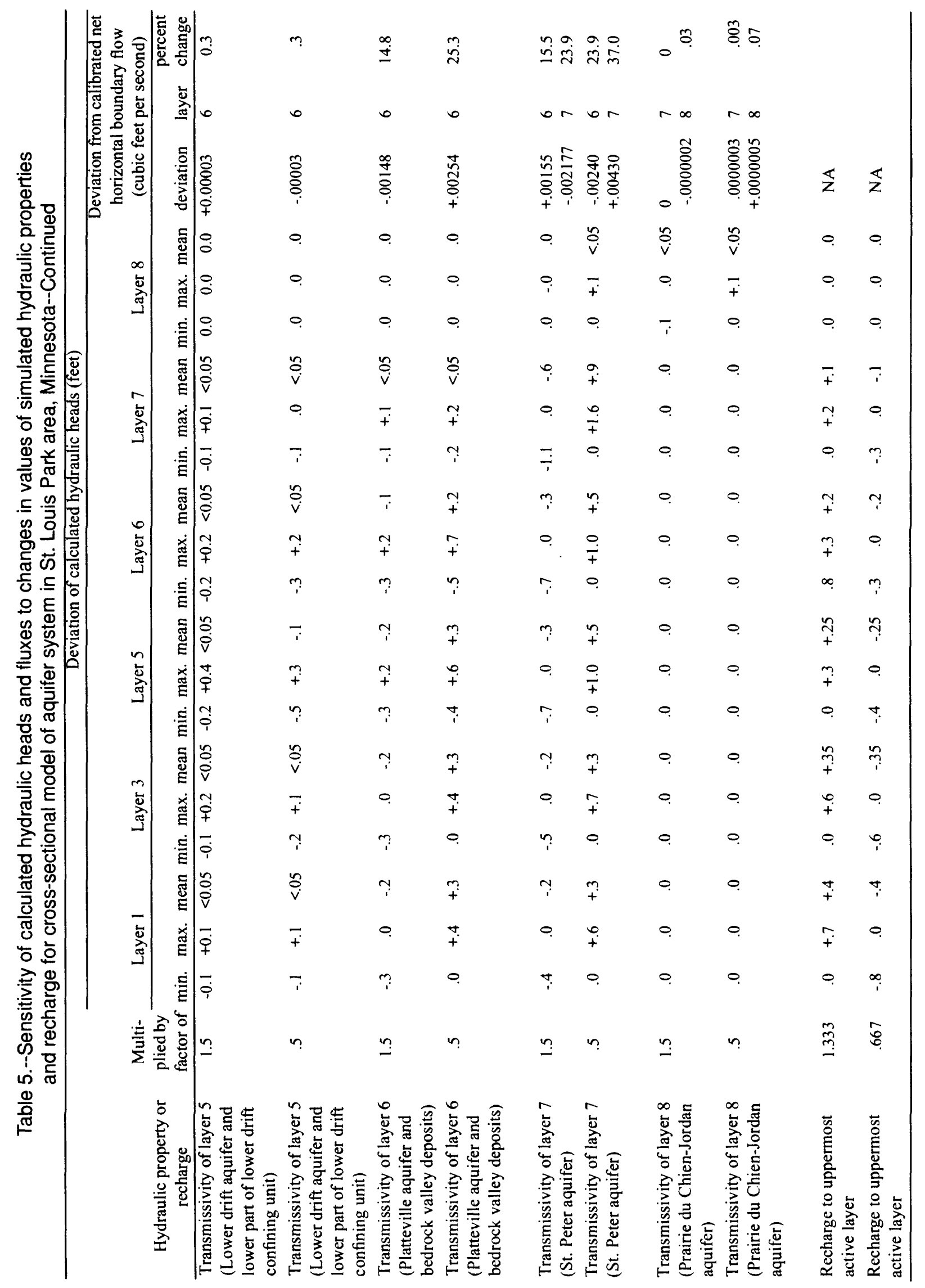




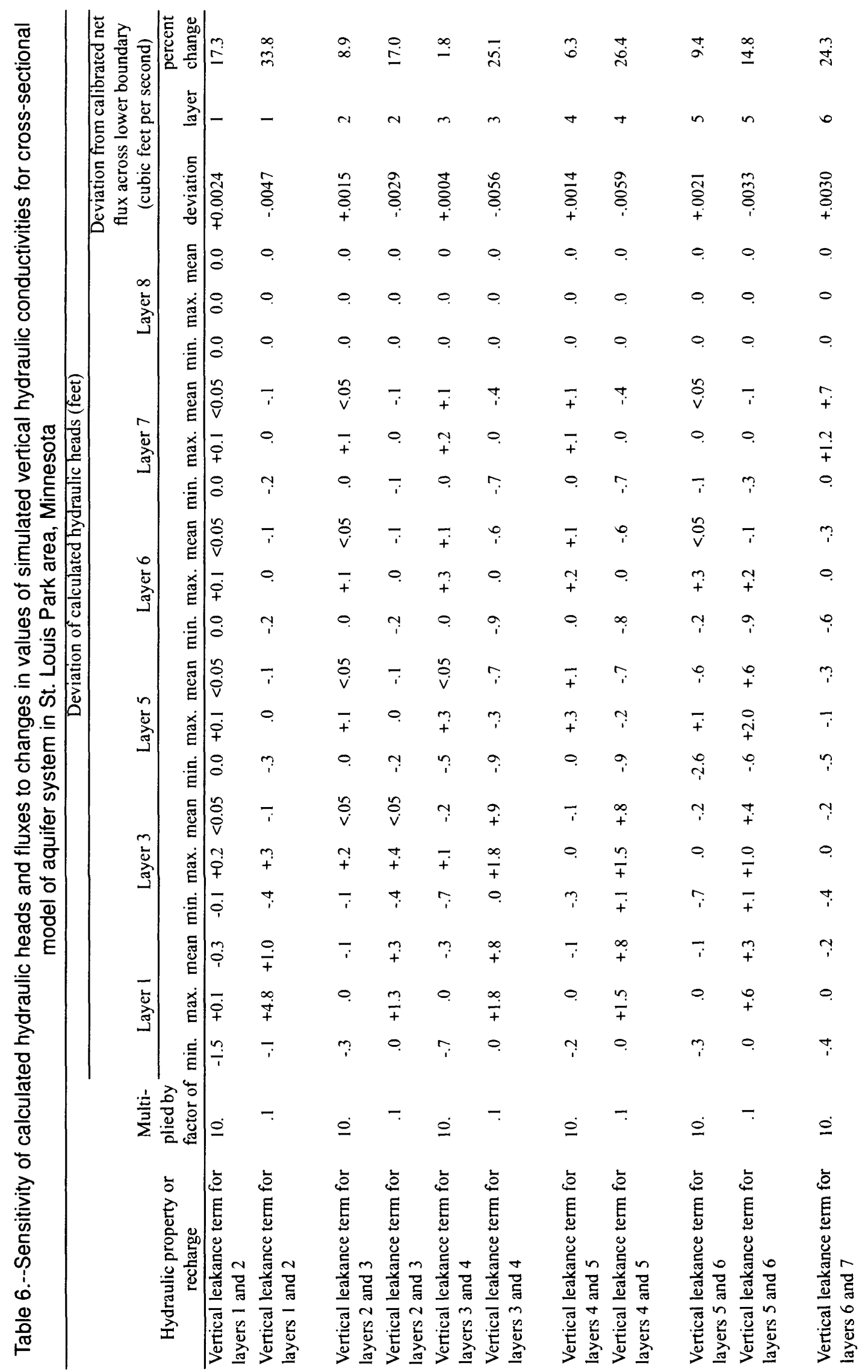




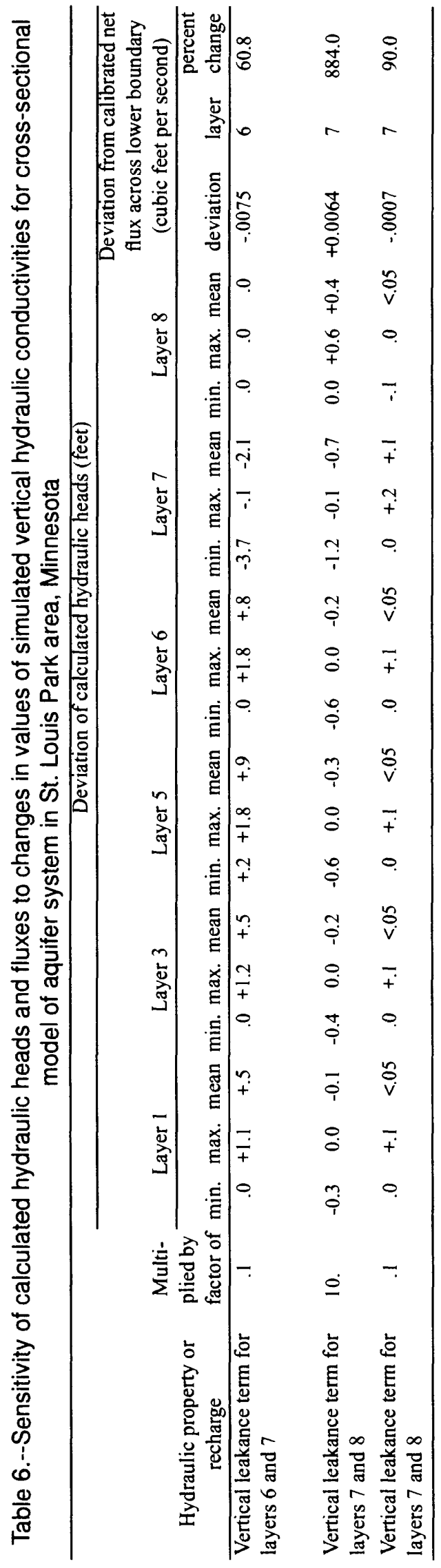


confining unit ranged from about 15 percent for the lower drift aquifer and lower part of the lower drift confining unit (model layer 5) to about 90 percent for the St. Peter aquifer (model layer 7). The largest changes in net flux across the lower boundary of the lower drift aquifer and lower part of the lower drift confining unit (model layer 5) and the Platteville aquifer and bedrock valley deposits (model layer 6) resulting from variations in vertical leakance terms occur in and near the bedrock valley.

The sensitivity analysis indicated the cross-sectional model steady-state hydraulic heads changed by $0.3 \mathrm{ft}$ or less in most cases in response to large variations in the hydraulic properties of the hydrogeologic units. The imposed variations, however, did have a significant effect on simulated ground-water flow in the drift and Platteville aquifer system. The direction and magnitude of ground-water flow is of primary interest in assessing the results of the sensitivity analysis. Varying the vertical hydraulic conductivities of the confining units, in particular, had significant effects on ground-water flow, and therefore migration of contaminants, in the aquifer system. The implications of the results of the model analysis for migration of contaminants is discussed later in the report. The results of the sensitivity analysis indicate that the most important additional information needed to better simulate the drift and Platteville aquifer system in the study area is an improved definition, in terms of extent and hydraulic properties, of the confining units.

Varying recharge to the drift and Platteville aquifer system (applied to the uppermost active model layer) by factors of 1.333 and $0.667( \pm 2.0 \mathrm{in}$./yr) resulted in mean differences in calculated hydraulic heads of 0.2 to $0.4 \mathrm{ft}$, with a range in differences from 0.0 to $0.8 \mathrm{ft}$ (table 5). The sensitivity of calculated hydraulic heads, in the cross-sectional model, to variations in recharge is lessened by the influence of the specified-head boundaries for the aquifer units. Ground-water inflow from the west is a significant source of water to the aquifer system in the study area, about 59 percent based on the computed water budget from the cross-sectional model. Decreased simulated recharge resulted in increased simulated boundary inflow through the western boundaries of the aquifer units. Figure 17 illustrates the predominant flow paths of water derived from boundary inflow. In contrast, figure 16 illustrates the predominant flow paths of water derived from recharge.

\section{Changes in representation of boundary conditions}

The effects of using specified-head boundary conditions on calculated hydraulic heads and ground- water flow in the drift and Platteville aquifer system were investigated by substituting no-flow boundaries for specified-head boundaries and comparing the results. The changes in calculated hydraulic heads for ea-h model layer that resulted from the substitution of noflow boundaries for specified-head boundaries at the western boundary (where ground-water inflow tc the drift and Platteville aquifer system occurs) are given in table 7.

Calculated hydraulic heads in the drift and Platteville aquifer system were most affected by changes in the representation of the boundary condition for the middle drift aquifer (model layer 3 ), with mean declines ranging from 0.5 to $0.9 \mathrm{ft}$. Calculated hydraulic haads in the drift and Platteville aquifer system (model layers 16) were least affected by changes in the boundary conditions for the underlying bedrock aquifers ( $\mathrm{S}^{*}$. Peter and Prairie du Chien-Jordan aquifers, model layers 7 and 8), with mean declines equal to or less than $0.1 \mathrm{ft}$. The calculated hydraulic head declines for a given model layer were greatest near the western boundary of the cross-sectional model and generally decrease- to almost zero near the eastern boundary of the model. The simulations indicated that the type of boundary condition imposed at the western boundary of the crosssectional model had a significant effect on hydraulic heads in the drift and Platteville aquifer system, particularly for changes in the type of boundary condition used for the middle drift aquifer and for the western part of the cross section.

The western boundary of the cross-sectional model was changed to a no-flow boundary for all the model layers, with recharge from precipitation as the orly source of water. The change in boundary conditions resulted in 57 percent of the model layer cells representing the upper drift aquifer (model layer 1) becoming desaturated. Mean declines in calculated hydraulic heads in the other aquifer units ranged from $0.9 \mathrm{ft}$ in the Prairie du Chien-Jordan aquifer (model layer 8 ) to $7.5 \mathrm{ft}$ in the middle drift' aquifer (model layer $3)$.

When the western boundary condition of a mcdel aquifer layer was changed from a specified-head to a noflow boundary the main effect on simulated groundwater flow was to increase the inflow through the western boundaries of the other layers representing aquifer units. Changing the western boundary of the middle drift aquifer (model layer 3 ) resulted in the greatest increases in boundary inflow to the other aquifers because ground-water inflow to the middle drift aquifer was much greater than to the other aquifers. Inflow was increased as much as 325 percent in the 


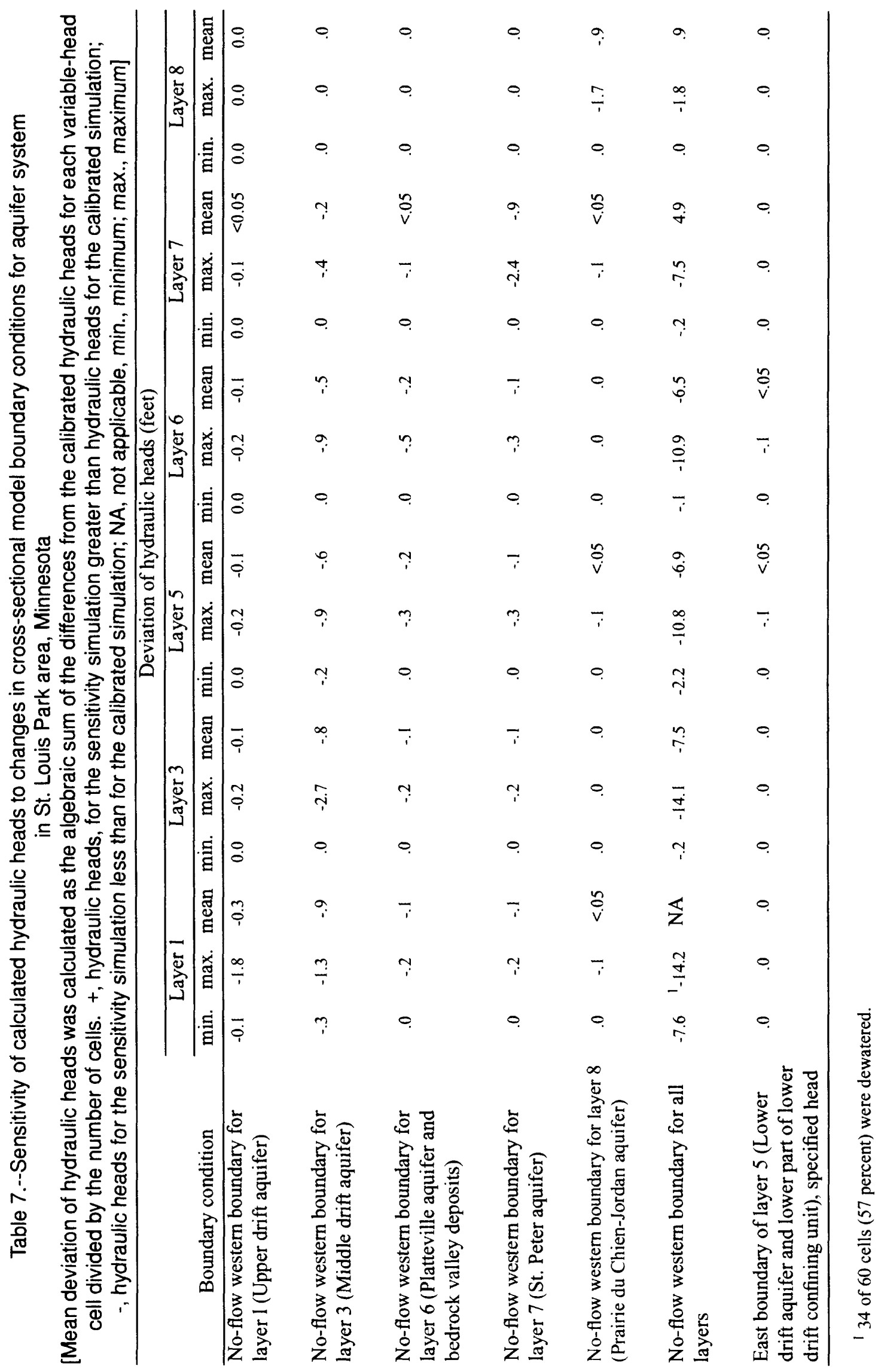


Platteville aquifer and bedrock valley deposits (model layer 6). Boundary outflow through the eastern boundary of an aquifer unit decreased by a small amount (about 7 percent or less) as a result of the imposed boundary condition change on the western boundary. Changing the western boundary condition of a model layer representing an aquifer also resulted in greater leakage of water down from overlying aquifer units (increases of about 10 to 25 percent). In summary, the volume of water lost to the aquifer system by eliminating boundary inflow to an aquifer unit was compensated for by (1) boundary inflow to the other aquifer units, and (2) to a lesser degree, reduced boundary outflow and increased leakage of water down from overlying aquifer units.

The effects of changing the eastern boundary of model layer 5, representing the lower drift aquifer and lower part of the lower drift confining unit, from a noflow to a specified-head boundary on calculated hydraulic heads and simulated ground-water flow also were investigated (table 7). Changing the boundary condition from no-flow to a specified-head resulted in no significant change in calculated hydraulic heads $(0.1$ $\mathrm{ft}$ or less). The resultant simulated boundary outflow for model layer 5 also was not significant in relation to total flow (about $0.0001 \mathrm{ft} / \mathrm{s}$ ), and leakage to the underlying Platteville aquifer and bedrock valley deposits (model layer 6) was reduced by less than 1 percent.

\section{Hypothetical hydrologic conditions}

The calibrated steady-state cross-sectional model was used to investigate the effects of varying the hydraulic properties of confining units and the physical extent of the Glenwood confining unit on calculated hydraulic heads and simulated ground-water flow in the drift and Platteville aquifer system. The variations included (1) increasing the vertical hydraulic conductivity of the upper part of the lower drift confining unit (model layer 4) by a factor of 100 in the western part (columns 1 to $60)$ of the cross-section, (2) making the Glenwood confining unit continuous in the area west of the bedrock valley (columns 46 to 62), (3) making the Glenwood confining unit continuous across the bedrock valley (columns 63 to 72 ), and (4) making the Glenwood confining unit continuous along the entire cross section. The distribution and hydraulic properties of confining units are of major importance to groundwater flow and the potential transport of contaminants near the plant site.

In the simulations of hypothetical hydrologic conditions, the hydraulic properties and physical extent of the confining units that most affected ground-water flow were varied: these units are the upper part of the lower drift confining unit (model layer 4 ) and the Glenwood confining unit. The effects of increased vertical leakage preferentially in the western part of the cross section and the effects of changes in the loration and extent of the bedrock valley on hydraulic herds and ground-water flow were evaluated.

The vertical hydraulic conductivity of the upper part of the lower drift confining unit (model layer 4) was increased by a factor of 100 in the western part (columns 1 to 60 ) of the cross section. This resulted in a mean deviation from the calculated hydraulic heads from the calibrated best-fit simulation of (1) $-0.8 \mathrm{ft}$ and $0.5 \mathrm{ft}$ in the overlying upper drift aquifer (model layer 1) and middle drift aquifer (model layer 3), respectively; and (2) in the underlying lower drift aquifer and lower part of the lower drift confining unit (model layer 5), Platteville aquifer and bedrock valley deposits (model layer 6), and St. Peter aquifer (model layer 7 ), th $*$ mean deviations ranged from +0.4 to $+0.6 \mathrm{ft}$ (table 8 ).

As a result of increasing the vertical hydraulis conductivity of the upper part of the lower drift confining unit by a factor of 100 in the western part of the cross section, the net horizontal boundary flow for the middle drift aquifer (model layer 3 ) increased by about 59 percent (table 9 ). The horizontal hydraulic gradient in the middle drift aquifer at the western boundary increased and inflow at the western bcindary increased by 20 percent. The net horizontal boundary flow for the Platteville aquifer and bedrock valley deposits (model layer 6) decreased by about 11 percent. The horizontal hydraulic gradient in the Platteville aquifer at the western boundary decreased because of greater leakage through the overlying confining unit. Inflow at the western boundary decreased by 48 percent because of the change in slope of the horizontal hydraulic gradient. The net vetical flux across the lower boundary of the upper part of the lower drift confining unit (model layer 4 ) increased by about 11 percent. The leakage of water from the drift and Platteville aquifer system (model layers 1 tc 6 ) to the underlying St. Peter aquifer (model layer 7 ) through the bedrock valley (columns 63 to 72) decreased by about 10 percent. Increased vertical leakage of water through the drift and Platteville aquifer system to the St. Peter aquifer in the western part of the cross section is accompanied by decreased leakage to the St. Peter aquifer through the bedrock valley. A widening of the area of vertical leakage through the upper part of the lower drift confining unit (model layer 4) to the west to include columns 57 to 60 (fig. 18) is apparent when compared to figure 16 for the calibrated best-fit simulation. 


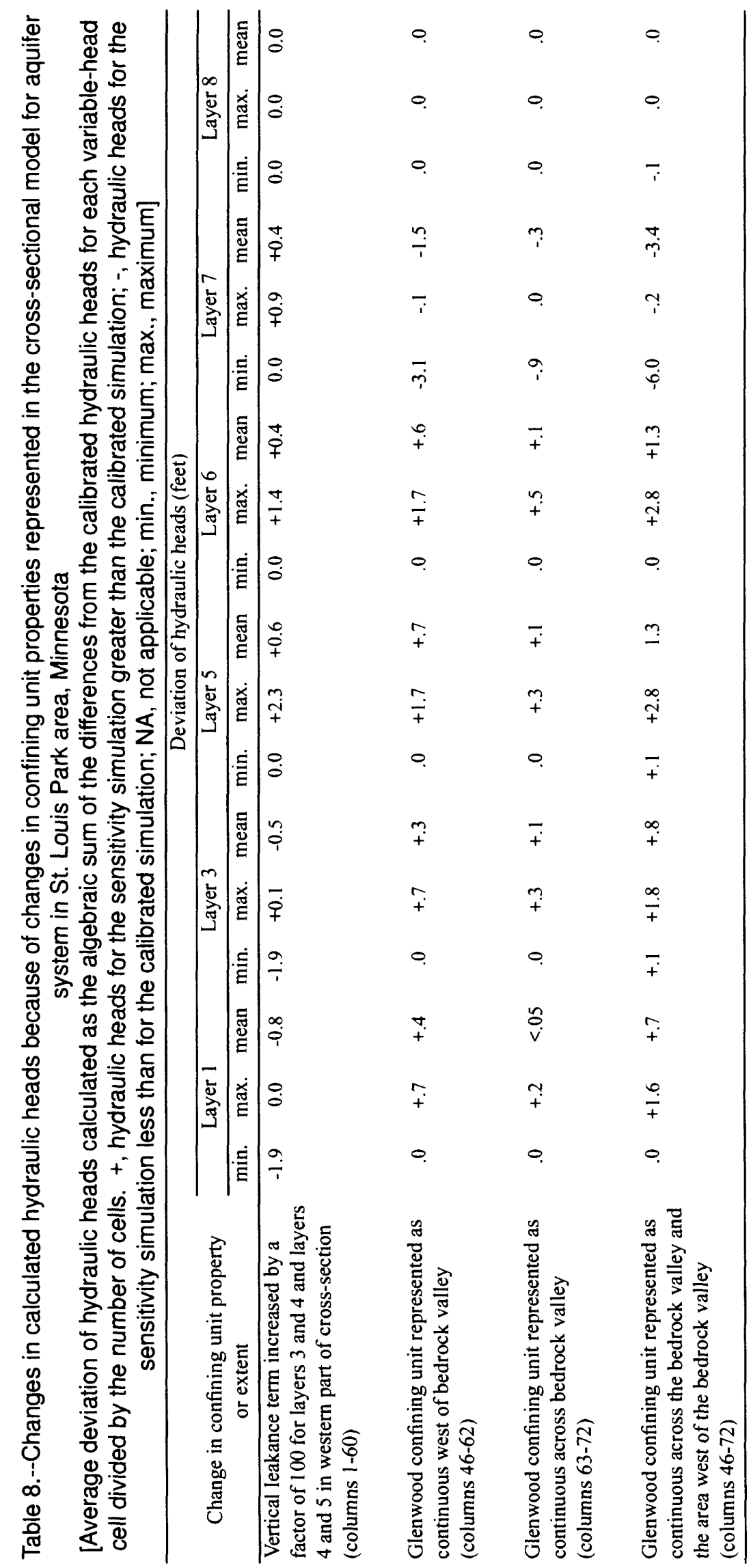


The effect of varying the areal extent of the Glenwood confining unit and the bedrock valley on calculated hydraulic heads and simulated ground-water flow in the drift and Platteville aquifer system was investigated. This was done by varying the representation of the areal extent of the Glenwood confining unit in the cross-sectional model. The Glenwood confining unit is absent in an area immediately to the west of and through the bedrock valley, allowing the Platteville aquifer to directly overlie the St. Peter aquifer. In the model the Glenwood confining unit is not represented in columns 46 to 72 . A hypothetical extension of the confining unit was simulated by decreasing the vertical hydraulic conductivity used in the vertical leakance term calculation for model layers 6 and 7 to $.00001 \mathrm{ft} / \mathrm{d}$ in columns 46 to 62 . The same hydrologic conditions at the eastern cross-sectional model boundary were imposed as for the calibrated best-fit simulation. A specified-head boundary condition was used for the eastern boundaries of the upper part of the lower drift confining unit (model layer 4) and the lower drift aquifer and lower part of the lower drift confining unit (model layer 5) and specified-head values corresponding to the calibrated best-fit hydraulic heads were used. Simulating a hypothetical extension of the Glenwood confining unit west of the bedrock valley resulted in mean rises in calculated hydraulic heads in the drift and Platteville aquifer system (model layers 1-6) ranging from $0.3 \mathrm{ft}$ in the middle drift aquifer (model layer 3 ) to $0.7 \mathrm{ft}$ in the lower drift aquifer and lower part of the lower drift confining unit (model layer 5) (table 8). Calculated hydraulic heads in the St. Peter aquifer (model layer 7) were 0.1 to $3.1 \mathrm{ft}$ lower, with the mean decrease for the aquifer being $1.5 \mathrm{ft}$.

As a result of simulating a hypothetical extension of the Glenwood confining unit in columns 46 to 62 , the net horizontal boundary flow for the Platteville aquifer and bedrock valley deposits (model layer 6) decreased by about 18 percent (table 9 ). Eastern boundary outflow from model layer 6 , representing the Platteville aquifer and bedrock valley deposits, increased by 5 percent and the amount of water leaking to the underlying St. Peter aquifer (model layer 7) decreased about 35 percent. The net horizontal boundary flow for model layer 7 . representing the St. Peter aquifer, increased by about 37 percent. Eastern boundary outflow from model layer 7 decreased by 15 percent. The amount of water leaking from the drift and Platteville aquifer system (model layers 1-6) to the St. Peter aquifer (model layer 7) through the bedrock valley more than doubled (increased by about 108 percent. table 7), even though the total amount of water leaking from the drift and
Platteville aquifer system to model layer 7, representing the St. Peter aquifer, decreased by about 35 percent. The additional leakage of water to the underlying St. Peter aquifer through the bedrock valley in the simulation resulted from water being impeded from leaking downward west of the bedrock valley by the simulated extension of the Glenwood confining unit.

A second hypothetical variation of the extent of the Glenwood confining unit was simulated. In this simulation the vertical hydraulic conductivity us $: d$ in the vertical leakance term calculation for model layers 6 and 7 was decreased to $.00001 \mathrm{ft} / \mathrm{d}$ in columns 63 to 72 . In effect, the Glenwood confining unit was modeled as underlying the bedrock valley. This simulation resulted in mean rises in calculated hydraulic heads in the drift and Platteville aquifer system (model layers 1-6) of about $0.1 \mathrm{ft}$, with deviations from calibrated best-fit hydraulic heads ranging from 0 to $0.5 \mathrm{ft}$ (table 8). Calculated hydraulic heads in the St. Peter aquifer (model layer 7) were 0 to $0.9 \mathrm{ft}$ lower, with the mean decrease for the aquifer being $0.3 \mathrm{ft}$.

As a result of simulating a hypothetical extension of the Glenwood confining unit in columns 63 to 72 ., the net horizontal boundary flow for the Platteville a nuifer and bedrock valley deposits (model layer 6) decreased by about 9 percent (table 9). Eastern boundary outflow from model layer 6, representing the Platteville a quifer and bedrock valley deposits, increased by 8 percent and the amount of water leaking to the underlying St. Peter aquifer (model layer 7) decreased by about 14 percent. The leakage of water from the drift and Platteville aquifer system (model layers 1-6) to model layer 7 , representing the St. Peter aquifer, that was calculated as occurring through the bedrock valley was greatly reduced (decreased by 99.8 percent, table 9 ). As a result, the water that was impeded from leaking downward through the bedrock valley discharged from the drift and Platteville aquifer system by easterr boundary outflow. Net horizontal boundary flow for model layer 7, representing the St. Peter aquifer, increased by about 15 percent, and eastern boundary outflow from model layer 7 decreased by 12 percent.

A third hypothetical variation of the extent of the Glenwood confining unit was simulated by decreasing the vertical hydraulic conductivity used in the vertical leakance term calculation for model layers 6 and 7 to $0.00001 \mathrm{ft} / \mathrm{d}$ in columns 46 to 72 ; this, in effect, made the Glenwood confining unit continuous along the entire cross section. This simulation resulted in mean rises in calculated hydraulic heads in model layers 1 to 6 , representing the drift and Platteville aquifer system, ranging from $0.7 \mathrm{ft}$ in the upper drift aquifer (motel 


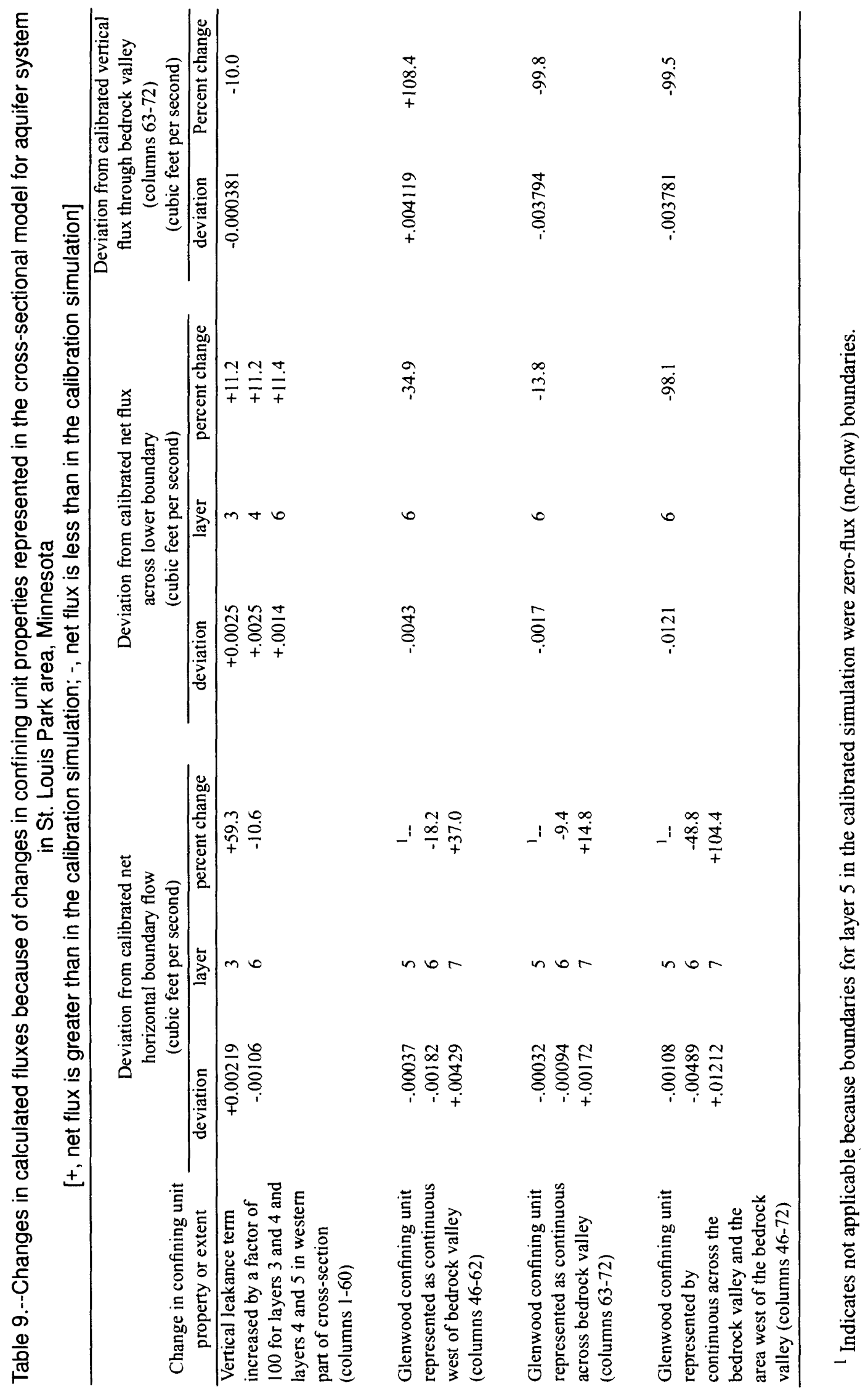


C

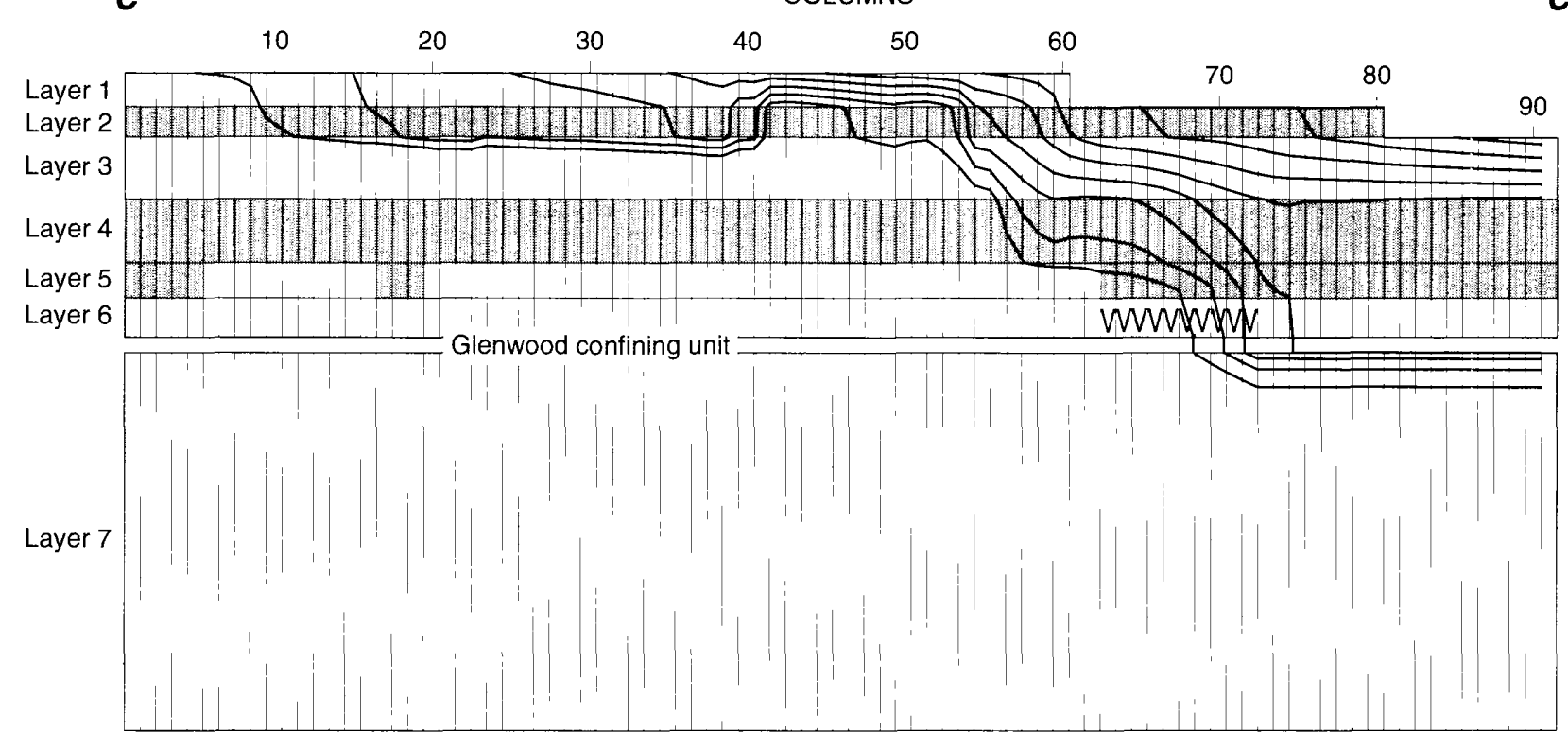

Basal St. Peter confining unit

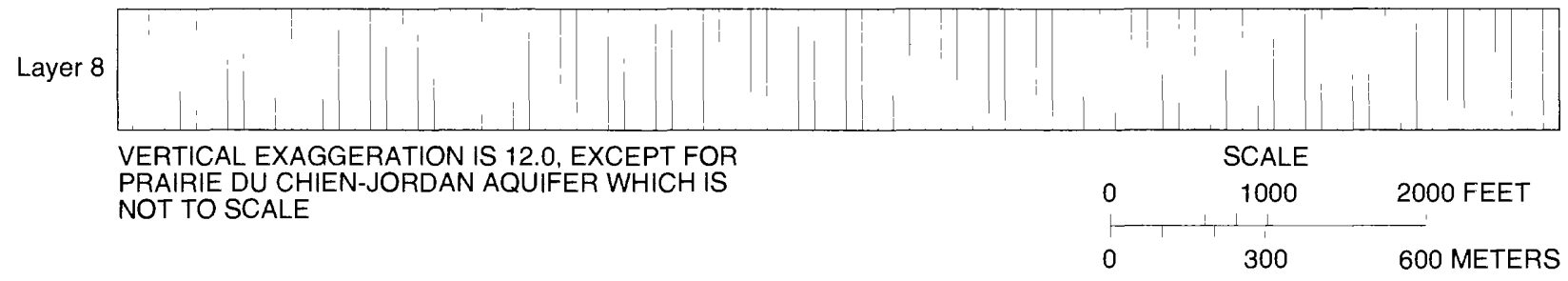

\section{EXPLANATION}

Layers represent hydrogeologic units:

Layer 1 -- Upper drift aquifer

Layer 2 -- Upper drift confining unit

Layer 3 -- Middle drift aquifer

Layer 4 -- Upper part of the lower drift confining unit

Layer 5 -- Lower drift aquifer and lower part of the lower drift confining unit

Layer 6 -- Platteville aquifer and bedrock valley deposits

Layer 7 -- St. Peter aquifer

Layer 8 -- Prairie du Chien-Jordan aquifer

$\checkmark \quad$ Cell representing Bedrock valley deposits

Confining unit

Particle path-lines -- Forward tracking from the recharge (land) surface.

Figure 18. Path-line plot representing movement through the drift and Plattville aquifer systen of recharge water derived from the infiltration of precipitation with the vertical hydraulic conductivity of model layer 4, representing the upper part of the lower drift confining unit, increased by a factor of 100 in the western part of the modeled cross section, St. Louis Park area, Minnesota (trace of section shown in figure 3). 
layer 1) to $1.3 \mathrm{ft}$ in model layer 5, representing the lower drift aquifer and lower part of the lower drift confining unit and in model layer 6, representing the Platteville aquifer and bedrock valley deposits (table 8 ).

Calculated hydraulic heads in the St. Peter aquifer (model layer 7) were as much as $6.0 \mathrm{ft}$ lower, with the mean decrease for the aquifer being $3.4 \mathrm{ft}$.

As a result of simulating a hypothetical extension of the Glenwood confining unit in columns 46 to 72 , the net horizontal boundary flow for the Platteville aquifer and bedrock valley deposits (model layer 6) decreased by about 49 percent (table 9 ). Eastern boundary outflow from model layer 6 increased by 43 percent and the amount of water leaking to the underlying St. Peter aquifer (model layer 7) decreased by about 98 percent. The water impeded from leaking downward from the drift and Platteville aquifer system (model layers 1-6) to model layer 7, representing the St. Peter aquifer was discharged by boundary outflow, predominantly through model layer 6, representing the Platteville aquifer and bedrock valley deposits. The net boundary flow for model layer 7 , representing the St. Peter aquifer, more than doubled (increased by about 104 percent, table 9 ). Eastern boundary outflow from model layer 7 was reduced by 59 percent.

\section{Summary of cross-sectional model simulation results}

The study and cross-sectional model simulations have resulted in a better understanding of (1) the extent and hydraulic properties of the hydrogeologic units comprising the drift and Platteville aquifer system, particularly the confining units, and (2) local groundwater flow through the aquifer system. The simulation results indicate that reasonable estimates of vertical hydraulic conductivities for the drift confining units, a hydraulic property spanning orders of magnitude and involving much uncertainty as to correct values, were obtained. Results of the model simulations indicate that by increasing the vertical hydraulic conductivity of a confining unit, greater downward movement of water from overlying to underlying aquifers would result. Increasing the vertical hydraulic conductivity of confining units in the drift and Platteville aquifer system (model layers 1-6) by a factor of 10 resulted in increases in net flux across the lower boundaries of adjacent aquifers ranging from about 2 percent for the middle drift aquifer (model layer 3 ) to about 24 percent for the Platteville aquifer and bedrock valley deposits (model layer 6 ). The increased vertical movement of ground water would presumably result in increased vertical movement of contaminants.
The model simulations indicate that most of the vertical movement of water downward through the drift and Platteville aquifer system occurs southeast of the plant site near the bedrock valley (figs. 15 and 16). Ground-water flow vertically downward from the unconfined drift aquifer underlying the plant site is greatly impeded by the upper drift confining unit. The model simulated that about 56 percent of the leakage of water through the upper drift confining unit (model layer 2) occurred in model columns 46 to 80 . About 48 percent of the downward leakage of water through the upper part of the lower drift confining unit (motel layer 4) also occurred in the eastern part of the cross section (columns 46 to 91 ). This is because the till and clay comprising the confining unit in this area is sandier and has a greater vertical hydraulic conductivity then in the western part. Of the water that leaks downward through the upper part of the lower drift confining unit (model layer 4 ) in the western part of the cross section (columns 1 to 45 ), about 93 percent occurs in columns 17 to 21 because of thinning of the confining unit and ircreased sand content. The model simulations indicate that the potential for the vertical movement of contaminants through the drift and Platteville aquifer system is greater southeast of the plant site than directly beneath the plant site, which is the source area of the contaminarts.

The cross-sectional model simulations done for this study indicate the presence or absence of the Glenwood confining unit affects the downward movement of water from the drift and Platteville aquifer system to the underlying St. Peter aquifer. About 99 percent of the leakage to the St. Peter aquifer (model layer 7 ) along the cross-sectional model occurs in areas where this confining unit is absent. The results of the model simulations, when combined with data presented by Hult (1984), indicate that increased vertical grcindwater flow from the drift and Platteville aquifer system to underlying bedrock aquifers through bedroc' valleys results in elevated concentrations and greater vertical movement of contaminants in areas underlain 1 :" bedrock valleys as compared to areas not unde-lain by bedrock valleys. Bedrock valleys, therefore, could be major pathways for the vertical movement of contaminants through the drift and Platteville aquifer system to the underlying bedrock aquifers.

The results of the model sensitivity analysis and the simulations of hypothetical variations of the extent of the confining units indicate that the calculated steadystate hydraulic heads are less sensitive to large changes in the hydraulic properties and the extent and continuity of confining units than are simulated ground-water flows. Simulated ground-water flow was significantly affected by these changes, especially by varyir 9 the 
areal extent of the Glenwood confining unit. Additional test drilling to locate discontinuities in confining units might be necessary to ascertain the potential for the vertical movement of contaminants through the drift and Platteville aquifer system. The cross-sectional model results indicate that field measurements of hydraulic head might not help locate discontinuities in confining units in this hydrogeologic setting.

\section{Summary and Conclusions}

The drift and Platteville aquifer system is composed of glacial drift and the underlying Platteville aquifer. Three aquifer units and two confining units have been defined within the drift underlying the area near the site of a former coal-tar distillation and wood-preserving plant in St. Louis Park, Minnesota. The aquifer units, in descending order, are the upper drift, middle drift, and lower drift aquifers. The confining units, in descending order are the upper drift and lower drift confining units.

The upper drift aquifer ranges in composition from peat to sand and gravel, with a maximum saturated thickness of $25 \mathrm{ft}$. The horizontal hydraulic conductivity of the aquifer ranges from less than 1 to about $25 \mathrm{ft} / \mathrm{d}$ in the peat areas and from about 50 to 400 $\mathrm{ft} / \mathrm{d}$ in the sand and gravel areas. The saturated thickness of the middle drift aquifer ranges from about 4 to $82 \mathrm{ft}$, but generally is 20 to $30 \mathrm{ft}$ in areas where the aquifer is both overlain and underlain by a confining unit. The composition of the middle drift aquifer varies from silty sand to medium-to-coarse sand and fine gravel, with a range in horizontal hydraulic conductivity from about 50 to $500 \mathrm{ft} / \mathrm{d}$. The lower drift aquifer consists of discontinuous sand and gravel deposits overlying Platteville Formation bedrock and has a maximum thickness of $20 \mathrm{ft}$ where it is overlain by the lower drift confining unit. The aquifer generally is present in a northwest-to-southeast trending band (about 0.3 to 1.0 miles wide) transecting the former plant site and generally is absent outside this band.

The upper drift confining unit is a discontinuous bed of lake deposits, silty to sandy clay, and till underlying the upper drift aquifer. The upper drift confining unit generally is less than $20 \mathrm{ft}$ thick, but may be as much as $62 \mathrm{ft}$ thick. The lower drift confining unit underlies the middle drift aquifer, consists of sandy to silty clay and till, and is as much as $50 \mathrm{ft}$ thick. Reported vertical hydraulic conductivities for clays and tills with varying amounts of sand range from 0.00004 to $0.2 \mathrm{ft} / \mathrm{d}$.

The drift in the study area is underlain by two subcropping bedrock aquifers, the Platteville and the St. Peter. The Platteville aquifer and underlying Glenwood confining unit are dissected by bedrock valleys in the central and southeastern parts of the study area. The valleys are filled with drift. The Platteville aquifer is as much as $29 \mathrm{ft}$ thick, with a reported transmissivity of about $9,000 \mathrm{ft}^{\prime} / \mathrm{d}$. The Glenwood confining unit has a maximum thickness of about $15 \mathrm{ft}$ and a vertical hydraulic conductivity estimated to be about $9 \times 10^{\prime \prime}$ $\mathrm{ft} / \mathrm{d}$.

Water in the drift and Platteville aquifer system in the study area generally flows from the west to east under a hydraulic gradient of about $10 \mathrm{ft} / \mathrm{mi}$. Southeast of the plant site water in the drift and Platteville aquifer system generally flows from the northwest to the southeast. Sources of recharge to the drift and Platteville aquifer system are infiltration of precipitation at the land surface, and ground-water inflow to the drift and Platteville aquifers from the west. Discharge from the drift and Platteville aquifer system is by ground-water outflow from the drift and Platteville aquifers to the east. ground-water discharge to surface-water bodies, ground-water evapotranspiration, and ground-water withdrawals by wells. Water also discharges from the drift and Platteville aquifer system by the downward leakage of water to the underlying St. Peter aquifer.

Ground-water flow predominantly is horizont $\varepsilon^{\prime}$ in aquifers and predominantly vertical in confining units. The confining units control the vertical movemert of water through the drift and Platteville aquifer system. The amount of leakage depends on the vertical hydraulic conductivity, the thickness of the confining unit, and the difference in hydraulic heads between the adjacent aquifers. Discontinuities in the confining units greatly affect patterns of flow in the drift and Platteville aquifer system because the vertical hydraulic conductivity of the material filling the discontinuity generally is much greater than that of the confining unit.

A numerical cross-sectional ground-water-flow computer model was constructed and calibrated for steady-state conditions. The model was used to tost concepts of flow of ground water through the drift and Platteville aquifer system in the study area, particularly the influence of confining units and bedrock valleys on vertical flow. The model contains eight layers that represent, in descending order: (1) the upper drif ${ }^{+}$ aquifer, (2) the upper drift confining unit, (3) the middle drift aquifer, (4) the upper part of the lower drift confining unit, (5) the lower drift aquifer and laterally adjacent lower part of the lower drift confining unit, (6) the Platteville aquifer and bedrock valley deposit . (7) the St. Peter aquifer, and (8) the Prairie du Chien-Jordan aquifer. The Glenwood confining unit and basal St. Peter confining unit are represented in the model by leakage terms that incorporate the thickness and vertical 
hydraulic conductivity of the unit in each model cell. The simulated recharge to the drift and Platteville aquifer system by precipitation represents the net difference between precipitation and evapotranspiration losses occurring both in the unsaturated zone and at the water table. Measured hydraulic heads in the drift and Platteville aquifer system during December 1987 were used to define boundary conditions and calibrate the model.

The model was calibrated by varying the values of horizontal and vertical hydraulic conductivities of the hydrogeologic units represented in the model and simulated recharge to the drift and Platteville aquifer system until calculated hydraulic heads acceptably matched measured water levels in wells along the cross section. The best-fit calculated hydraulic heads in the drift and Platteville aquifer system generally were within $0.2 \mathrm{ft}$ of measured water levels in wells along the cross section. The mean difference between calculated and measured hydraulic heads, calculated as the sum of the absolute values of the differences divided by the number of wells, was $0.18 \mathrm{ft}$. The best-fit calibrated value for recharge to the drift and Platteville aquifer system was $6.0 \mathrm{in.} / \mathrm{yr}$.

The water budget calculated using the cross-sectional model shows that recharge to the uppermost model layers from the infiltration of precipitation accounts for about 41 percent of the total sources of water and boundary inflow from the west accounts for about 59 percent. Simulated boundary inflow to the middle drift aquifer accounts for nearly 32 percent of the total sources of water. The only simulated discharges are boundary outflows from the eastern end of the crosssectional model. About 70 percent of the simulated boundary outflow discharges from the Platteville aquifer and bedrock valley deposits and the St. Peter aquifer. About 21 percent discharges from the middle drift aquifer and about 9 percent discharges from the Prairie du Chien-Jordan aquifer.

The water entering the simulated drift and Platteville aquifer system (excluding the underlying St. Peter and Prairie du Chien-Jordan aquifers) discharges from the system by (1) leakage to the underlying St. Peter aquifer (about 40 percent), (2) boundary outflow from the Platteville aquifer and bedrock valley deposits (about 36 percent), and (3) boundary outflow from the middle drift aquifer (about 24 percent). The presence or absence of the Glenwood confining unit strongly influences the amount and pattern of leakage from the drift and Platteville aquifer system to the underlying St. Peter aquifer. About 99 percent of the total simulated leakage to the St. Peter aquifer flows through the areas where the Glenwood confining unit is absent or discontir'ıous.

A particle-tracking post-processing program was used to compute ground-water-flow path lines based on output from the cross-sectional model. Plots $\mathrm{c}^{f}$ the computed path lines indicate that (1) most of the recharge to the simulated drift and Platteville aquifer system at the land surface moves horizontally in the western part of the cross section and discharges from the simulated drift and Platteville aquifer system ty boundary outflow and leakage to the St. Peter aquifer in the eastern part, and (2) much of the water der ved from simulated boundary inflow discharges by simulated leakage to the St. Peter aquifer prior to reachirg a bedrock valley in the eastern part of the cross section.

A model-sensitivity analysis indicated that calculated hydraulic heads in the drift and Platteville aquifer system were most sensitive to variations in simulated values representing (1) the horizontal hydrauli? conductivities of the middle drift aquifer, (2) the transmissivities of the Platteville and St. Peter aquifers, (3) the vertical hydraulic conductivities of the lower drift confining unit, (4) the vertical hydraulic conductivity of the drift material filling the bedrock valley where the Platteville aquifer and Glenwood confining unit are absent, (5) the vertical hydraulic conductivity of the basal St. Peter confining unit, and (6) recharge. The calculated steady-state hydraulic heads varied by $0.3 \mathrm{ft}$ or less in most cases in response to large changes in the hydraulic properties representirg the hydrogeologic units, whereas calculated grourd-water flow in the drift and Platteville aquifer system was significantly affected.

The calibrated steady-state cross-sectional model was used to investigate the effects on calculated hydraulic heads and simulated ground-water flow in the drift and Platteville aquifer system of hypothetical changes of the simulated hydraulic properties of confining units and the areal extent of the Glenwood confining unit. The hypothetical changes simulated included (1) ir reasing the vertical hydraulic conductivity of the upper part of the lower drift confining unit by a factor of 10 ? in the western part (model columns 1 to 60 ) of the cross section, (2) representing the Glenwood confining unit as continuous in the area west of the bedrock valley (model columns 46 to 62 ), (3) representing the Glenwood confining unit as continuous across the bedrock valley (model columns 63 to 72), and (4) representing the Glenwood confining unit as continuous across the bedrock valley and the area west of the bedrock valley (model columns 46 to 72 ), or along the entire cross section. Increasing the simulated vertical hyd aulic 
conductivity of the upper part of the lower drift confining unit in the western part of the cross section resulted in: (1) mean changes in calculated hydraulic heads ranging from $-0.8 \mathrm{ft}$ in the upper drift aquifer to $+0.6 \mathrm{ft}$ in the lower drift aquifer and lower part of the lower drift confining unit, (2) increased simulated leakage to the St. Peter aquifer in the western part of the cross section, and (3) decreased simulated leakage to the St. Peter aquifer through the bedrock valley in the eastern part of the cross section.

A simulated hypothetical extension of the Glenwood confining unit across the bedrock valley and the area west of the bedrock valley (model columns 46 to 72 ), or along the entire cross section resulted in rises in calculated hydraulic heads in the drift and Platteville aquifer system. Mean rises ranged from $0.7 \mathrm{ft}$ in the upper drift aquifer to $1.3 \mathrm{ft}$ in the lower drift aquifer and lower part of the lower drift confining unit and the Platteville aquifer and bedrock valley deposits. There was a 98-percent reduction in the simulated amount of water leaking from the Platteville aquifer and bedrock valley deposits to the underlying St. Peter aquifer. The ground water impeded from leaking downward to the St. Peter aquifer in the simulation was discharged by boundary outflow, predominantly through the Platteville aquifer.

The cross-sectional model simulations indicate that the potential for the vertical movement of contaminants through the drift and Platteville aquifer system is greater southeast of the plant site near a bedrock valley than it is underlying the plant site. Increased vertical groundwater flow from the drift and Platteville aquifer system through the bedrock valleys to underlying bedrock aquifers could result in both elevated concentrations and greater vertical movement of contaminants near the valleys. Additional test drilling to locate discontinuities in confining units might be necessary to ascertain the potential for the vertical movement of contaminants through the drift and Platteville aquifer system. Results of the cross-sectional model simulations indicate that field measurements of hydraulic head might not help locate discontinuities in confining units in the hydrogeologic setting near the plant site.

\section{References Cited}

Barr Engineering Co., 1976, Soil and ground-water investigation, coal-tar distillation and woodpreserving site, St. Louis Park, Minnesota: Minneapolis, Minnesota, $152 \mathrm{p}$.
1977, Soil and ground-water investigation, former coal-tar distillation and wood-preserving facility, St. Louis Park, Minnesota: Minneapolis, Minnesota, $191 \mathrm{p}$.

Environmental Research and Technology, 1983, Recommended plan for a comprehensive solution of the polynuclear aromatic hydrocarbon contamination problem in the St. Louis Park area: Document P-B690-161, Concord, Massachusetts, $247 \mathrm{p}$.

Freeze, R.A., and Cherry, J.A.. 1979, Groundwator: Englewood Cliffs, N.J., Prentice Hall, 604 r

Guswa. J.H., Siegel, D.I., and Gillies, D.G., 1982, Preliminary evaluation of the ground-water-flow system in the Twin Cities Metropolitan Area, Minnesota: U.S. Geological Survey WaterResources Investigations 82-44.

Helgesen, J.O., and Lindholm, G.F., 1977, Geology and water-supply potential of the Anoka Sand-Plain aquifer, Minnesota: Minnesota Department of Natural Resources, Technical Paper No. 6.17 p.

Hickok, E.A., and Associates, 1969, Report to the Minnehaha Watershed District: Minneapolis, Minnesota, $20 \mathrm{p}$.

Hult, M.F., 1984, Assessment of ground-water contamination by coal-tar derivatives, St. Louis Park Area, Minnesota: U.S. Geological Survey Open-File Report 84-867, 56 p.

Hult, M.F., and Schoenberg, M.E., 1984, Preliminary evaluation of ground-water contamination by:r coaltar derivatives, St. Louis Park area, Minnesota: U.S. Geological Survey Water-Supply Paper 2211, $53 \mathrm{p}$.

Koch, N.C., 1980, Appraisal of the water resourcss of the Big Sioux aquifer, Brookings, Deuel, and Hanlin Counties, South Dakota: U.S. Geological Survey Water-Resources Investigations Report 80$100,46 \mathrm{p}$.

Liesch, B.A., 1973, Ground-water investigation for the Minnesota Highway Department at the Minrehaha Park Tunnel: State Project No. 2724-48, Minneapolis, Minnesota, $131 \mathrm{p}$.

Lindgren, R.J., 1990, Simulation of ground-water flow in the Prairie du Chien-Jordan and overlying aquifers near the Mississippi River, Fridley, Minnesota: U.S. Geological Survey WaterResources Investigations Report 90-4165, 152 p. 
Lorenz, D.L., and Stark, J.R., 1990, Simulation of ground-water flow in the St. Peter aquifer in an area contaminated by coal-tar derivatives, St. Louis Park, Minnesota: U.S. Geological Survey Water-Resources Investigations Report 90-4150, $37 \mathrm{p}$.

McDonald, M.G., and Harbaugh, A.W., 1988, A modular three-dimensional finite-difference ground-water flow model: U.S. Geological Survey Techniques of Water-Resources Investigations, Book 6, Chapter Al, $586 \mathrm{p}$.

Minnesota Department of Health, 1938, Report on investigation of disposal of wastes at the Republic Creosoting Company, St. Louis Park, Minnesota: Minneapolis, Minnesota, $10 \mathrm{p}$.

1974. Report on investigation of phenol problem in private and municipal wells in St. Louis Park, Minnesota, Hennepin County: Minneapolis, Minnesota, $24 \mathrm{p}$.

1977, Assessment of possible human health effects resulting from contamination of the former Republic Creosote site: Minneapolis, Minnesota, $72 \mathrm{p}$.

1978. Health implications of polynuclear aromatic hydrocarbons in St. Louis Park drinking water: Minneapolis, Minnesota, 26 p.

Morris, D.A., and Johnson, A.I., 1967, Summary of hydrologic and physical properties of rock and soil materials, as analyzed by the hydrologic laboratory of the U.S. Geological Survey 1948-60: U.S. Geological Survey Water-Supply Paper 1839-D, $42 \mathrm{p}$.

National Biocentric, Inc., 1976a, Soil boring and chemical analysis of the northern part of the Oak Park Village: Consultant's report to the city of St. Louis Park. St. Paul, Minnesota, 54 p.

1976b, A quantitative physical/chemical analysis of the northern portion of the former Republic Creosote site: Consultant's report to the city of St. Louis Park, St. Paul, Minnesota, 73 p.

Norvitch, R.F., Ross, T.G., and Brietkrietz, Alex, 1974, Water-resources outlook for the Twin Cities Metropolitan Area: Metropolitan Council of the Twin Cities, $219 \mathrm{p}$.

Olsen, B.M., and Bloomgren, B.A., 1989, Bedrock Geology in Geologic Atlas Hennepin County, Minnesota, County Atlas Series, Atlas C-4, Scale 1:100,000, 9 plates, Minnesota Geological Survey, St. Paul, Minnesota.
Olson, B.M., Bloomgren, B.A., and Hoagberg, R.K., 1974, The geology of the St. Louis Park area: A review: Minnesota Geological Survey report to the Minnesota Department of Health, $20 \mathrm{p}$.

Pollock, D.W., 1989, Documentation of comp'tter programs to compute and display pathlines using results from the U.S. Geological Survey modular three-dimensional finite-difference ground-water flow model: U.S. Geological Survey Opan-File Report 89-381, $188 \mathrm{p}$.

Schoenberg, M.E., 1984, Water levels and water-level changes in the Prairie du Chien-Jordan and Mount Simon-Hinckley aquifers, Twin Cities Metropolitan Area, Minnesota, 1971-80: U.S. Geological Survey Water-Resources Investigations Report 83-4237, 23 p. 1990, Effects of present and projected groundwater withdrawals on the Twin Cities aquifer system, Minnesota: U.S. Geological Survey Water-Resources Investigations Report @n-4001, $165 \mathrm{p}$.

Stark, J.R., and Hult, M.F., 1985, Ground-water flow in the Prairie du Chien-Jordan aquifer related to contamination by coal-tar derivatives, St. Louis Park, Minnesota: U.S. Geological Survey WaterResources Investigations Report 85-4087, 57 p.

Sunde, G.M., 1974, Hydrogeologic study of th 9 Republic Creosote site: Consultant's report to the city of St. Louis Park, Bloomington, Minnesota, 42 p.

Winter, T.C., and Pfannkuch, H.O., 1976, Hydrogeology of a drift-filled bedrock valley near Lino Lakes, Anoka County, Minnesota: U.S. Geological Survey Journal of Research. v. 4, no. 3 , p. 267-276. 
SUPPLEMENTAL INFORMATION SECTION 


\section{Calculation of Vertical Leakance Terms}

Leakage of water between model layers is dependent on the thicknesses and vertical hydraulic conductivities of adjacent layers and the hydraulic head difference between adjacent layers. Vertical conductance terms are calculated within the model using data from an input array which incorporates both thickness and vertical hydraulic conductivity into a single term, and using horizontal areas calculated from cell dimensions. The input array contains values of vertical hydraulic conductivity divided by thickness, termed the vertical leakance, for each cell in a model layer. Each value of vertical leakance is for the interval between a layer and the layer below it: therefore, vertical leakance is not specified for the lowermost layer in the model. The expression for vertical leakance for the case in which two adjacent model layers are used to represent two vertically adjacent hydrogeologic units is:

$$
\text { Vcont }_{i, j, k+\frac{1}{2}}=\frac{1}{\frac{\left(\frac{\Delta v_{k}}{2}\right)}{K_{Z i, j, k}}+\frac{\left(\frac{\Delta v_{k}+1}{2}\right)}{K_{Z i, j, k+1}}}
$$

where $V$ cont $\mathrm{i}_{\mathrm{i}, \mathrm{j}, \mathrm{k}+1 / 2}$ is the vertical leakance term for leakage between model layers $\mathrm{k}$ and $\mathrm{k}+1$;

$\Delta v_{k}$ is the thickness of model layer $k$;

$\Delta \mathrm{v}_{\mathrm{k}+1}$ is the thickness of model layer $\mathrm{k}+1$;

$\mathrm{K}_{\mathrm{Zi}, \mathrm{j} . \mathrm{k}}$ is the vertical hydraulic conductivity of the upper layer in cell $\mathrm{i}, \mathrm{j}, \mathrm{k}$; and

$\mathrm{K}_{\mathrm{Zi} . \mathrm{j} . \mathrm{k}+1}$ is the vertical hydraulic conductivity of the lower layer in cell $\mathrm{i}, \mathrm{j}, \mathrm{k}+1$.

The above relation was used to calculate vertical leakance terms for each layer and cell in the model, except for columns 1 to 62 and 73 to 91 in model layer 6 , representing the Platteville aquifer, model layer 7 . representing the St. Peter aquifer, and model layer 8 , representing the Prairie du Chien-Jordan aquifer (the lowermost model layer).

The Glenwood confining unit, which underlies the Platteville aquifer, and the basal St. Peter confining unit, which underlies the St. Peter aquifer, are not represented as layers in the model. Ground-water flow in these confining units is predominantly vertical, with no significant horizontal component of flow. The assumption is made that these confining units make no measurable contribution to the horizontal conductance of the overlying and underlying layers. In each case, the confining unit is treated as the vertical conductance between the overlying and underlying aquifers. This formulation for the treatment of confining unit: is frequently referred to as the "quasi-three-dime nsional" approach (McDonald and Harbaugh, 1988). T"e expression for vertical leakance in this case, in which a confining unit separates two aquifers and is no $^{+}$ represented as a layer in the model, reduces to:

$$
\text { Vcont }_{\mathrm{i}, \mathrm{j}, \mathrm{k}+\mathrm{l} / 2}=\mathrm{K}_{\mathrm{zc}} / \Delta \mathrm{z}_{\mathrm{c}}
$$

where $V$ cont $i_{i, j, k+1 / 2}$ is the vertical leakance term for leakage between model layers $k$ and $k+1$ (aquifers overlying and underlying the confining unit);

$\mathrm{K}_{\mathrm{zc}}$ is the vertical hydraulic conductivity of the confining unit; and

$\Delta z_{c}$ is the thickness of the confining unit, as ${ }^{\prime}$ ming that the vertical hydraulic conductivity of the confining unit is much smaller than the vertical hydraulic. conductivities of the aquifers. The above relat 'n was used to calculate vertical leakance terms for columns 1 to 62 and 73 to 91 in model layer 6 , representing the Platteville aquifer, and model layer 7 , representing the St. Peter aquifer.

The thicknesses of each model layer by model cell are given in feet: 


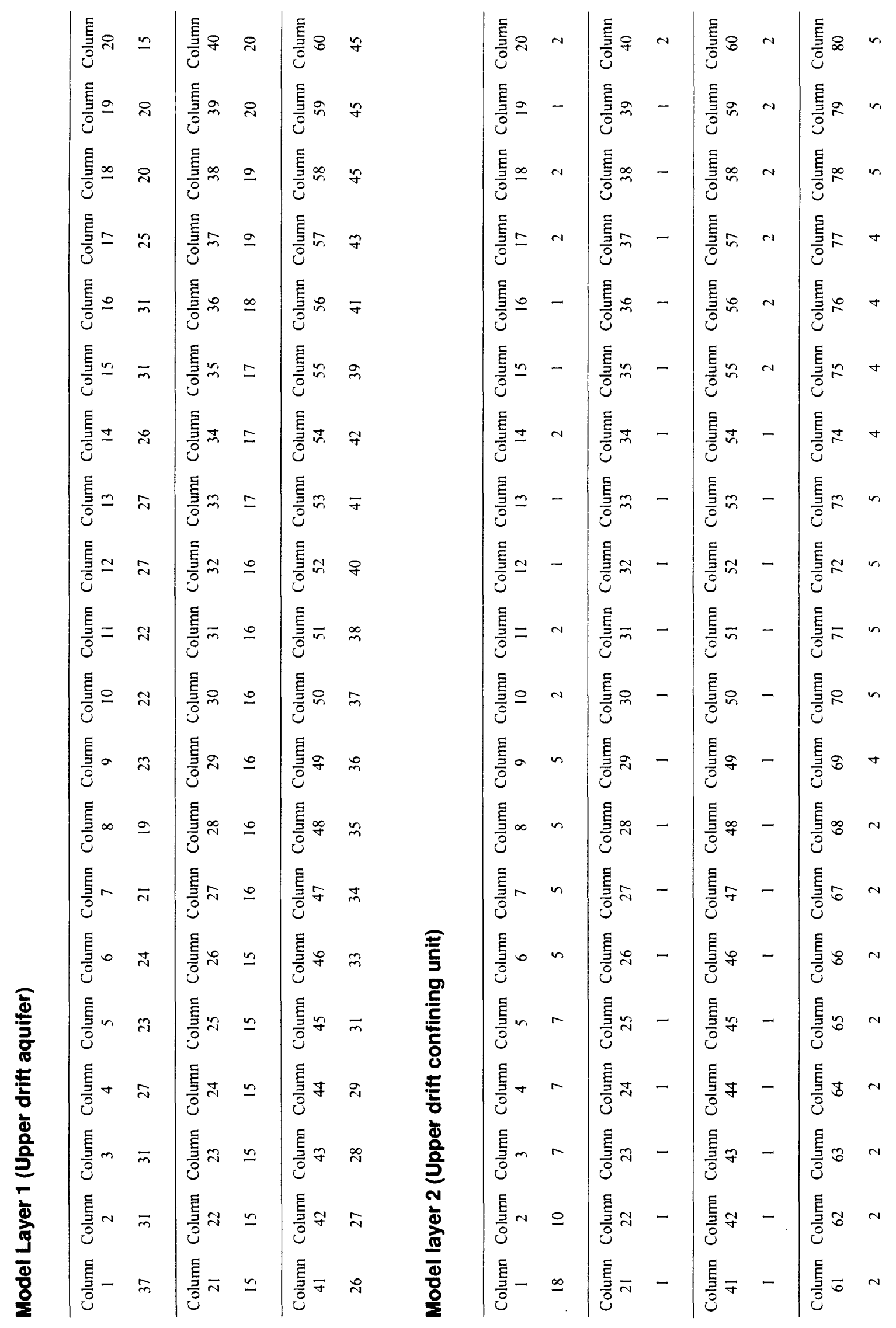

57 


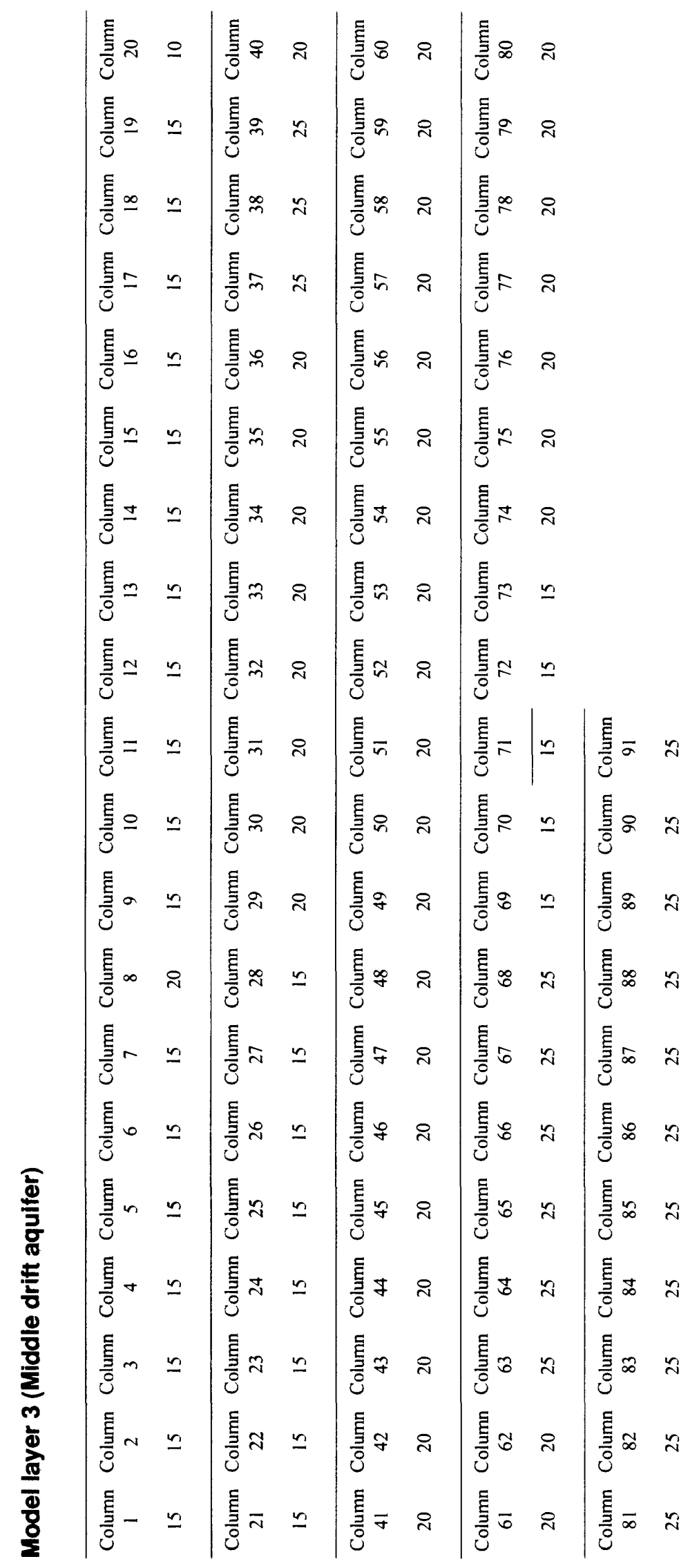

58 


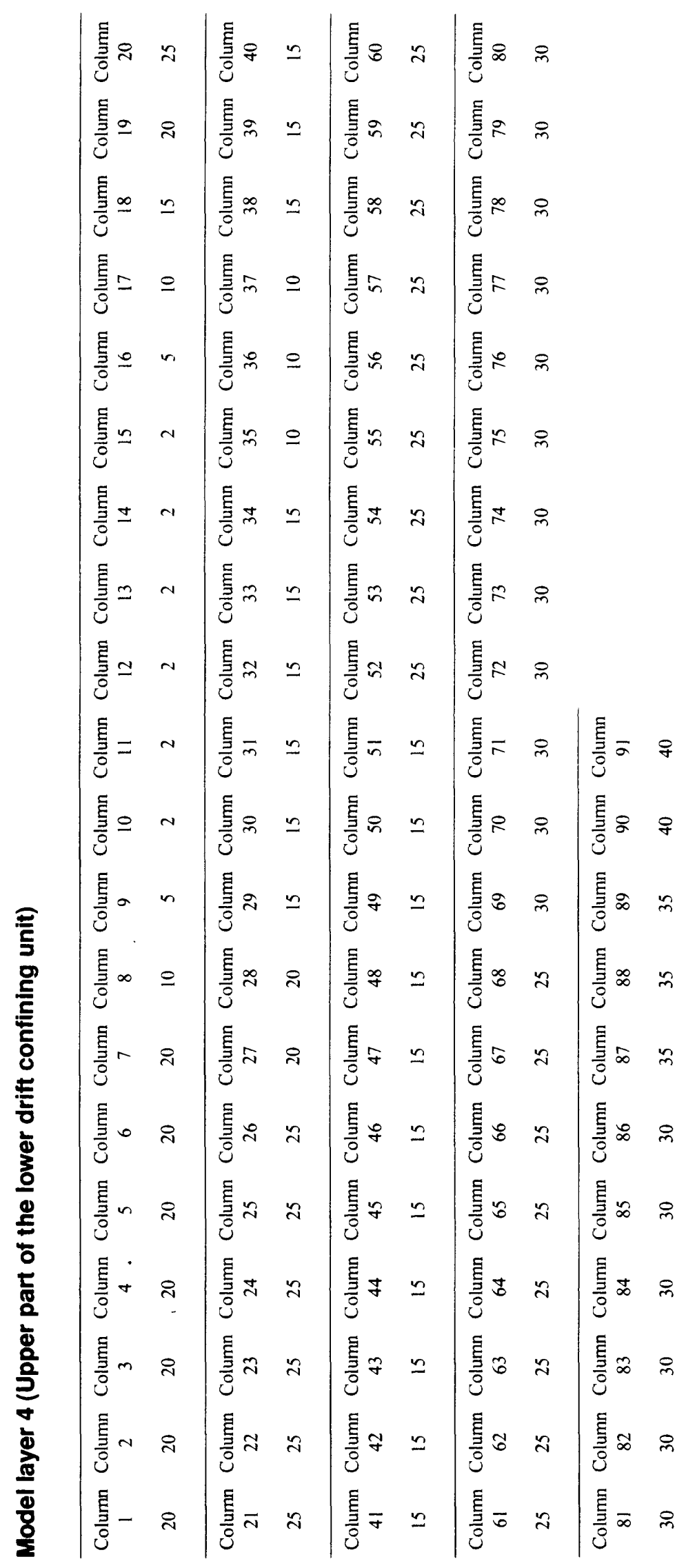

59 


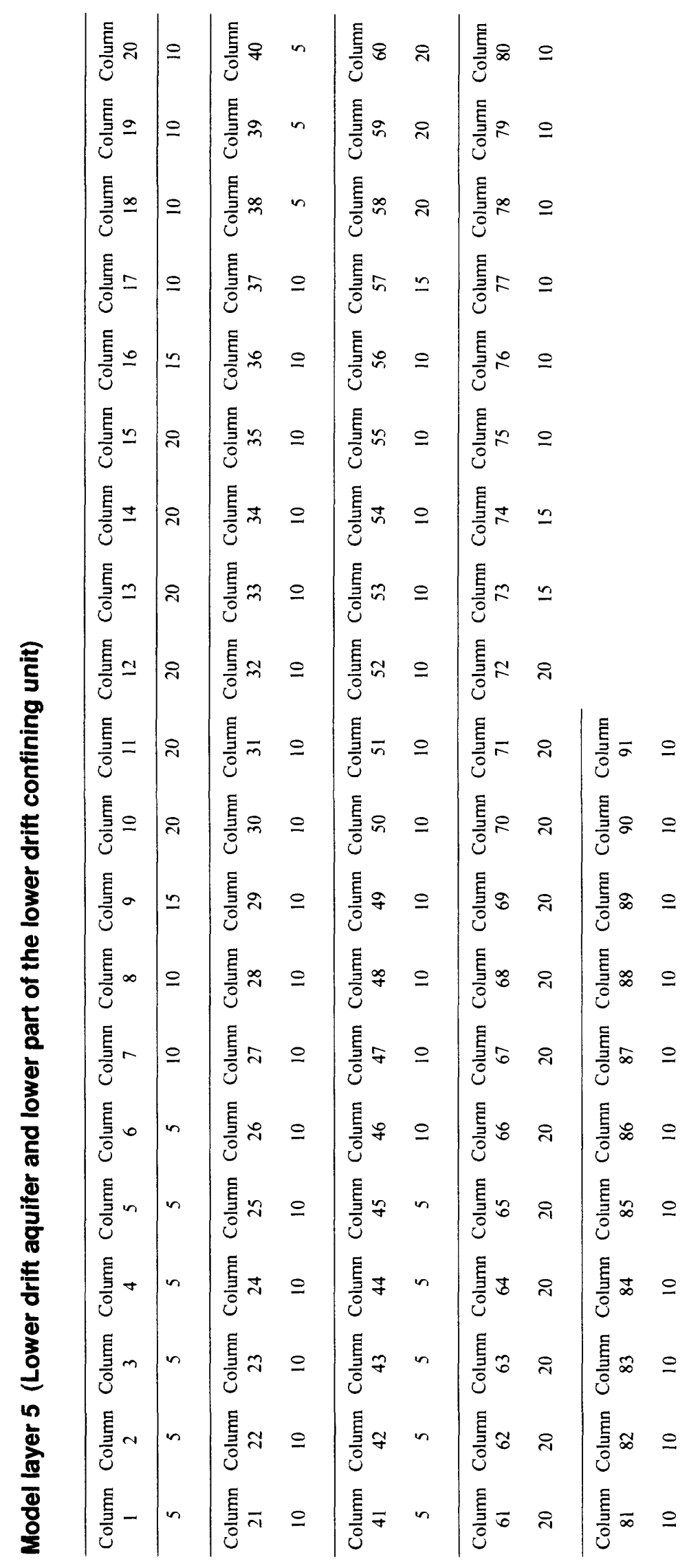

60 


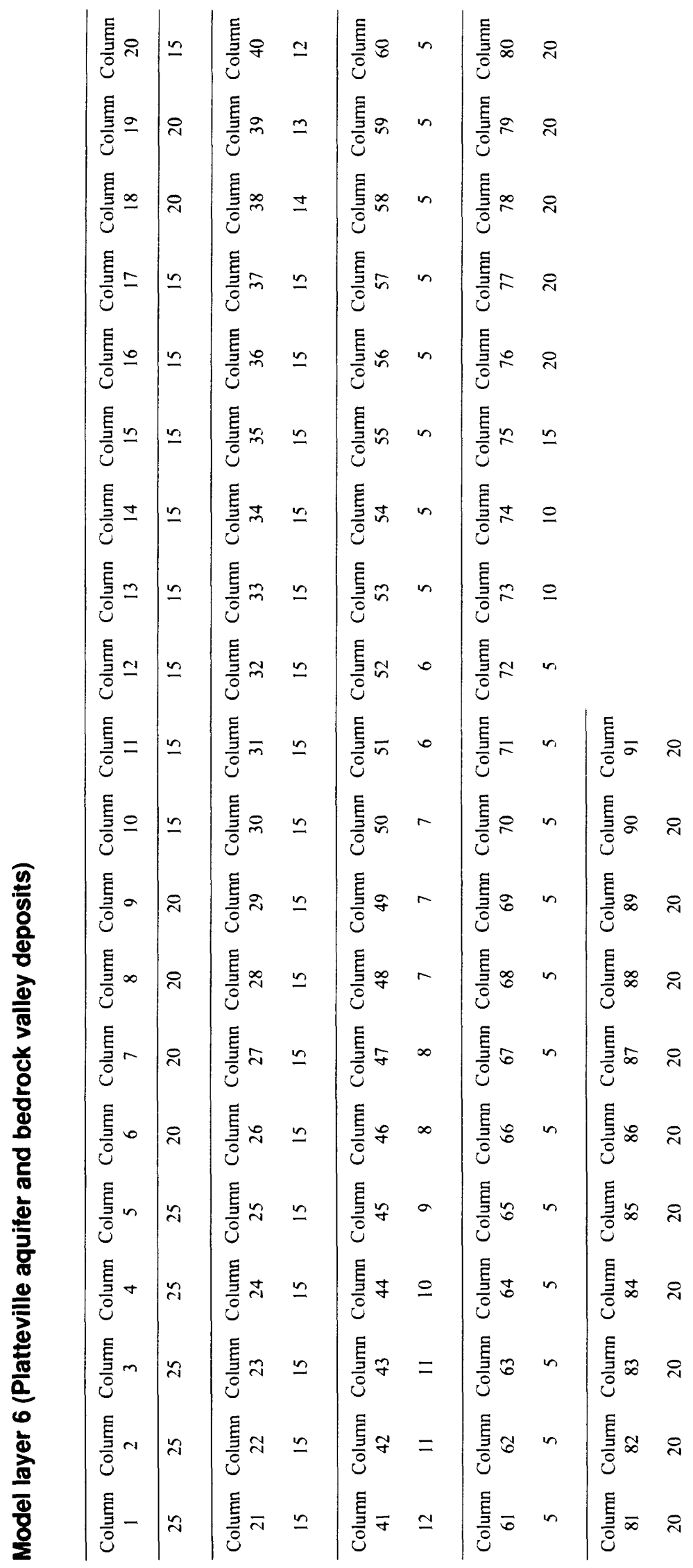

61 


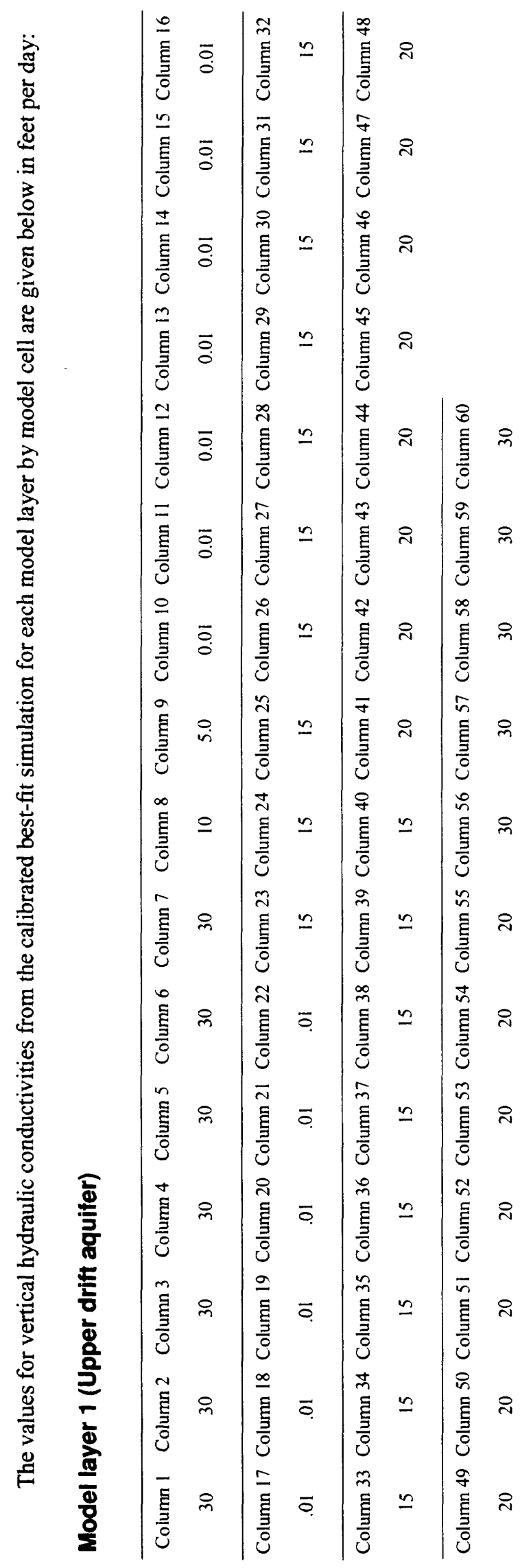




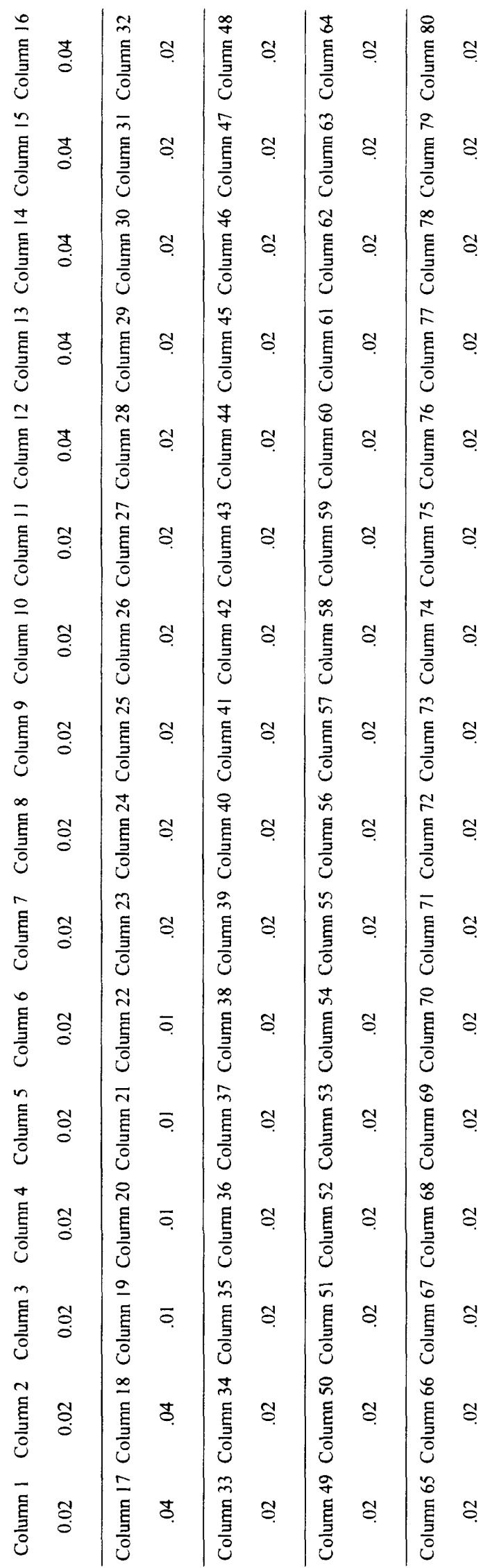




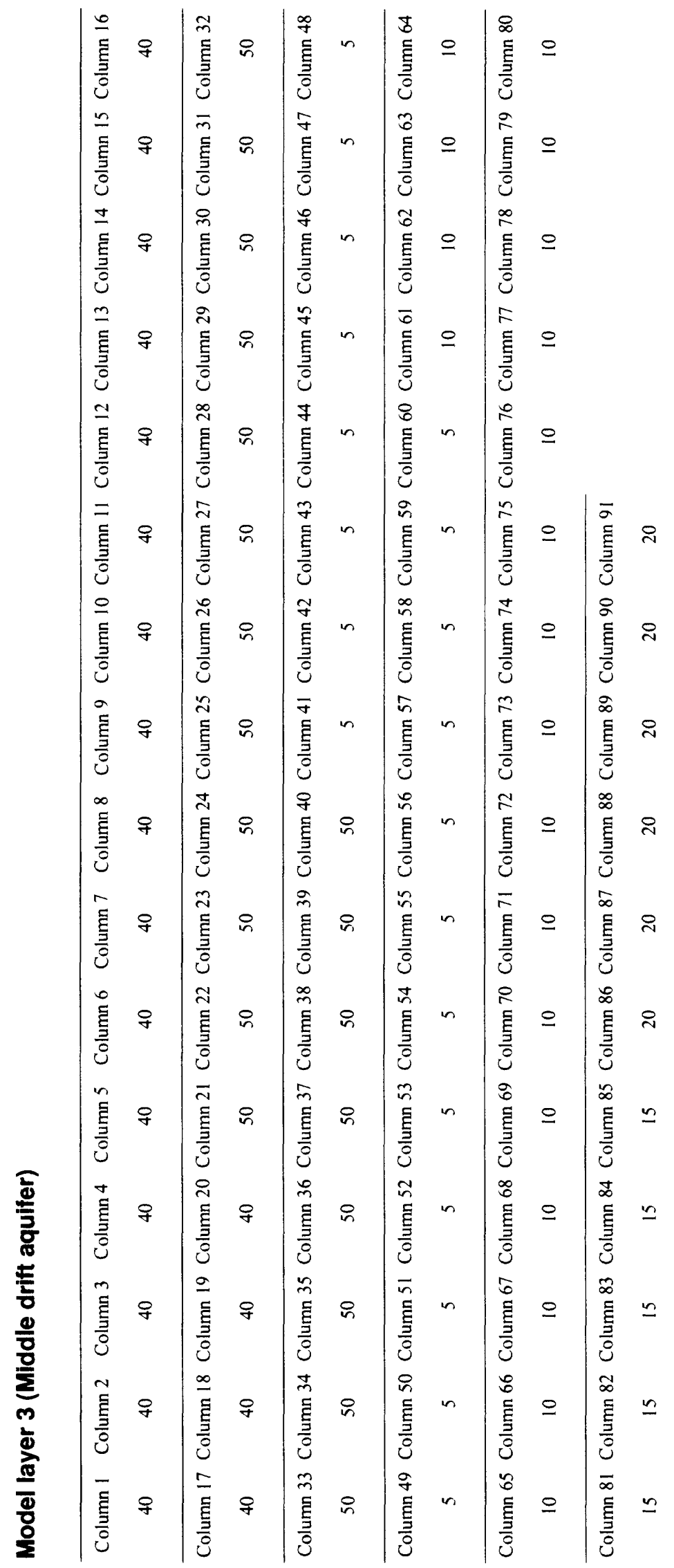




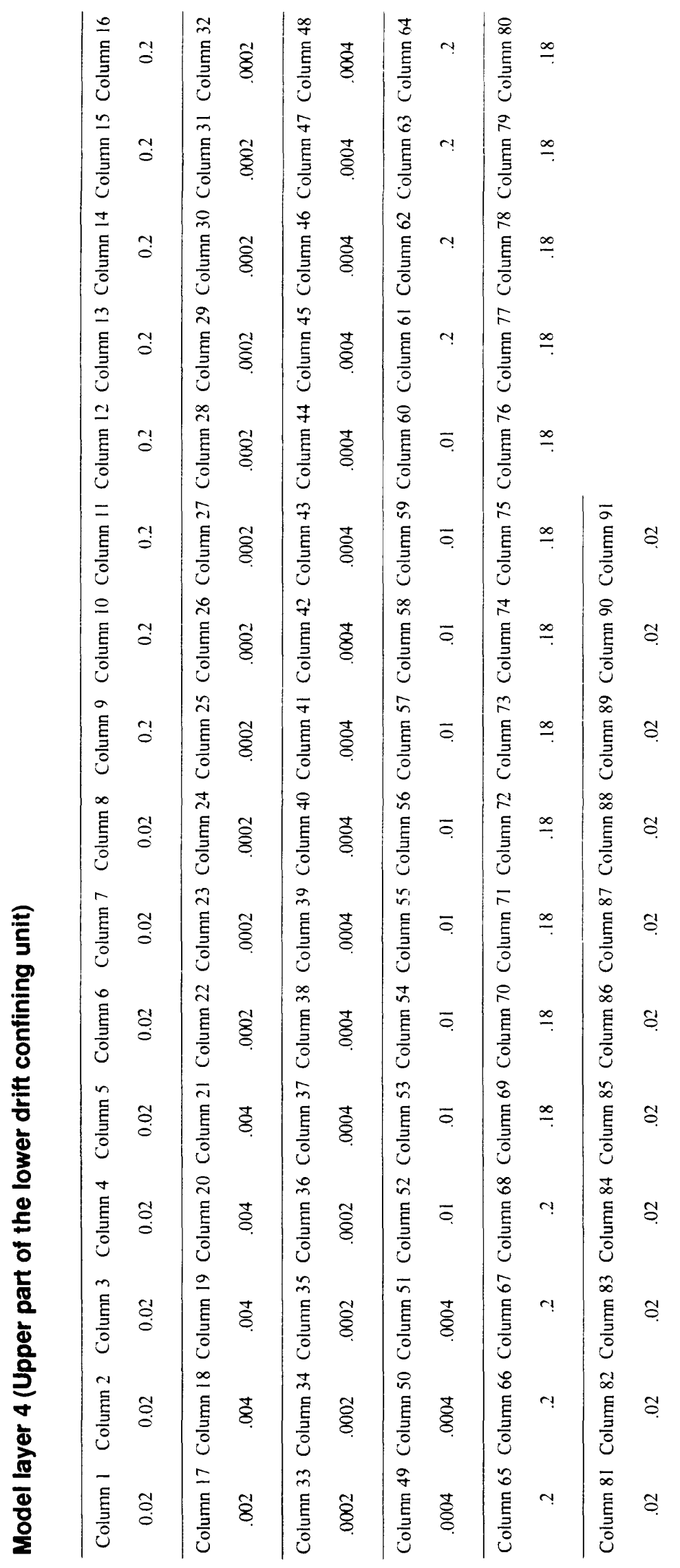




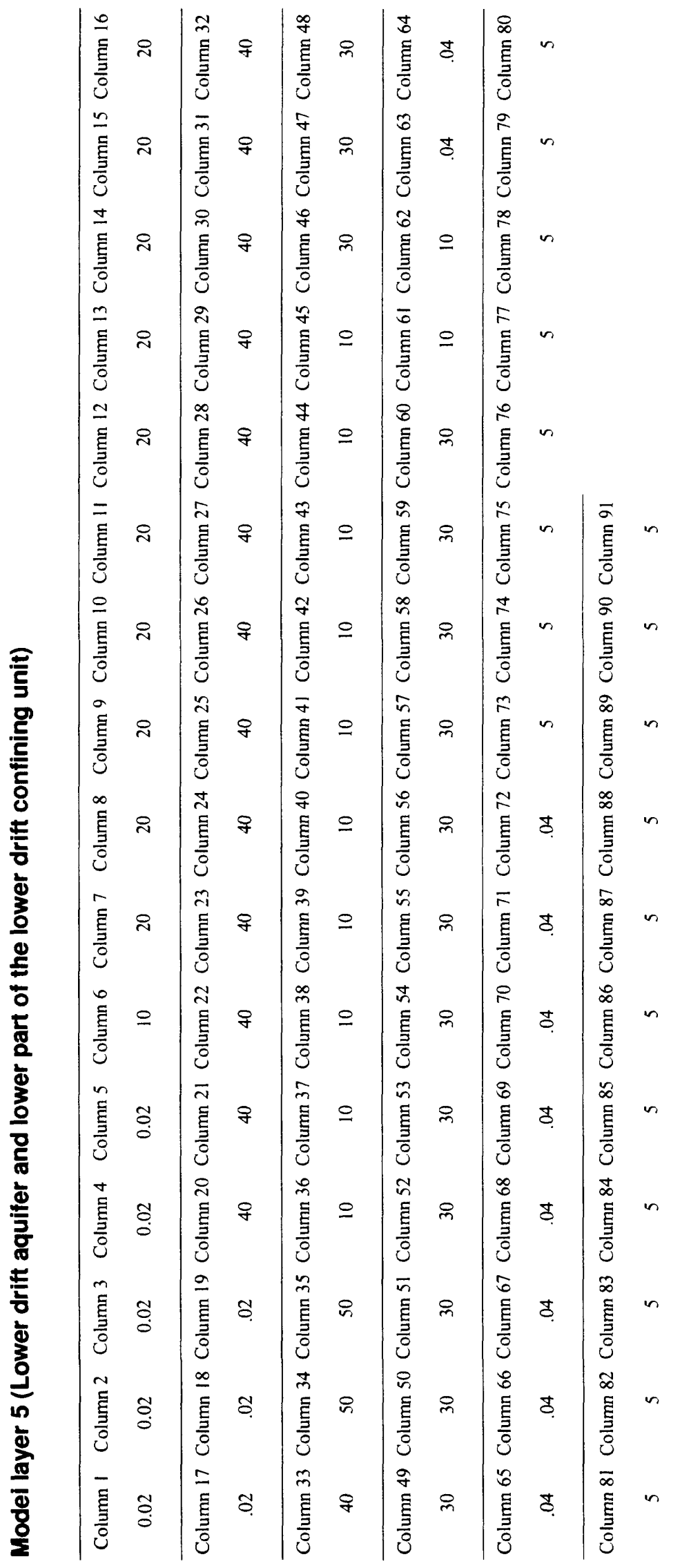




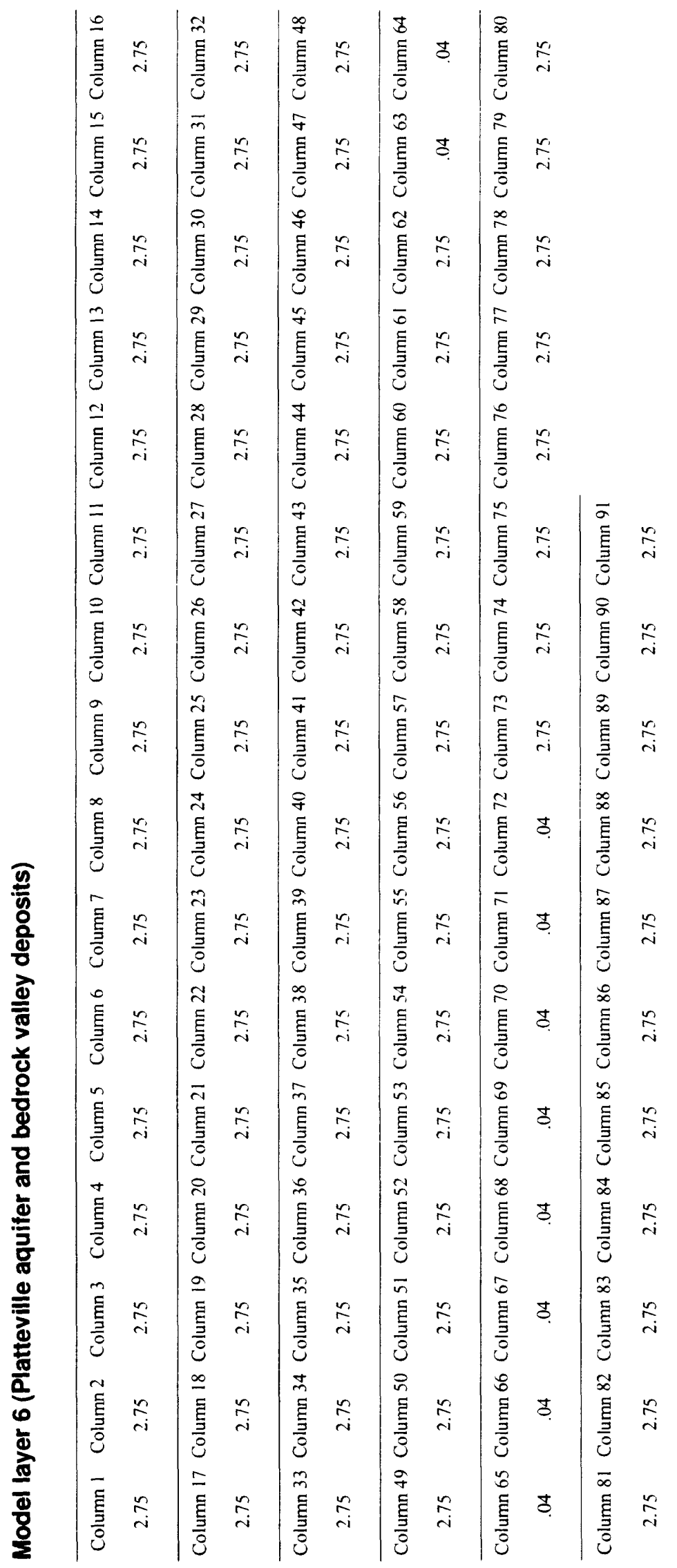




\section{Model Input Data Used for \\ Calibrated Steady-State Cross-Sectional Model}

Listings 1 to 5 contain values for a particular modular-model package as defined by McDonald and Harbaugh (1988). Listing 6 contains values for the main data file required to compute path lines as defined by Pollock (1989).

Listing 1. Input values for the BASIC package of the MODULAR program.

2. Input values for the BCF package of the MODULAR program.

3. Input values for the RECHARGE package of the MODULAR program.

4. Input values for SSOR package of the MODULAR program.

5. Input values for the Output Control Option of the BASIC package of the MODULAR program.

6. Input values for the main data file of the particle-tracking post-processing program. 


\section{Listing 1. Input values for the BASIC package of the MODULAR program}

\section{ST. LOUIS PARK CROSS-SECTION MODEL STEADY STATE 8-LAYERS}

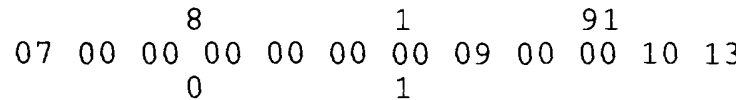

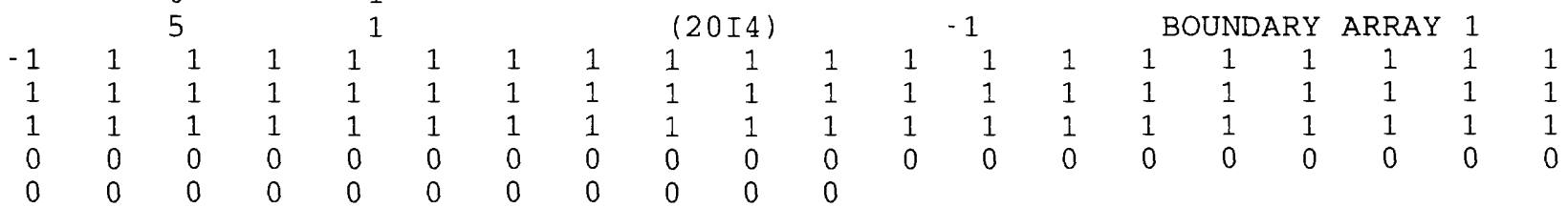

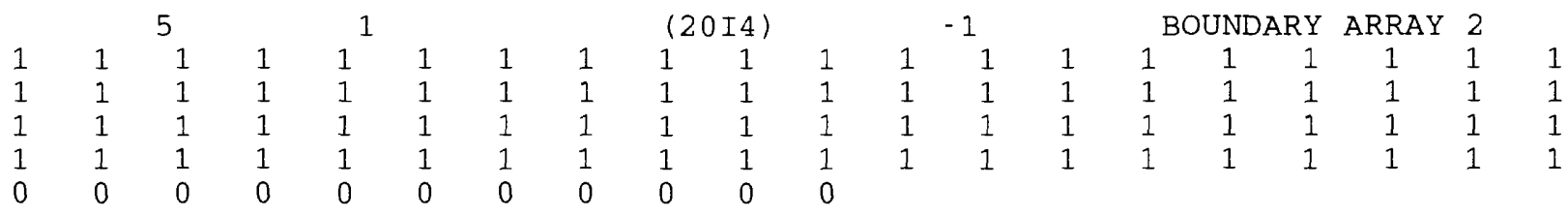

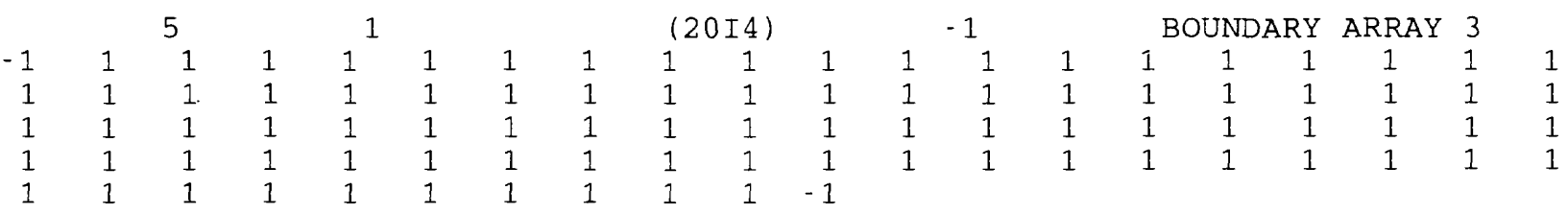

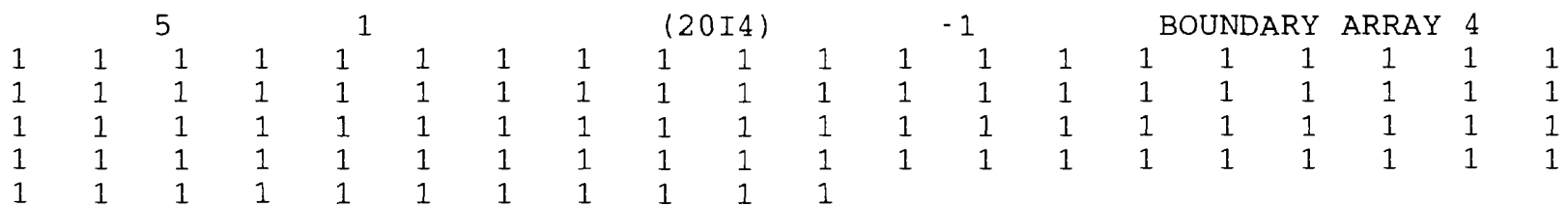

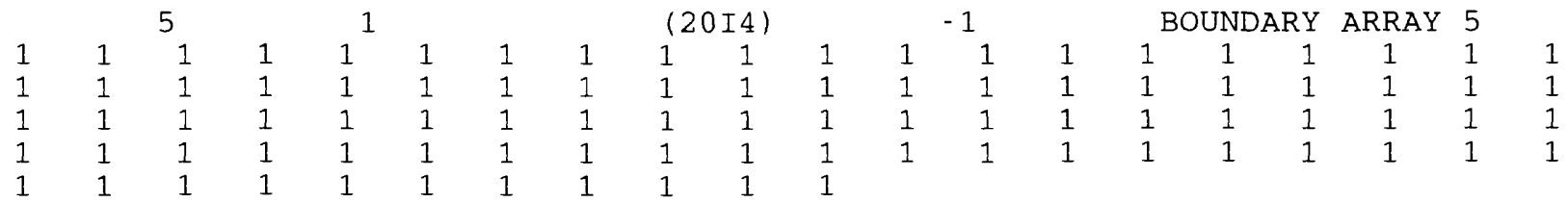

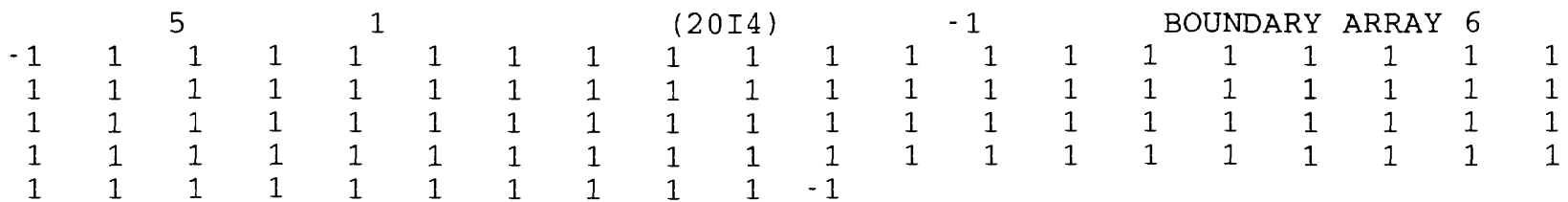

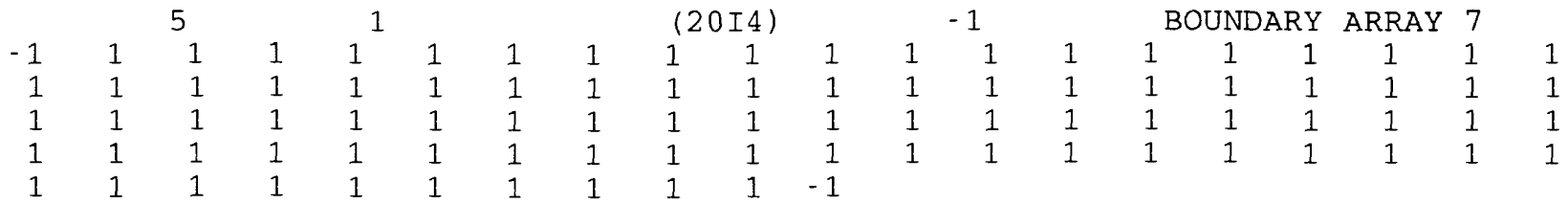

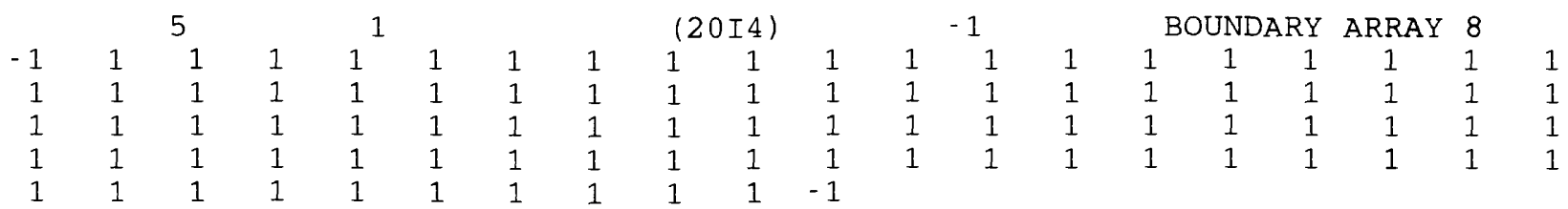




\section{Listing 1. Input values for the BASIC package of the MODULAR program--Continued}

\section{9.}
5
1.0
(16F5.1)
$-1$
START HEAD 1

890.0890 .0980 .0890 .0890 .0890 .0890 .0890 .0890 .0890 .0890 .0890 .0890 .0890 .0890 .0890 .0 890.0890 .0890 .0890 .0890 .0890 .0890 .0890 .0890 .0890 .0890 .0891 .0891 .0891 .0891 .0891 .0 892.0892 .0893 .0894 .0894 .0895 .0895 .0895 .0896 .0897 .0898 .0900 .0900 .0900 .0900 .0900 .0 900.0900 .0900 .0900 .0900 .0900 .0900 .0900 .0900 .0900 .0900 .0900 .0900 .0900 .0900 .0900 .0 900.0900 .0900 .0900 .0900 .0900 .0900 .0900 .0900 .0900 .0900 .0900 .0900 .0900 .0900 .0900 .0 900.0900 .0900 .0900 .0900 .0900 .0900 .0900 .0900 .0900 .0900 .0
5
1.0
$(16 \mathrm{~F} 5.1)$
$-1$
START HEAD 2

888.8888 .0888 .0888 .0888 .0888 .0888 .0888 .0888 .0888 .0888 .0888 .0888 .0888 .0888 .0888 .0 888.0888 .0888 .0888 .0888 .0888 .0888 .0888 .0888 .0888 .0888 .0888 .0888 .0888 .0888 .0888 .0 885.0885 .0885 .0885 .0885 .0885 .0885 .0885 .0885 .0885 .0885 .0885 .0885 .0885 .0885 .0885 .0 880.0880 .0880 .0880 .0880 .0880 .0880 .0880 .0880 .0880 .0880 .0880 .0880 .0880 .0880 .0880 .0 875.0875 .0875 .0875 .0875 .0875 .0875 .0875 .0875 .0875 .0875 .0875 .0875 .0875 .0875 .0875 .0 872.5872 .5872 .5872 .5872 .5872 .5872 .5872 .5872 .5872 .5870 .9

\section{$5 \quad 1.0 \quad(16 F 5.1) \quad-1 \quad$ START HEAD 3}

888.8888 .0888 .0888 .0888 .0888 .0888 .0888 .0888 .0888 .0888 .0888 .0888 .0888 .0888 .0888 .0 888.0888 .0888 .0888 .0888 .0888 .0888 .0888 .0888 .0888 .0888 .0888 .0888 .0888 .0888 .0888 .0 885.0885 .0885 .0885 .0885 .0885 .0885 .0885 .0885 .0885 .0885 .0885 .0885 .0885 .0885 .0885 .0 880.0880 .0880 .0880 .0880 .0880 .0880 .0880 .0880 .0880 .0880 .0880 .0880 .0880 .0880 .0880 .0 875.0875 .0875 .0875 .0875 .0875 .0875 .0875 .0875 .0875 .0875 .0875 .0875 .0875 .0875 .0875 .0 872.5872 .5872 .5872 .5872 .5872 .5872 .5872 .5872 .5872 .5870 .9
5
1.0
(16F5.1)
$-1$
START HEAD 4

885.0885 .0885 .0885 .0885 .0885 .0885 .0885 .0885 .0885 .0885 .0885 .0885 .0885 .0885 .0885 .0 885.0885 .0885 .0885 .0885 .0885 .0885 .0885 .0885 .0885 .0885 .0885 .0885 .0885 .0885 .0885 .0 885.0885 .0885 .0885 .0885 .0885 .0885 .0885 .0885 .0885 .0885 .0885 .0885 .0885 .0885 .0885 .0 880.0880 .0880 .0880 .0880 .0880 .0880 .0880 .0880 .0880 .0880 .0880 .0880 .0880 .0880 .0880 .0 875.0875 .0875 .0875 .0875 .0875 .0875 .0875 .0875 .0875 .0875 .0875 .0875 .0875 .0875 .0875 .0 872.5872 .5872 .5872 .5872 .5872 .5872 .5872 .5872 .5872 .5868 .6
5
1.0
(16F5.1)
$-1$
START HEAD 5

884.9884 .5884 .5884 .5884 .5884 .5884 .5884 .5884 .5884 .5884 .5884 .5884 .5884 .5884 .5884 .5 884.5884 .5884 .5884 .5884 .5884 .5884 .5884 .5884 .5884 .5884 .5884 .5884 .5884 .5884 .5884 .5 884.5884 .5884 .5884 .5884 .5884 .5884 .5884 .5884 .5884 .5884 .5884 .5884 .5884 .5884 .5884 .5 880.0880 .0880 .0880 .0880 .0880 .0880 .0880 .0880 .0880 .0880 .0880 .0880 .0880 .0880 .0880 .0 875.0875 .0875 .0875 .0875 .0875 .0875 .0875 .0875 .0875 .0875 .0875 .0875 .0875 .0875 .0875 .0 873.0873 .0873 .0873 .0873 .0873 .0873 .0873 .0873 .0873 .0872 .7
5
1.0
$(16 \mathrm{~F} 5.1)$
$-1$
START HEAD 6

885.2885 .0885 .0885 .0885 .0885 .0885 .0885 .0885 .0885 .0885 .0885 .0885 .0885 .0885 .0885 .0 885.0885 .0885 .0885 .0885 .0885 .0885 .0885 .0885 .0885 .0885 .0885 .0885 .0885 .0885 .0885 .0 885.0885 .0885 .0885 .0885 .0885 .0885 .0885 .0885 .0885 .0885 .0885 .0885 .0885 .0885 .0885 .0 880.0880 .0880 .0880 .0880 .0880 .0880 .0880 .0880 .0880 .0880 .0880 .0880 .0880 .0880 .0880 .0 875.0875 .0875 .0875 .0875 .0875 .0875 .0875 .0875 .0875 .0875 .0875 .0875 .0875 .0875 .0875 .0 872.5872 .5872 .5872 .5872 .5872 .5872 .5872 .5872 .5872 .5868 .6

$5 \quad 1.0 \quad(16 \mathrm{~F} 5.1) \quad-1 \quad$ START HEAD 7

878.0877 .0877 .0877 .0877 .0877 .0877 .0877 .0877 .0877 .0877 .0877 .0877 .0877 .0877 .0877 .0 875.0875 .0875 .0875 .0875 .0875 .0875 .0875 .0875 .0875 .0875 .0875 .0875 .0875 .0875 .0875 .0 875.0875 .0875 .0875 .0875 .0875 .0875 .0875 .0875 .0875 .0875 .0875 .0875 .0875 .0875 .0875 .0 875.0875 .0875 .0875 .0875 .0875 .0875 .0875 .0875 .0875 .0875 .0875 .0875 .0875 .0875 .0875 .0 870.0870 .0870 .0870 .0870 .0870 .0870 .0870 .0870 .0870 .0870 .0870 .0870 .0870 .0870 .0870 .0 870.0870 .0870 .0870 .0870 .0870 .0870 .0870 .0870 .0870 .0864 .0
5
1.0
(16F5.1)
$-1$
START HEAD 8

805.0805 .0805 .0805 .0805 .0805 .0805 .0805 .0805 .0805 .0805 .0805 .0805 .0805 .0805 .0805 .0 805.0805 .0805 .0805 .0805 .0805 .0805 .0805 .0805 .0805 .0805 .0805 .0805 .0805 .0805 .0805 .0 805.0805 .0805 .0805 .0805 .0805 .0805 .0805 .0805 .0805 .0805 .0805 .0805 .0805 .0805 .0805 .0 805.0805 .0805 .0805 .0805 .0805 .0805 .0805 .0805 .0805 .0805 .0805 .0805 .0805 .0805 .0805 .0 804.0804 .0804 .0804 .0804 .0804 .0804 .0804 .0804 .0804 .0804 .0804 .0804 .0804 .0804 .0804 .0 803.0803 .0803 .0803 .0803 .0803 .0803 .0803 .0803 .0803 .0803 .0
31536000 .
1
1.0 
Listing 2. Input values for the BCF package of the MODULAR program

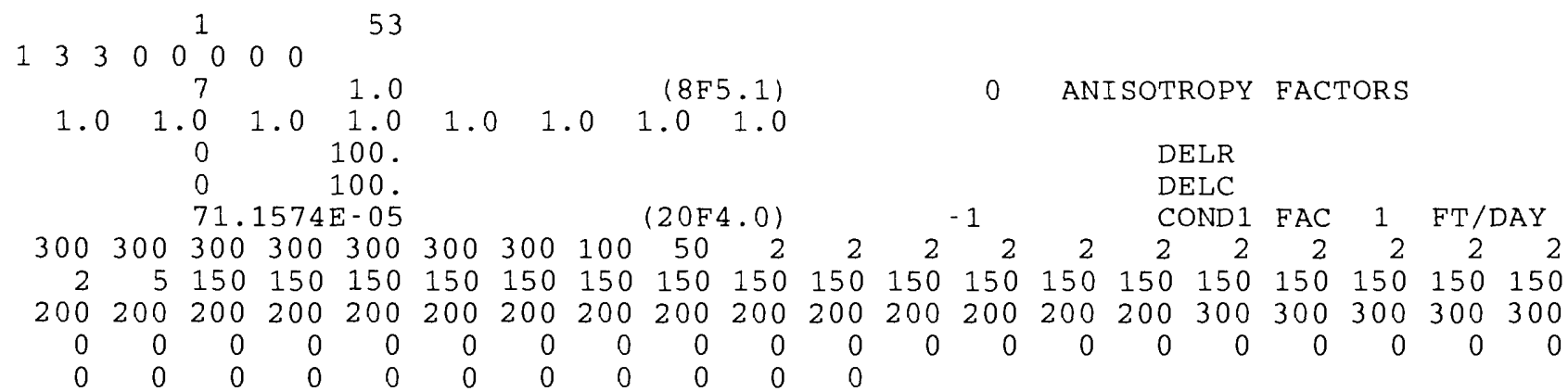

\begin{tabular}{|c|c|c|c|c|c|c|c|c|c|c|c|c|c|c|c|c|c|c|c|}
\hline & & 7 & & 1.0 & & & & $(20 \mathrm{~F}$ & $4.0)$ & & & -1 & & & & BOTT & $O M E$ & ELEV & \\
\hline 885 & 885 & 880 & 880 & 880 & 875 & 875 & 875 & 870 & 870 & 870 & 865 & 865 & 865 & 860 & 860 & 865 & 870 & 870 & 875 \\
\hline 875 & 875 & 875 & 875 & 875 & 875 & 875 & 875 & 875 & 875 & 875 & 875 & 875 & 875 & 875 & 875 & 875 & 875 & 875 & 875 \\
\hline 310 & 870 & 870 & 870 & 870 & 870 & 870 & 870 & 870 & 870 & 870 & 870 & 870 & 870 & 875 & 875 & 875 & 875 & 875 & 875 \\
\hline 0 & & 0 & 0 & 0 & 0 & 0 & 0 & 0 & 0 & 0 & 0 & 0 & 0 & 0 & 0 & 0 & 0 & 0 & \\
\hline 0 & & 0 & 0 & 0 & 0 & 0 & 0 & 0 & 0 & 0 & & & & & & & & & \\
\hline
\end{tabular}

\begin{tabular}{|c|c|c|c|c|}
\hline 7 & 1.0 & $(5 \mathrm{G} 16.4)$ & VCONT LAYERS 12 & \\
\hline $0.2569 D-07$ & $0.4620 \mathrm{D}-07$ & $0.7690 \mathrm{D}-07$ & $0.7694 \mathrm{D}-07$ & $0.7697 D-07$ \\
\hline $0.1153 D-06$ & $0.1154 \mathrm{D}-06$ & $0.1147 D-06$ & $0.1132 \mathrm{D}-06$ & $0.1006 D-07$ \\
\hline $0.1006 \mathrm{D}-07$ & $0.8903 D-08$ & $0.8903 D-08$ & $0.8735 D-08$ & $0.7716 \mathrm{D}-08$ \\
\hline $0.7716 \mathrm{D}-08$ & $0.9448 D-08$ & $0.1129 \mathrm{D}-07$ & $0.1157 D-07$ & $0.1447 D-07$ \\
\hline $0.1653 \mathrm{D}-07$ & $0.1653 \mathrm{D}-07$ & $0.2480 \mathrm{D}-04$ & $0.2480 \mathrm{D}-04$ & $0.2480 D-04$ \\
\hline $0.2480 D-04$ & $0.2170 \mathrm{D}-04$ & $0.2170 \mathrm{D}-04$ & $0.2170 \mathrm{D}-04$ & $0.2170 \mathrm{D}-04$ \\
\hline $0.2170 \mathrm{D}-04$ & $0.2170 \mathrm{D}-04$ & $0.2170 \mathrm{D}-04$ & $0.2170 \mathrm{D}-04$ & $0.2170 \mathrm{D}-04$ \\
\hline $0.1929 D-04$ & $0.1929 D-04$ & $0.1929 \mathrm{D}-04$ & $0.1736 \mathrm{D}-04$ & $0.2284 \mathrm{D}-06$ \\
\hline $0.1781 D-04$ & $0.1781 D-04$ & $0.1653 D-04$ & $0.1653 \mathrm{D}-04$ & $0.1543 D-04$ \\
\hline $0.1447 D-04$ & $0.1362 D-04$ & $0.1362 \mathrm{D}-04$ & $0.1286 D-04$ & $0.1286 \mathrm{D}-04$ \\
\hline $0.1218 \mathrm{D}-04$ & $0.1157 D-04$ & $0.1157 \mathrm{D}-04$ & $0.1102 \mathrm{D}-04$ & $0.2272 \mathrm{D}-06$ \\
\hline $0.2284 D-06$ & $0.2283 D-06$ & $0.2281 D-06$ & $0.2281 D-06$ & $0.2281 D-06$ \\
\hline $0.0000 \mathrm{D} \cdot 06$ & $0.0000 D-06$ & $0.0000 \mathrm{D}-06$ & $0.0000 D-06$ & $0.0000 \mathrm{D}-06$ \\
\hline $0.0000 D-06$ & $0.0000 \mathrm{D}-06$ & $0.0000 \mathrm{D}-06$ & $0.0000 \mathrm{D}-06$ & $0.0000 \mathrm{D}-06$ \\
\hline $0.0000 \mathrm{D}-06$ & $0.0000 D-06$ & $0.0000 D-06$ & $0.0000 D-06$ & $0.0000 \mathrm{D}-06$ \\
\hline $0.0000 D-06$ & $0.0000 \mathrm{D}-06$ & $0.0000 D-06$ & $0.0000 \mathrm{D}-06$ & $0.0000 \mathrm{D}-06$ \\
\hline $0.0000 D-06$ & $0.0000 D-04$ & $0.0000 \mathrm{D}-04$ & $0.0000 \mathrm{D}-04$ & $0.0000 D-04$ \\
\hline OOD- 04 & $0.0000 D-04$ & $0.0000 D-07$ & $0.0000 D-07$ & $0.00000-07$ \\
\hline
\end{tabular}

$71.1574 \mathrm{E}-05 \quad$ (20F4.0) $-1 \quad$ COND2 FAC 1 FT/DAY

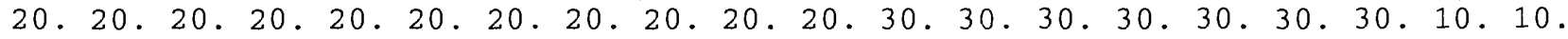
10. 10. 20.20.20.20.20.20.20.20.20.20.20.20.20.20.20.20.20.20. 20.20.20.20.20.20.20.20.20.20.20.20.20.20.20.20.20.20.20.20.

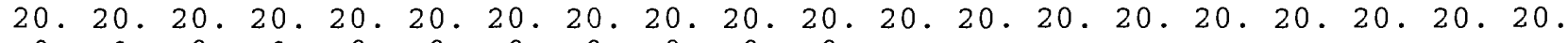
$\begin{array}{lllllllllll}0 & 0 & 0 & 0 & 0 & 0 & 0 & 0 & 0 & 0 & 0\end{array}$
7
1.0
(20F4.0)
$-1$
AQ. BOTTOM

865.865 .865 .865 .865 .865 .865 .865 .860 .860 .860 .860 .860 .855 .855 .855 .855 .860 .865 .865 . 870.870 .870 .870 .870 .870 .870 .870 .870 .870 .870 .870 .870 .870 .870 .870 .870 .870 .870 .865 . 865.865 .865 .865 .865 .865 .865 .865 .865 .865 .865 .865 .865 .865 .865 .865 .865 .865 .865 .865 . 865.865 .870 .870 .870 .870 .870 .870 .865 .865 .865 .865 .865 .870 .870 .870 .870 .870 .870 .870 .

$\begin{array}{lllllllllll}0 & 0 & 0 & 0 & 0 & 0 & 0 & 0 & 0 & 0 & 0\end{array}$ 
Listing 2. Input values for the BCF package of the MODULAR program--Continued

\begin{tabular}{lcccc}
7 & 1.0 & \multicolumn{1}{c}{$(5 G 16.4)$} & \multicolumn{2}{l}{ VCONT LAYERS23 } \\
$0.2571 \mathrm{D}-07$ & $0.4626 \mathrm{D}-07$ & $0.7707 \mathrm{D}-07$ & $0.7707 \mathrm{D}-07$ & $0.7707 \mathrm{D}-07$ \\
$0.1155 \mathrm{D}-06$ & $0.1155 \mathrm{D}-06$ & $0.1155 \mathrm{D}-06$ & $0.1155 \mathrm{D}-06$ & $0.2307 \mathrm{D}-06$ \\
$0.2307 \mathrm{D}-06$ & $0.6614 \mathrm{D}-04$ & $0.6614 \mathrm{D}-04$ & $0.4597 \mathrm{D}-06$ & $0.6614 \mathrm{D}-04$ \\
$0.6614 \mathrm{D}-04$ & $0.4597 \mathrm{D}-06$ & $0.4597 \mathrm{D}-06$ & $0.6614 \mathrm{D}-04$ & $0.1156 \mathrm{D}-06$ \\
$0.8267 \mathrm{D}-04$ & $0.8267 \mathrm{D}-04$ & $0.8267 \mathrm{D}-04$ & $0.8267 \mathrm{D}-04$ & $0.8267 \mathrm{D}-04$ \\
$0.8267 \mathrm{D}-04$ & $0.8267 \mathrm{D}-04$ & $0.8267 \mathrm{D}-04$ & $0.5787 \mathrm{D}-04$ & $0.5787 \mathrm{D}-04$ \\
$0.5787 \mathrm{D}-04$ & $0.5787 \mathrm{D}-04$ & $0.5787 \mathrm{D}-04$ & $0.5787 \mathrm{D}-04$ & $0.5787 \mathrm{D}-04$ \\
$0.5787 \mathrm{D}-04$ & $0.4823 \mathrm{D}-04$ & $0.4823 \mathrm{D}-04$ & $0.4823 \mathrm{D}-04$ & $0.2306 \mathrm{D}-06$ \\
$0.5787 \mathrm{D}-05$ & $0.5787 \mathrm{D}-05$ & $0.5787 \mathrm{D}-05$ & $0.5787 \mathrm{D}-05$ & $0.5787 \mathrm{D}-05$ \\
$0.5787 \mathrm{D}-05$ & $0.5787 \mathrm{D}-05$ & $0.5787 \mathrm{D}-05$ & $0.5787 \mathrm{D}-05$ & $0.5787 \mathrm{D}-05$ \\
$0.5787 \mathrm{D}-05$ & $0.5787 \mathrm{D}-05$ & $0.5787 \mathrm{D}-05$ & $0.5787 \mathrm{D}-05$ & $0.2226 \mathrm{D}-06$ \\
$0.2226 \mathrm{D}-06$ & $0.2226 \mathrm{D}-06$ & $0.2226 \mathrm{D}-06$ & $0.2226 \mathrm{D}-06$ & $0.2226 \mathrm{D}-06$ \\
$0.2269 \mathrm{D}-06$ & $0.2269 \mathrm{D}-06$ & $0.2261 \mathrm{D}-06$ & $0.2261 \mathrm{D}-06$ & $0.2261 \mathrm{D}-06$ \\
$0.2261 \mathrm{D}-06$ & $0.2261 \mathrm{D}-06$ & $0.2261 \mathrm{D}-06$ & $0.1149 \mathrm{D}-06$ & $0.1149 \mathrm{D}-06$ \\
$0.1149 \mathrm{D}-06$ & $0.1149 \mathrm{D}-06$ & $0.1149 \mathrm{D}-06$ & $0.1146 \mathrm{D}-06$ & $0.1146 \mathrm{D}-06$ \\
$0.1146 \mathrm{D}-06$ & $0.1146 \mathrm{D}-06$ & $0.1146 \mathrm{D}-06$ & $0.1146 \mathrm{D}-06$ & $0.1146 \mathrm{D}-06$ \\
$0.0000 \mathrm{D}-06$ & $0.0000 \mathrm{D}-04$ & $0.0000 \mathrm{D}-04$ & $0.0000 \mathrm{D}-04$ & $0.0000 \mathrm{D}-04$ \\
$0.0000 \mathrm{D}-04$ & $0.0000 \mathrm{D}-04$ & $0.0000 \mathrm{D}-04$ & $0.0000 \mathrm{D}-04$ & $0.0000 \mathrm{D}-04$
\end{tabular}

$1.0 \quad(20 \mathrm{~F} 4.0)$

$-1$

AQ. TOP

885.885 .880 .880 .880 .875 .875 .875 .870 .870 .870 .865 .865 .865 .860 .860 .865 .870 .870 .875 . 875.875 .875 .875 .875 .875 .875 .875 .875 .875 .875 .875 .875 .875 .875 .875 .875 .875 .875 .875 . 870.870 .870 .870 .870 .870 .870 .870 .870 .870 .870 .870 .870 .870 .875 .875 .875 .875 .875 .875 . 875.875 .880 .880 .880 .880 .880 .880 .885 .890 .890 .890 .890 .890 .890 .890 .890 .895 .895 .895 . 895.895 .895 .900 .900 .900 .900 .900 .900 .900 .900 .

$71.1574 \mathrm{E}-03$

(20F4.1)

$-1$

COND3 FAC 100 FT/DAY

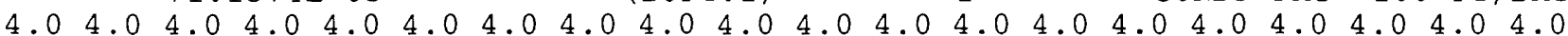
$\begin{array}{llllllllllllllllllllllll}5.0 & 5.0 & 5.0 & 5.0 & 5.0 & 5.0 & 5.0 & 5.0 & 5.0 & 5.0 & 5.0 & 5.0 & 5.0 & 5.0 & 5.0 & 5.0 & 5.0 & 5.0 & 5.0 & 5.0\end{array}$

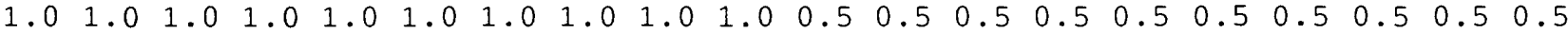

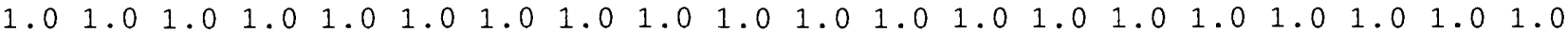

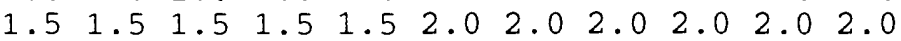

7

1.0

$(20 \mathrm{~F} 4.0)$

$-1$

AQ. BOTTOM

850.850 .850 .850 .850 .850 .850 .845 .845 .845 .845 .845 .845 .840 .840 .840 .840 .845 .845 .845 . 845.845 .845 .845 .845 .845 .845 .845 .850 .850 .850 .850 .850 .850 .850 .850 .845 .845 .845 .845$. 845.845 .845 .845 .845 .845 .845 .845 .845 .845 .845 .845 .845 .845 .845 .845 .845 .845 .845 .845$. 845.845 .845 .845 .845 .845 .845 .845 .850 .850 .850 .850 .850 .850 .850 .850 .850 .850 .850 .850$. 850.850 .850 .850 .850 .850 .850 .850 .850 .855 .855 .

$\begin{array}{lllll}7 & 1.0 & & -1 & \text { VCONT LAYERS34 } \\ 0.2314 \mathrm{D}-09 & 0.2314 \mathrm{D}-09 & 0.2314 \mathrm{D}-09 & 0.2314 \mathrm{D}-09 & 0.2314 \mathrm{D}-09 \\ 0.2314 \mathrm{D}-09 & 0.2314 \mathrm{D}-09 & 0.4625 \mathrm{D}-09 & 0.1138 \mathrm{D}-09 & 0.2237 \mathrm{D}-09 \\ 0.2237 \mathrm{D}-09 & 0.2237 \mathrm{D}-09 & 0.2237 \mathrm{D}-06 & 0.2237 \mathrm{D}-06 & 0.2237 \mathrm{D}-06 \\ 0.1138 \mathrm{D}-06 & 0.0926 \mathrm{D}-05 & 0.1323 \mathrm{D}-05 & 0.0926 \mathrm{D}-05 & 0.0772 \mathrm{D}-05 \\ 0.0772 \mathrm{D}-05 & 0.1929 \mathrm{D}-09 & 0.1929 \mathrm{D}-09 & 0.1929 \mathrm{D}-09 & 0.1929 \mathrm{D}-09 \\ 0.1929 \mathrm{D}-09 & 0.2315 \mathrm{D}-09 & 0.2315 \mathrm{D}-09 & 0.3307 \mathrm{D}-09 & 0.3307 \mathrm{D}-09 \\ 0.3307 \mathrm{D}-09 & 0.3307 \mathrm{D}-09 & 0.3307 \mathrm{D}-09 & 0.3307 \mathrm{D}-09 & 0.4630 \mathrm{D}-09 \\ 0.4630 \mathrm{D}-09 & 0.9259 \mathrm{D}-09 & 0.6614 \mathrm{D}-09 & 0.6614 \mathrm{D}-09 & 0.6614 \mathrm{D}-09 \\ 0.6613 \mathrm{D}-09 & 0.6613 \mathrm{D}-09 & 0.6613 \mathrm{D}-09 & 0.6613 \mathrm{D}-09 & 0.6613 \mathrm{D}-09 \\ 0.6613 \mathrm{D}-09 & 0.6613 \mathrm{D}-09 & 0.6613 \mathrm{D}-09 & 0.6613 \mathrm{D}-09 & 0.6613 \mathrm{D}-09 \\ 0.6613 \mathrm{D}-09 & 0.9629 \mathrm{D}-09 & 0.9629 \mathrm{D}-09 & 0.9629 \mathrm{D}-09 & 0.9629 \mathrm{D}-09 \\ 0.9629 \mathrm{D}-08 & 0.9629 \mathrm{D}-08 & 0.9629 \mathrm{D}-08 & 0.9629 \mathrm{D}-08 & 0.9629 \mathrm{D}-08 \\ 0.1897 \mathrm{D}-06 & 0.1897 \mathrm{D}-06 & 0.1891 \mathrm{D}-06 & 0.1891 \mathrm{D}-06 & 0.1891 \mathrm{D}-06 \\ 0.1891 \mathrm{D}-06 & 0.1891 \mathrm{D}-06 & 0.1891 \mathrm{D}-06 & 0.1377 \mathrm{D}-06 & 0.1377 \mathrm{D}-06 \\ 0.1377 \mathrm{D}-06 & 0.1377 \mathrm{D}-06 & 0.1377 \mathrm{D}-06 & 0.1372 \mathrm{D}-06 & 0.1372 \mathrm{D}-06 \\ 0.1372 \mathrm{D}-08 & 0.1372 \mathrm{D}-08 & 0.1372 \mathrm{D}-08 & 0.1372 \mathrm{D}-08 & 0.1372 \mathrm{D}-08 \\ 0.1542 \mathrm{D}-08 & 0.1542 \mathrm{D}-08 & 0.1542 \mathrm{D}-08 & 0.1542 \mathrm{D}-08 & 0.1542 \mathrm{D}-08 \\ 0.1542 \mathrm{D}-08 & 0.1361 \mathrm{D}-08 & 0.1361 \mathrm{D}-08 & 0.1360 \mathrm{D}-08 & 0.1157 \mathrm{D}-08 \\ 0.1157 \mathrm{D}-08 & & & & \end{array}$




\section{Listing 2. Input values for the BCF package of the MODULAR program--Continued}
7
1.0
(20F4.0)
$-1$
AQ . TOP

865.865 .865 .865 .865 .865 .865 .865 .860 .860 .860 .860 .860 .855 .855 .855 .855 .860 .865 .865 . 870.870 .870 .870 .870 .870 .870 .870 .870 .870 .870 .870 .870 .870 .870 .870 .870 .870 .870 .865 . 865.865 .865 .865 .865 .865 .865 .865 .865 .865 .865 .865 .865 .865 .865 .865 .865 .865 .865 .865 . 865.865 .870 .870 .870 .870 .870 .870 .865 .865 .865 .865 .865 .870 .870 .870 .870 .870 .870 .870 . 875.875 .875 .875 .875 .875 .875 .875 .880 .880 .880 .

\begin{tabular}{|c|c|c|c|c|c|c|c|c|c|c|c|c|c|c|c|}
\hline \multicolumn{6}{|c|}{$71.1574 \mathrm{E}-05$} & \multicolumn{3}{|c|}{$(16 \mathrm{~F} 5.0)$} & \multicolumn{2}{|c|}{-1} & \multirow{2}{*}{$\begin{array}{c}\text { TRANS } 4 \\
20\end{array}$} & \multirow{2}{*}{$\begin{array}{l}\text { FAC } \\
20\end{array}$} & \multirow{2}{*}{$\begin{array}{r}1.0 \\
20\end{array}$} & \multicolumn{2}{|c|}{$\mathrm{FT} 2 / \mathrm{DAY}$} \\
\hline 20 & 200 & 200 & 200 & 200 & 200 & 200 & 100 & 50 & 20 & 20 & & & & 20 & 5 \\
\hline & 150 & 375 & 375 & 375 & 37 & 375 & 375 & 375 & 375 & 400 & 400 & 300 & 300 & 300 & 30 \\
\hline & 300 & 200 & 200 & 300 & & 300 & & & 300 & 300 & 300 & 300 & 300 & 300 & 30 \\
\hline & 300 & 300 & 750 & 750 & & 750 & 7 & 750 & 750 & 750 & 750 & 750 & 750 & 750 & 1 \\
\hline & 750 & 750 & 750 & 900 & 900 & 900 & 9 & 900 & 900 & 900 & 900 & 900 & 900 & 900 & 90 \\
\hline & 300 & 300 & 300 & 300 & 300 & 350 & 350 & 350 & 400 & 400 & & & & & \\
\hline
\end{tabular}
$0.1929 D-09$
1.0
$0.2314 D-09$
0. 2104D-09
0.1929D-09
$0.2314 \mathrm{D}-09$
$0.2104 \mathrm{D}-09$
$0.0842 \mathrm{D}-05$
$0.1118 D-07$
$0.1929 \mathrm{D}-09$
$0.1929 D-09$
$0.2315 \mathrm{D}-09$
$0.3307 \mathrm{D}-09$
$0.9259 \mathrm{D}-09$
$0.4630 \mathrm{D}-09$
$0.6614 \mathrm{D}-09$
$0.6614 D-09$
$0.6614 \mathrm{D}-09$
$0.9644 D-08$
$0.6614 \mathrm{D}-09$
$0.9643 \mathrm{D}-08$
$0.1897 \mathrm{D}-06$
$0.1897 \mathrm{D}-06$
$0.1867 \mathrm{D}-06$
$0.1867 \mathrm{D}-06$
$0.1736 \mathrm{D}-06$
$0.1736 \mathrm{D}-06$
$0.1372 \mathrm{D}-06$
$0.1372 \mathrm{D}-06$
$0.1541 D-07$
$0.1541 \mathrm{D}-07$
$0.1541 \mathrm{D}-07$
$0.1156 \mathrm{D}-07$
$0.1361 \mathrm{D}-07$

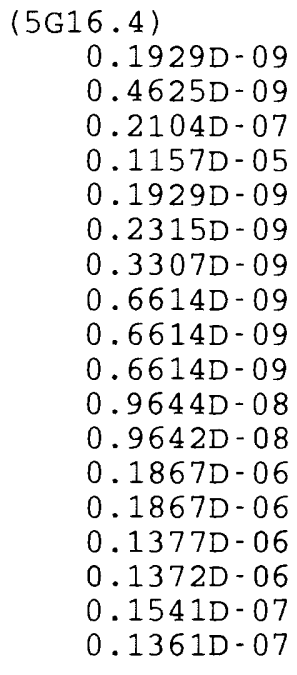

(16F5.0)

50

100

4000

3000

$71.1574 \mathrm{E}-05$
- 1 VCONT LAYERS45

$\begin{array}{ll}0.1929 D-09 & 0.1929 D-09 \\ 0.1118 D-09 & 0.2104 D-09 \\ 0.2104 D-07 & 0.2104 D-07 \\ 0.0842 D-05 & 0.0772 D-05 \\ 0.1929 D-09 & 0.1929 D-09 \\ 0.3307 D-09 & 0.3307 D-09 \\ 0.3307 D-09 & 0.4630 D-09 \\ 0.6614 D-09 & 0.6614 D-09 \\ 0.6614 D-09 & 0.6614 D-09 \\ 0.6614 D-09 & 0.6614 D-09 \\ 0.9644 D-08 & 0.9644 D-08 \\ 0.9642 D-08 & 0.9642 D-08 \\ 0.1867 D-06 & 0.1867 D-06 \\ 0.1736 D-06 & 0.1736 D-06 \\ 0.1377 D-06 & 0.1372 D-06 \\ 0.1372 D-06 & 0.1372 D-06 \\ 0.1541 D-07 & 0.1541 D-07 \\ 0.1361 D-07 & 0.1156 D-07\end{array}$

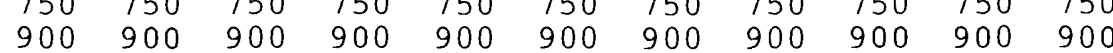

- 1 TRANS5 FAC 1.0

40004000400040003000

$40004000 \quad 4000 \quad 40004000$

$100 \quad 100 \quad 3000 \quad 30003000$

300011251125

$750 \quad 900 \quad 900$

$\begin{array}{ll}750 & 750 \\ 900 & 900\end{array}$ 


\section{Listing 2. Input values for the BCF package of the MODULAR program--Continued}

\begin{tabular}{|c|c|c|c|c|}
\hline 7 & 1.0 & $(5 G 16.4)$ & VCONT LAYERS56 & \\
\hline $0.1109 D-09$ & $0.1109 D-09$ & $0.1109 D-09$ & $0.1109 D-09$ & $0.1109 D-09$ \\
\hline $0.3017 D-09$ & $0.2978 D-09$ & $0.2978 D-09$ & $0.2903 D-09$ & $0.3800 D-09$ \\
\hline $0.3800 \mathrm{D}-06$ & $0.3800 \mathrm{D}-06$ & $0.3800 D-06$ & $0.3800 \mathrm{D}-06$ & $0.3800 D-06$ \\
\hline $0.3283 D-05$ & $0.4583 D-05$ & $0.4563 D-05$ & $0.4563 D-05$ & $0.4583 D-05$ \\
\hline $583 D \cdot 05$ & $0.4334 \mathrm{D}-06$ & $0.4334 \mathrm{D}-06$ & $0.4334 \mathrm{D}-06$ & $0.4334 \mathrm{D}-06$ \\
\hline $34 D-06$ & $0.4334 \mathrm{D}-06$ & $0.4334 D-06$ & $34 D-06$ & $0.4334 \mathrm{D}-06$ \\
\hline $334 D-06$ & $0.4334 \mathrm{D}-06$ & $0.4334 D-06$ & $0.4375 D-06$ & $0.4375 D-06$ \\
\hline $300 D-06$ & $0.3800 D-06$ & $0.4216 \mathrm{D}-06$ & $359 D-06$ & $0.4859 \mathrm{D}-06$ \\
\hline $359 D-06$ & $0.5735 D-06$ & $0.5735 D-06$ & $35-06$ & $0.6995 \mathrm{D}-06$ \\
\hline $139 D-06$ & $0.7139 D-06$ & $0.9203 D-06$ & $0.9203 D-06$ & $0.9203 D-06$ \\
\hline $203 D-06$ & $0.9203 D-06$ & $0.1295 D-04$ & $95 D-04$ & $0.1295 \mathrm{D}-04$ \\
\hline $295 D-04$ & $0.1939 D-04$ & $0.1661 D-04$ & $0.3472 D-04$ & $0.3472 \mathrm{D}-04$ \\
\hline $0.1157 D-04$ & $0.1157 D-04$ & $0.1157 \mathrm{D}-06$ & $0.1157 \mathrm{D}-06$ & $0.1157 D-06$ \\
\hline $0.1157 D-06$ & $0.1157 D-06$ & $0.1157 D-06$ & $0.1157 D-06$ & $0.1157 \mathrm{D}-06$ \\
\hline $57 D-06$ & $0.1157 D-06$ & $0.4596 D-08$ & $0.4596 D-08$ & $0.3264 D-08$ \\
\hline $0.2496 \mathrm{D}-08$ & $0.2496 \mathrm{D}-08$ & $0.2496 \mathrm{D}-08$ & $0.2496 \mathrm{D}-08$ & $0.2496 D-08$ \\
\hline $6 D-08$ & $0.2496 D-08$ & $0.2496 D-08$ & $0.2496 \mathrm{D}-08$ & $0.2496 D-08$ \\
\hline $1-08$ & $2867 D-08$ & $67 D-08$ & 08 & $0.2496 \mathrm{D}$ \\
\hline
\end{tabular}

$71.1574 \mathrm{E}-05$

$6875 \quad 6875 \quad 6875 \quad 6875$ $5500 \quad 5500 \quad 5500 \quad 5500$

$4125 \quad 4125 \quad 4125 \quad 4125$

$19251925 \quad 1650 \quad 1650$

1000100010001000

5500
$(16 \mathrm{~F} 5.0)$

$6875550055005500 \quad 5500 \quad 5500$

$\begin{array}{llllll}4125 & 4125 & 4125 & 4125 & 4125 & 4125\end{array}$

$41253850 \quad 3575 \quad 3300 \quad 3300 \quad 3025$

$1500 \quad 1500 \quad 15001500 \quad 15001500$

$1000100010001000 \quad 26002750$

550055005500550055005500

$-1$ $\begin{array}{llllll}5500 & 5500 & 5500 & 5500 & 5500 & 5500\end{array}$ $\begin{array}{llllll}4125 & 4125 & 4125 & 4125 & 4125 & 4125\end{array}$ $\begin{array}{lllllll}3025 & 2750 & 2475 & 2200 & 2200 & 1925\end{array}$ $\begin{array}{llllll}1375 & 1375 & 1375 & 1375 & 1000 & 1000\end{array}$ $412555005500 \quad 5500 \quad 5500 \quad 5500$ 5500

$7 \quad 1.0$
$0.2315 D-10$
$0.2315 D-10$
$0.2315 D-10$
$0.2315 D-10$
$0.2315 D-10$
$0.2315 D-10$
$0.2315 D-10$
$0.2315 D-10$
$0.2315 D-10$
$0.2894 D-07$
$0.2894 D-07$
$0.2894 D-07$
$0.2894 D-07$
$0.2300 D-07$
$0.2300 D-07$
$0.2315 D-10$
$0.2315 D-10$
$0.2315 D-10$
$0.2315 D-10$
$0 \quad .03617$
$01.1574 E-11$
$0 \quad .12731$

$\begin{array}{ll} & (5 G 16.4) \\ 0.2315 D-10 & 0.2315 D-10 \\ 0.2315 D-10 & 0.2315 D-10 \\ 0.2315 D-10 & 0.2315 D-10 \\ 0.2315 D-10 & 0.2315 D-10 \\ 0.2315 D-10 & 0.2315 D-10 \\ 0.2315 D-10 & 0.2315 D-10 \\ 0.2315 D-10 & 0.2315 D-10 \\ 0.2315 D-10 & 0.2315 D-10 \\ 0.2315 D-10 & 0.2315 D-10 \\ 0.2894 D-07 & 0.2894 D-07 \\ 0.2894 D-07 & 0.2894 D-07 \\ 0.2894 D-07 & 0.2894 D-07 \\ 0.2894 D-07 & 0.2300 D-07 \\ 0.2300 D-07 & 0.2300 D-07 \\ 0.2300 D-07 & 0.2315 D-10 \\ 0.2315 D-10 & 0.2315 D-10 \\ 0.2315 D-10 & 0.2315 D-10 \\ 0.2315 D-10 & 0.2315 D-10\end{array}$
$-1$

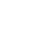

VCONT LAYERS 67

$0.2315 D-10$
$0.2315 D-10$
$0.2315 D-10$
$0.2315 D-10$
$0.2315 D-10$
$0.2315 D-10$
$0.2315 D-10$
$0.2315 D-10$
$0.2315 D-10$
$0.2894 D-07$
$0.2894 D-07$
$0.2894 D-07$
$0.2300 D-07$
$0.2300 D-07$
$0.2315 D-10$
$0.2315 D-10$
$0.2315 D-10$
$0.2315 D-10$

$0.2315 \mathrm{D}-10$

$0.2315 \mathrm{D}-10$

$0.2315 \mathrm{D}-10$

$0.2315 D-10$

$0.2315 \mathrm{D}-10$

$0.2315 \mathrm{D}-10$

$0.2315 D-10$

$0.2315 \mathrm{D}-10$

$0.2315 D-10$

$0.2894 \mathrm{D}-07$

$0.2894 \mathrm{D}-07$

$0.2894 \mathrm{D}-07$

$0.2300 \mathrm{D}-07$

$0.2300 \mathrm{D}-07$

$0.2315 \mathrm{D}-10$

$0.2315 \mathrm{D}-10$

$0.2315 \mathrm{D}-10$

$0.2315 D-10$ 
Listing 3. Input values for the RECHARGE package of the MODULAR program

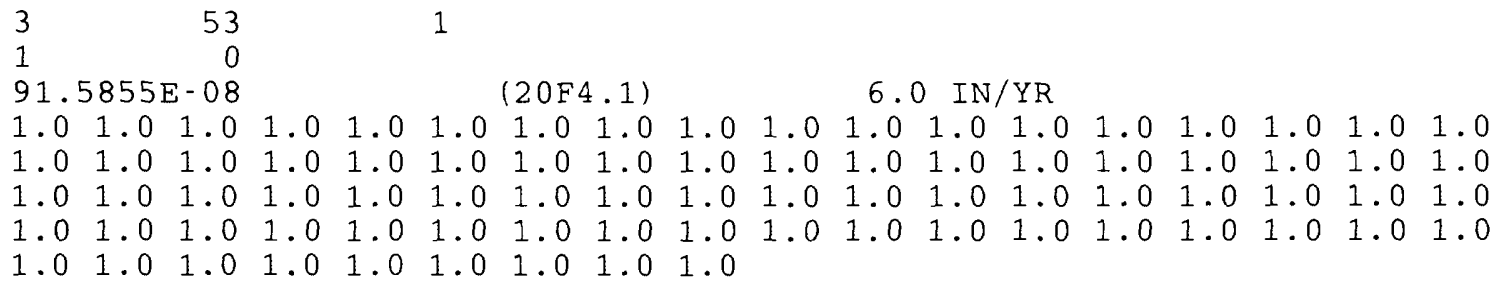

\section{Listing 4. Input values for the SSOR package of the MODULAR program}

75

1.0

0.01

1

Listing 5. Input values for the Output Control Option of the BASIC package of the MODULAR program

$\begin{array}{rrrr}0 & 0 & 54 & 0 \\ 0 & -1 & -1 & -1 \\ 1 & 1 & 1 & 1\end{array}$


Listing 6. Input values for the main data file of the particle-tracking post-processing program

\begin{tabular}{|c|c|c|c|c|c|c|c|c|c|c|c|c|c|c|c|c|c|c|c|}
\hline & & 91 & & 1 & & & 8 & & 2 & & & 0 & & & & & & & \\
\hline & 9 & & & & & & & 53 & 54 & & & & & & & & & & \\
\hline 13 & 30 & 00 & $\begin{array}{ll}0 & 0\end{array}$ & & & & & & & & & & & & & & & & \\
\hline $0 \quad 0$ & 00 & $\begin{array}{ll}0 & 1\end{array}$ & 10 & & & & & & & & & & & & & & & & \\
\hline & & 0 & & 100. & & & & & & & & 0 & & ELR & & & & & \\
\hline & & 0 & & 100. & & & & & & & & 0 & & ELC & & & & & \\
\hline & & 15 & & 1.0 & & & & $(20 \mathrm{~F}$ & $4.0)$ & & & 1 & & & & ВОTТ & L1 & & \\
\hline 885 & 885 & 880 & 880 & 880 & 875 & 875 & 875 & 870 & 870 & 870 & 865 & 865 & 865 & 860 & 860 & 865 & 870 & $\varepsilon 70$ & 87 \\
\hline 875 & 875 & 875 & 875 & 875 & 875 & 875 & 875 & 875 & 875 & 875 & 875 & 875 & 875 & 875 & 875 & 875 & 875 & $\varepsilon 75$ & $8^{\prime}$ \\
\hline 870 & 870 & 870 & 870 & 870 & 870 & 870 & 870 & 870 & 870 & 870 & 870 & 870 & 870 & 875 & 875 & 875 & 875 & $\varepsilon 75$ & $8^{\prime}$ \\
\hline 0 & 0 & 0 & 0 & 0 & 0 & 0 & 0 & 0 & 0 & 0 & 0 & 0 & 0 & 0 & 0 & 0 & 0 & 0 & \\
\hline 0 & 0 & 0 & 0 & 0 & 0 & 0 & 0 & 0 & 0 & 0 & & & & & & & & & \\
\hline
\end{tabular}

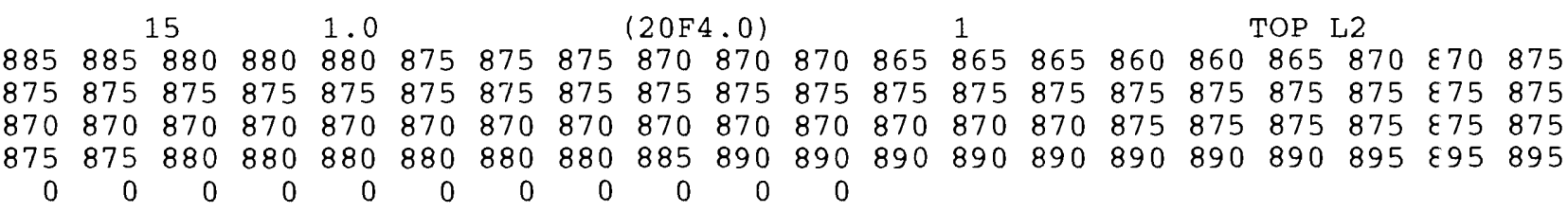
15
1.0
(20F4.0)
1
BOTT L2

865.865 .865 .865 .865 .865 .865 .865 .860 .860 .860 .860 .860 .855 .855 .855 .855 .860 .865 .865 . 870.870 .870 .870 .870 .870 .870 .870 .870 .870 .870 .870 .870 .870 .870 .870 .870 .870 .870 .865 . $865.865 .865 .865 .865 .865 .865 .865 .865 .865 .865 .865 .865 .865 .865 .865 .865 .865 . \varepsilon 65.865$. 865.865 .870 .870 .870 .870 .870 .870 .865 .865 .865 .865 .865 .870 .870 .870 .870 .870 .870 .870 .

$$
\begin{array}{lllllllllll}
0 & 0 & 0 & 0 & 0 & 0 & 0 & 0 & 0 & 0 & 0
\end{array}
$$
15
1.0
(20F4.0)
1
TOP L 3

$865.865 .865 .865 .865 .865 .865 .865 .860 .860 .860 .860 .860 .855 .855 .855 .855 .860 . \varepsilon 65.865$. $870.870 .870 .870 .870 .870 .870 .870 .870 .870 .870 .870 .870 .870 .870 .870 .870 .870 . \varepsilon 70.865$. 865.865 .865 .865 .865 .865 .865 .865 .865 .865 .865 .865 .865 .865 .865 .865 .865 .865 .865 .865 . $865.865 .870 .870 .870 .870 .870 .870 .865 .865 .865 .865 .865 .870 .870 .870 .870 .870 . \varepsilon 70.870$. 875.875 .875 .875 .875 .875 .875 .875 .880 .880 .880 .
15
1.0
$(20 F 4.0)$
1
BOTT L3

850.850 .850 .850 .850 .850 .850 .845 .845 .845 .845 .845 .845 .840 .840 .840 .840 .845 .845 .845 . 845.845 .845 .845 .845 .845 .845 .845 .850 .850 .850 .850 .850 .850 .850 .850 .845 .845 .845 .845 . 845.845 .845 .845 .845 .845 .845 .845 .845 .845 .845 .845 .845 .845 .845 .845 .845 .845 .845 .845 . 845.845 .845 .845 .845 .845 .845 .845 .850 .850 .850 .850 .850 .850 .850 .850 .850 .850 .850 .850 . 850.850 .850 .850 .850 .850 .850 .850 .850 .855 .855 .
15
1.0
$(20 F 4.0)$
1
TOP L4

850.850 .850 .850 .850 .850 .850 .845 .845 .845 .845 .845 .845 .840 .840 .840 .840 .845 .845 .845 . 845.845 .845 .845 .845 .845 .845 .845 .850 .850 .850 .850 .850 .850 .850 .850 .845 .845 .845 .845 . 845.845 .845 .845 .845 .845 .845 .845 .845 .845 .845 .845 .845 .845 .845 .845 .845 .845 .845 .845 . 845.845 .845 .845 .845 .845 .845 .845 .850 .850 .850 .850 .850 .850 .850 .850 .850 .850 .850 .850 . 850.850 .850 .850 .850 .850 .850 .850 .850 .855 .855 .

15

$1.0 \quad(20 \mathrm{~F} 4.0)$

$\begin{array}{lllllllllll}820 & 820 & 820 & 820 & 820 & 820 & 825 & 825 & 835 & 835 & 8\end{array}$

$\begin{array}{lllllllllll}830 & 830 & 830 & 830 & 830 & 830 & 830 & 830 & 830 & 830\end{array}$

$\begin{array}{llllllllll}820 & 820 & 820 & 820 & 820 & 820 & 820 & 820 & 820 & 820\end{array}$

820

\section{5}

$\begin{array}{llllllllllll}820 & 820 & 820 & 820 & 820 & 820 & 825 & 825 & 835 & 835\end{array}$

$\begin{array}{lllllllllll}830 & 830 & 830 & 830 & 830 & 830 & 830 & 830 & 830 & 830\end{array}$

$\begin{array}{llllllllll}820 & 820 & 820 & 820 & 820 & 820 & 820 & 820 & 820 & 820\end{array}$

$\begin{array}{llll}820 & 820 & 820 & 820\end{array}$
820 $\begin{array}{llllll}820 & 815 & 815 & 815 & 815 & 815\end{array}$
1 BOTT L4

$\begin{array}{llllllllll}843 & 843 & 843 & 838 & 838 & 835 & 830 & 830 & 825 & 820\end{array}$ $\begin{array}{llllllllll}835 & 835 & 835 & 835 & 840 & 840 & 835 & 830 & 830 & 830\end{array}$ $\begin{array}{llllllllll}830 & 820 & 820 & 820 & 820 & 820 & 820 & 820 & 820 & 820\end{array}$ $\begin{array}{llllllllll}820 & 820 & 820 & 820 & 820 & 820 & 820 & 820 & 820 & 820\end{array}$ 815

1 TOP L5

$\begin{array}{llllllllll}843 & 843 & 843 & 838 & 838 & 835 & 830 & 830 & 825 & 820\end{array}$ $\begin{array}{llllllllll}835 & 835 & 835 & 835 & 840 & 840 & 835 & 830 & 830 & 830\end{array}$ $\begin{array}{llllllllll}830 & 820 & 820 & 820 & 820 & 820 & 820 & 820 & 820 & 820\end{array}$ $\begin{array}{llllllllll}820 & 820 & 820 & 820 & 820 & 820 & 820 & 820 & 820 & 820\end{array}$ 


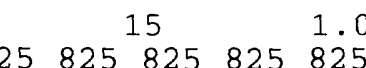

$\begin{array}{llllllllll}825 & 825 & 825 & 825 & 825 & 820 & 825 & 825 & 823 & 8\end{array}$

$\begin{array}{llllllllll}810 & 810 & 810 & 810 & 810 & 810 & 815 & 815 & 825 & 825\end{array}$

$\begin{array}{llllllllllllllll}825 & 825 & 825 & 825 & 825 & 820 & 820 & 820 & 820 & 820 & 820 & 810 & 810 & 810\end{array}$

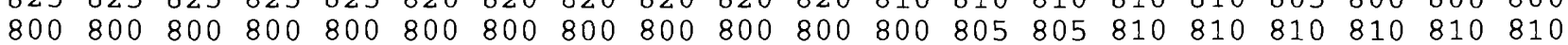

$\begin{array}{lllllllllll}810 & 810 & 810 & 810 & 810 & 810 & 810 & 810 & 810 & 805 & 805\end{array}$

BOTT L5

$\begin{array}{llllll}18 & 820 & 820 & 820 & 815 & 810\end{array}$

$\begin{array}{llllll}30 & 830 & 825 & 825 & 825 & 825\end{array}$
15

1.0

(20F4.0)

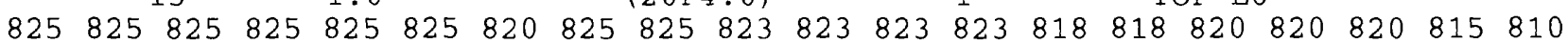

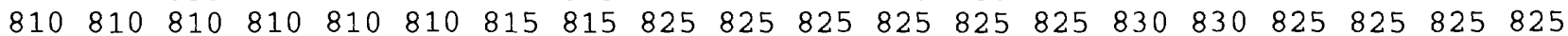

$\begin{array}{llllllllllllllllllll}825 & 825 & 825 & 825 & 825 & 820 & 820 & 820 & 820 & 820 & 820 & 810 & 810 & 810 & 810 & 810 & 805 & 800 & 800 & 800\end{array}$

$\begin{array}{llllllllllllllllllll}800 & 800 & 800 & 800 & 800 & 800 & 800 & 800 & 800 & 800 & 800 & 800 & 805 & 805 & 810 & 810 & 810 & 810 & 810 & 810\end{array}$ $\begin{array}{lllllllllll}810 & 810 & 810 & 810 & 810 & 810 & 810 & 810 & 810 & 805 & 805\end{array}$
15

$150050.0)$

$\begin{array}{llllllllllll}795 & 795 & 795 & 795 & 795 & 795 & 800 & 800 & 810 & 810 & 810 & 810\end{array}$

$\begin{array}{llllllllllllll}813 & 814 & 814 & 815 & 816 & 812 & 812 & 813 & 813 & 813 & 814 & 804 & 805 & 805\end{array}$

$\begin{array}{llllllllllllll}799 & 799 & 799 & 799 & 799 & 799 & 799 & 799 & 799 & 799 & 799 & 799 & 795 & 79\end{array}$

$\begin{array}{lllllllllll}790 & 790 & 790 & 790 & 790 & 790 & 790 & 790 & 790 & 785 & 785\end{array}$

15

1.0

(20F4.0)

$\begin{array}{llllllllllll}795 & 795 & 795 & 795 & 795 & 800 & 795 & 800 & 800 & 803 & 803 & 803\end{array}$

$\begin{array}{lllllllllllll}790 & 790 & 790 & 790 & 790 & 790 & 795 & 795 & 805 & 805 & 805 & 805 & 805\end{array}$

$\begin{array}{llllllllllllllll}794 & 794 & 794 & 794 & 794 & 794 & 794 & 794 & 794 & 794 & 794 & 794 & 790 & 790\end{array}$

$\begin{array}{lllllllllll}785 & 785 & 785 & 785 & 785 & 785 & 785 & 785 & 785 & 780 & 780\end{array}$ $\begin{array}{llllllllllllll}808 & 809 & 809 & 810 & 811 & 807 & 807 & 808 & 808 & 808 & 809 & 799 & 800 & 800\end{array}$

TOP L6

BOTT L6

$\begin{array}{llllll}803 & 805 & 805 & 800 & 795 & 795\end{array}$

$\begin{array}{llllll}815 & 815 & 810 & 811 & 812 & 813\end{array}$

$\begin{array}{lllllll}805 & 806 & 802 & 798 & 799 & 799\end{array}$

$\begin{array}{llllll}795 & 790 & 790 & 790 & 790 & 790\end{array}$

TOP L7

$\begin{array}{llllll}98 & 800 & 800 & 795 & 790 & 790\end{array}$

$\begin{array}{llllll}810 & 810 & 805 & 806 & 807 & 808\end{array}$

$\begin{array}{lllllll}800 & 801 & 797 & 793 & 794 & 794\end{array}$

$\begin{array}{llllll}790 & 785 & 785 & 785 & 785 & 785\end{array}$

15

1.0

(20F4.0)

1

BOTT L7

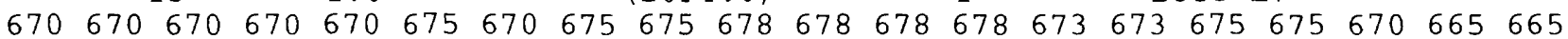

$\begin{array}{lllllllllllllllllllll}665 & 665 & 665 & 665 & 665 & 665 & 670 & 670 & 680 & 680 & 680 & 680 & 680 & 680 & 685 & 685 & 680 & 681 & 682 & 683\end{array}$

$\begin{array}{llllllllllllllllllll}683 & 684 & 684 & 685 & 686 & 682 & 682 & 683 & 683 & 683 & 684 & 674 & 675 & 675 & 675 & 676 & 672 & 668 & 669 & 669\end{array}$

$\begin{array}{llllllllllllllllllll}669 & 669 & 669 & 669 & 669 & 669 & 669 & 669 & 669 & 669 & 669 & 669 & 665 & 665 & 665 & 660 & 660 & 660 & 660 & 660\end{array}$

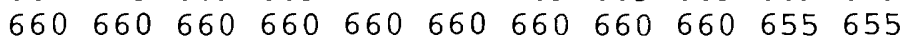
15
1.0
(20F4.0)
1
TOP L8

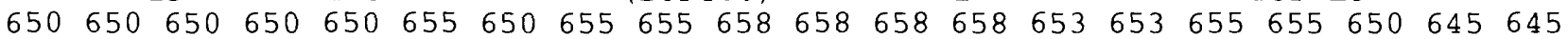

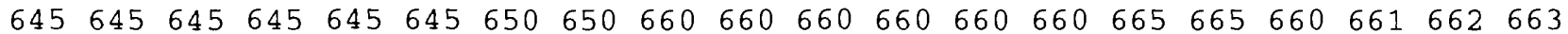

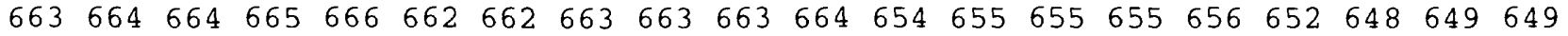

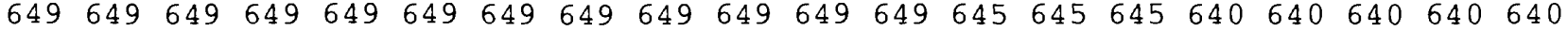
$640 \quad 640 \quad 640 \quad 640 \quad 640 \quad 640 \quad 640 \quad 640 \quad 640 \quad 635 \quad 635$
15
1.0
(20F4.0)
1
BOTT L8

$\begin{array}{llllllllllllllllllll}610 & 610 & 610 & 610 & 610 & 615 & 610 & 615 & 615 & 618 & 618 & 618 & 618 & 613 & 613 & 615 & 615 & 610 & 605 & 605\end{array}$

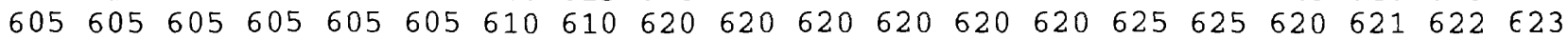
$\begin{array}{llllllllllllllllllll}623 & 624 & 624 & 625 & 626 & 622 & 622 & 623 & 623 & 623 & 624 & 614 & 615 & 615 & 615 & 616 & 612 & 608 & 609 & 609\end{array}$ $609609609609609609609609609609609609605605 \quad 605 \quad 600600600600600$ $600600600600600600600600600 \quad 595 \quad 595$ 
Listing 6. Input values for the main data file of the particle-tracking post-processing program--Continued

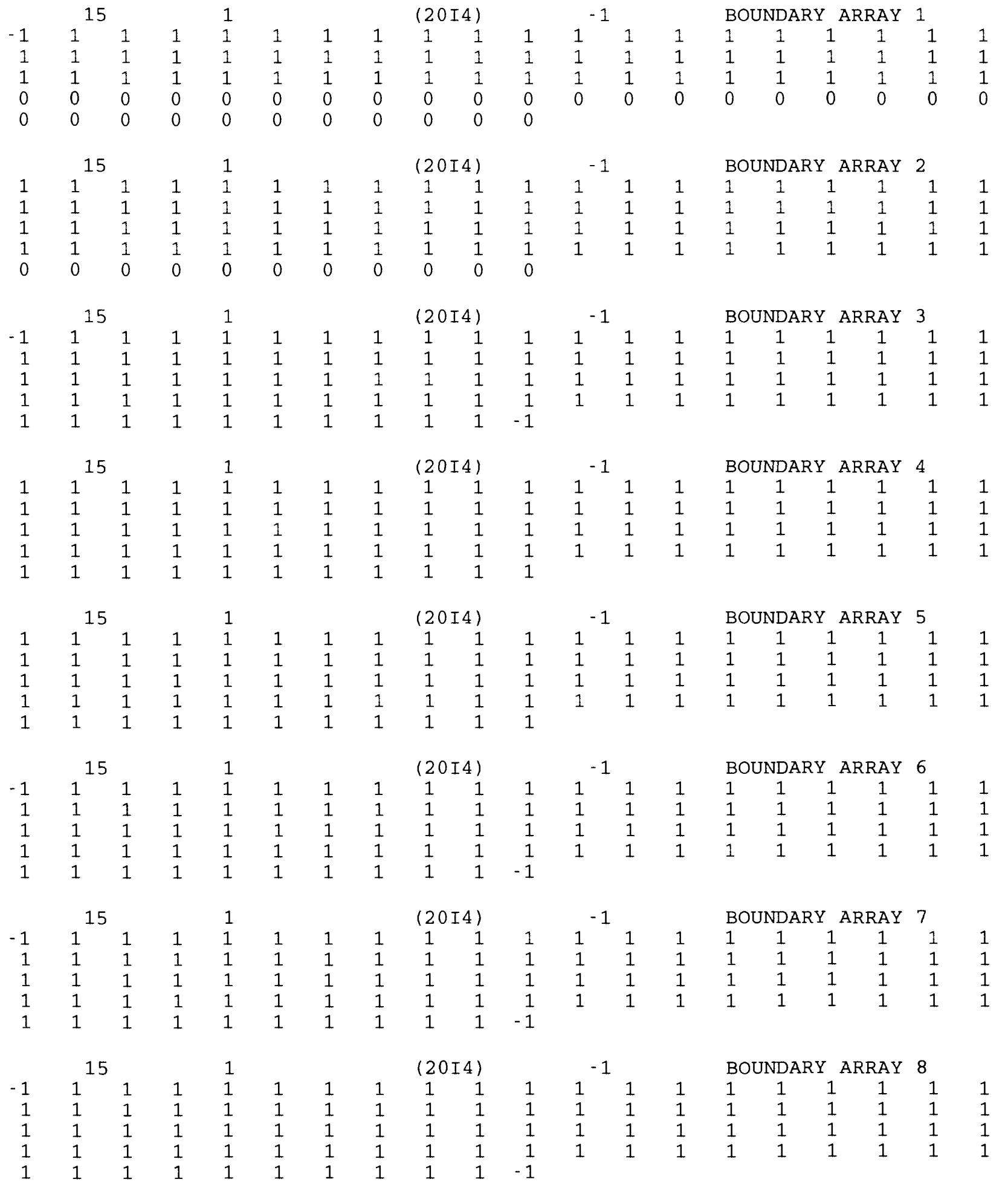


Listing 6. Input values for the main data file of the particle-tracking post-processing program--Contin 'led

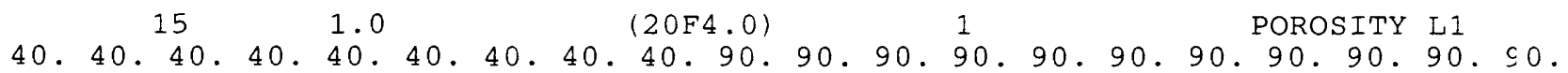
90.90.40.40.40.40.40.40.40.40.40.40.40.40.40.40.40.40.40.40. 40.40.40.40.40.40.40.40.40.40.40.40.40.40.40.40.40.40.40.40. $\begin{array}{llllllllllllllllllll}0 & 0 & 0 & 0 & 0 & 0 & 0 & 0 & 0 & 0 & 0 & 0 & 0 & 0 & 0 & 0 & 0 & 0 & 0 & 0\end{array}$ $15 \quad 1.0 \quad(20 \mathrm{~F} 4.0) \quad 1 \quad$ POROSITY L2

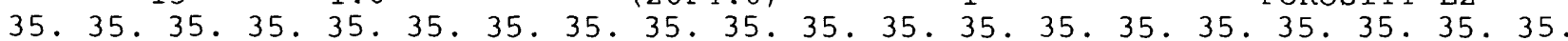
$35.35,35,35,35,35,35,35,35,35,35,35,35,35,35,35,35,35,35,35$.

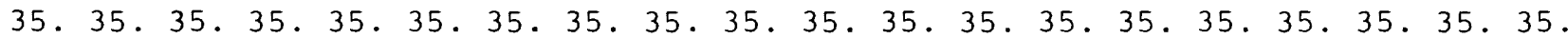
$35.35 \cdot 35 \cdot 35 \cdot 35 \cdot 35 \cdot 35 \cdot 35 \cdot 35 \cdot 35 \cdot 35 \cdot 35 \cdot 35 \cdot 35 \cdot 35 \cdot 35 \cdot 35 \cdot 35 \cdot 35 \cdot 35$. $\begin{array}{lllllllllll}0 & 0 & 0 & 0 & 0 & 0 & 0 & 0 & 0 & 0 & 0\end{array}$

$15 \quad 1.0 \quad(20 \mathrm{~F} 4.0)$ $1 \quad$ POROSITY L3 40. 40. 40.40.40.40.40.40.40.40.40,40.40.40.40.40.40.40.40.40.

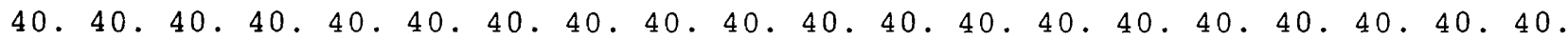
40.40.40.40.40.40.40.40.40.40.40,40,40.40.40.40,40.40.40.40. 40.40.40.40.40.40.40.40.40.40.40.40.40.40.40.40.40.40.40.40. $40.40 .40 .40,40.40 .40 .40 .40 .40 .40$.

\section{$15 \quad 1.0 \quad(20 \mathrm{~F} 4.0) \quad 1 \quad$ POROSITY L4}

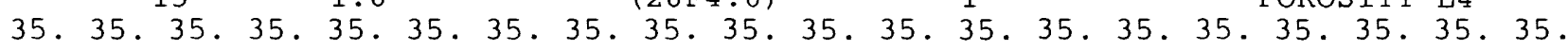

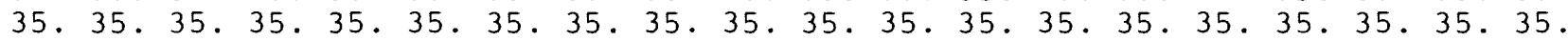

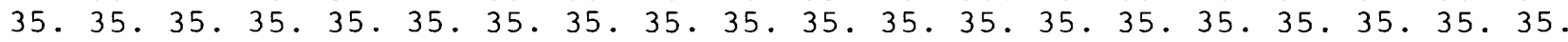

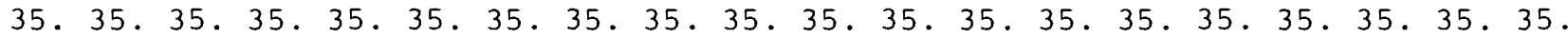
$35.35,35,35,35.35,35.35,35.35,35$.

$15 \quad 1.0 \quad(20 \mathrm{~F} 4.0) \quad 1 \quad$ POROSITY L5

35. 35. 35. 35. 35. 40.40.40.40.40.40.40.40.40.40.40.40.40.40.40. 40. 32. 32, 32, 32, 32, 32, 32, 32, 32, 32, 32, 32, 32, 32, 32, 32, 32, 32. 32. $32.32,32,32,32,32,32,32,32,32,32,32,32,32,32,32,32,32 \cdot 32,32$. $32.32,35,35,35,35,35,35,35,35,35,35,32,32,32,32,32,32,32,32$. 32. $32,32,32,32,32,32,32,32,32,32$.

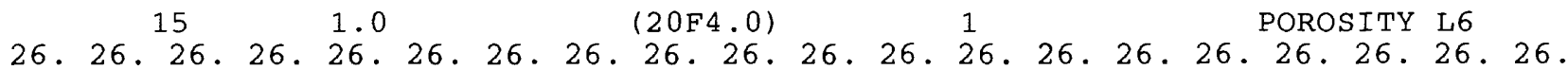

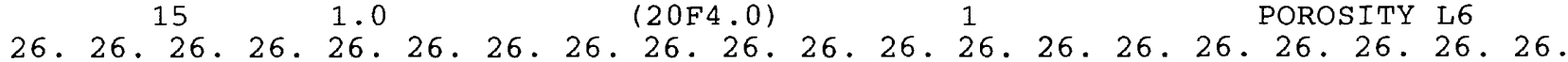
26. 26. 26, 26, 26, 26, 26, 26, 26, 26, 26, 26, 26, 26, 26, 26, 26, 26, 26, 26 .

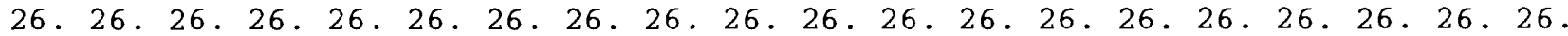

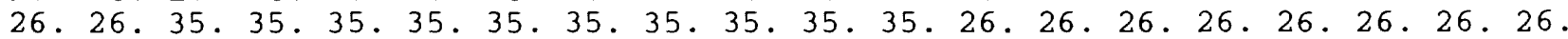
26. 26, 26, 26, 26, 26, 26, 26, 26, 26, 26.

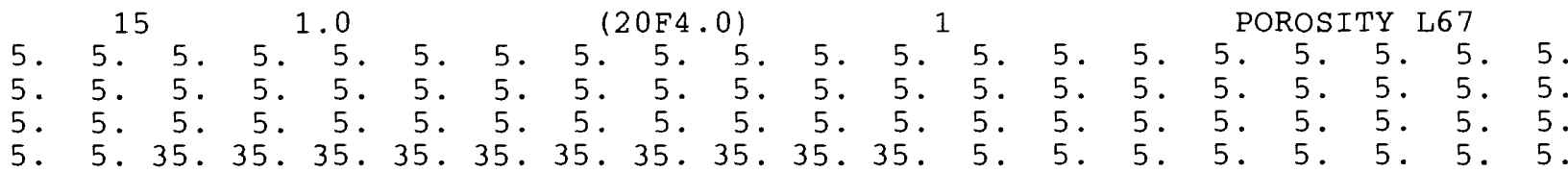

$$
\begin{aligned}
& \text { 5. 5. 5. 5. 5. 5. 5. 5. 5. 5. } 5 \text {. } \\
& \begin{array}{lr}
0 & 25 . \\
0 & 5 . \\
0 & 31 .
\end{array}
\end{aligned}
$$

